Roberto Biava Júnior

\title{
AS FUNÇÕES DA CONTABILIDADE NO ICMS \\ BRASILEIRO: os impactos da convergência às normas contábeis internacionais e do projeto SPED - Sistema Público de Escrituração Digital.
}

\author{
Tese de Doutorado \\ Orientador: Prof. Associado Dr. Gerd Willi Rothmann
}

UNIVERSIDADE DE SÃO PAULO

FACULDADE DE DIREITO

São Paulo - SP 
Roberto Biava Júnior

\section{AS FUNÇÕES DA CONTABILIDADE NO ICMS \\ BRASILEIRO: os impactos da convergência às normas contábeis internacionais e do projeto SPED - Sistema Público de Escrituração Digital.}

Tese apresentada à Banca Examinadora do Programa de Pós-Graduação em Direito, da Faculdade de Direito da Universidade de São Paulo, como exigência parcial para obtenção do título de Doutor em Direito, na área de concentração do Departamento de Direito Econômico, Financeiro e Tributário - DEF, sob orientação do Prof. Associado Dr. Gerd Willi Rothmann.

UNIVERSIDADE DE SÃO PAULO

FACULDADE DE DIREITO

São Paulo - SP 
Autorizo a reprodução e divulgação total ou parcial deste trabalho, por qualquer meio convencional ou eletrônico, para fins de estudo e pesquisa, desde que citada a fonte.

Biava Júnior, Roberto
As Funçōes da Contabilidade no ICMS Brasileiro: os impactos da convergência às normas contábeis internacionais e do projeto SPED - Sistema Público de Escrituração Digital / Roberto Biava Júnior ; orientador Gerd Willi Rothmann -- São Paulo, 2017. $385 \mathrm{f}$.

Tese (Doutorado - Programa de Pós-Graduação em Direito Direito Econômico, Financeiro e Tributário) Faculdade de Direito, Universidade de São Paulo, 2017 .

1. DIREITO TRIBUTÁRIO. 2. IMPOSTO SOBRE CIRCULAÇÃO DE MERCADORIAS E SERVIÇOS. 3. CONTABILIDADE TRIBUTÁRIA. 4. CONTABILIDADE SOCIETÁRIA. 5. FISCALIZAÇÃO TRIBUTÁRIA. I. Rothmann, Gerd Willi, orient. II. Titulo. 
Roberto Biava Júnior

\section{AS FUNÇÕES DA CONTABILIDADE NO ICMS \\ BRASILEIRO: os impactos da convergência às normas contábeis internacionais e do projeto SPED - Sistema \\ Público de Escrituração Digital.}

Tese apresentada ao Programa de PósGraduação em Direito no Departamento de Direito Econômico, Financeiro e Tributário DEF da Universidade de São Paulo para a obtenção do título de Doutor em Direito.

Aprovado em: /2.017.

BANCA EXAMINADORA

Docente - Universidade de São Paulo (FD/USP)

Docente - Universidade de São Paulo (FD/USP)

Docente - Universidade de São Paulo (FD/USP) 
À minha namorada Cláudia, a meus pais Roberto e Sílvia, e à minha irmã Érika, que de muitas formas me incentivaram para que fosse possível a concretização deste trabalho. 


\section{AGRADECIMENTOS}

Aos meus pais, Roberto e Sílvia, pela formação moral e afetiva que me proporcionaram. À minha irmã Érika pela afeição, carinho e motivação.

À minha namorada Cláudia Denise pelo carinho, apoio e compreensão, nos momentos em que tive que abrir mão do convívio para me dedicar ao Doutorado.

Aos colegas de trabalho da Secretaria da Fazenda por estes 10 anos de convivência produtiva na seara do ICMS, o que me tem permitido me manter sempre motivado na labuta desta área tributária. Aos colegas e alunos do Centro Universitário SENAC-SP pelo convívio motivador destes últimos 3 anos.

Agradeço à equipe da Consultoria Tributária e do Tribunal de Impostos de Taxas pelo conhecimento compartilhado que me têm proporcionado e também pela compreensão (afinal de contas foram três meses de férias/licença para dar cabo da finalização desta tese).

Um agradecimento muito especial à Equipe de trabalho do Projeto PROFISCO 4.8 e aos Professores da FUNDACE de Ribeirão Preto, cujos debates e vivência nos últimos anos me motivaram a escrever o presente trabalho. Sem esta vivência este trabalho não existiria!

Ao nosso orientador, Professor Gerd Rothmann, o qual me acolheu na monitoria de Direito Tributário da graduação desta Faculdade de Direito na época em que fiz o mestrado com o saudoso Professor Alcides Jorge Costa, e que nos deu a felicidade de nos aceitar para esta empreitada doutoral.

Aos Professores do Programa de Pós-Graduação em Direito da Universidade de São Paulo, pela motivação acadêmica constante, e pela busca pela verdadeira Justiça Tributária. 
“TEU TRABALHOO teu trabalho é o cântico

De tua própria vida. Imprime nele onde estiveres

A nota azul de teu amor.

Estuda a Natureza:

Age o vento compondo melodias. O rio mostra a força e convida ao serviço

$\mathrm{Na}$ cachoeira a estrondear. Não busques a tarefa que te cabe Com a tristeza do escravo. O teu trabalho é a oficina Em que podes forjar a tua própria luz."

Emmanuel

Francisco Cândido Xavier e Carlos Bacceli, Crer e Agir. 


\section{RESUMO}

BIAVA JÚNIOR, Roberto. As funções da contabilidade no ICMS brasileiro: os impactos da convergência às normas contábeis internacionais e do projeto SPED Sistema Público de Escrituração Digital. 2017. 385 f. Tese (Doutorado em Direito Econômico, Financeiro e Tributário) - Faculdade de Direito, Universidade de São Paulo, São Paulo, 2017.

O presente trabalho (adotando os métodos de pesquisa tradicionais da área jurídica como pesquisa bibliográfica de doutrina com posições dialéticas, de jurisprudência, e análise crítica interpretativa de legislação tributária) visa analisar as funções da contabilidade para fins do direito tributário em relação ao principal tributo sobre o consumo brasileiro (ICMS) sobre duas acepções principais: a) a utilização da contabilidade (na acepção de escrita contábil - demonstrações financeiras e livros comerciais das empresas) como obrigação acessória ao cumprimento da obrigação tributária do imposto no âmbito do projeto SPED-Sistema Público de Escrituração Digital, analisando-se sob o enfoque do ICMS questões jurídicas e contábeis fundamentais relacionadas ao tema da informatização da entrega de informações contábeis e fiscais (SPED) à administração tributária (principal usuário da informação), especialmente em relação à administração de riscos fiscais e custos de conformidade tributária por parte das empresas, e os possíveis impactos do projeto SPED no tradicional instituto jurídico do lançamento tributário; b) a possibilidade de utilização da contabilidade (conceitos e institutos constantes das normas contábeis, que integram o direito privado) pelo legislador tributário como elemento integrante da regra matriz de incidência tributária dos tributos, em geral; analisando-se, especificamente, os efeitos tributários no ICMS da convergência da contabilidade brasileira para o padrão internacional (IFRS) e que podem impactar as entidades empresariais e os Fiscos estaduais.

Frise-se que neste campo de pesquisa (da inter-relação da contabilidade com o direito tributário) tradicionalmente a maior parte dos trabalhos se foca na tributação da renda (IRPJ/CSLL) e quando tratam da tributação do consumo se atém às contribuições federais PIS e COFINS. Desta forma, as conclusões apresentam requisitos de originalidade com contribuições ao Fisco Estadual e às empresas, no que concerne à análise dos efeitos tributários no ICMS, bem como de recomendações de aperfeiçoamento legislativo em face destas duas revoluções contemporâneas que afetam a tributação e também o ICMS (o impacto do novo padrão contábil internacional -IFRS- e o advento das informações contábeis e fiscais informatizadas por meio do instrumento do SPED).

Palavras-Chave: Direito Tributário; Convergência às Normas Internacionais de Contabilidade; IFRS; ICMS; Tributação sobre o Consumo; Imposto sobre o valor agregado. 


\begin{abstract}
BIAVA JÚNIOR, Roberto. The function of accounting in the context of the brazilian ICMS tax: the impact of the convergence of international accounting standards and the Public Digital Book-Entry System - SPED. 2017. 385 f. Tese (Doutorado em Direito Econômico, Financeiro e Tributário) - Faculdade de Direito, Universidade de São Paulo, São Paulo, 2017.
\end{abstract}

The objective of this study (which adopts traditional research methods in the legal field, including bibliographic searches of the legal scholarship arguing different positions, the case law, and critical interpretive analyses of the applicable tax laws) is to analyze the function of accounting in the realm of tax law in relation to the principal Brazilian consumption tax (ICMS - Tax on the Circulation of Goods and Transportation and Communication Services) from two main perspectives: a) use of accounting (with regard to accounting records - corporate financial statements and commercial books) as an accessory obligation to full performance of tax obligations under the Public Digital BookEntry System (Sistema Público de Escrituração Digital - SPED), analyzing, to this end, fundamental legal and accounting issues in the context of the ICMS tax relating to the automation of accounting and tax information deliveries (SPED) to the jurisdictional tax authorities (primary user of the related information), particularly with respect to management of tax risks and the costs of tax compliance for companies and the potential impacts of the SPED project on the traditional legal tax entry system; b) the possibility of using accounting (concepts and mechanisms prescribed in the pertinent accounting standards incorporated under private law) in the applicable tax legislation as a foundational component of tax assessment in general; specifically examining, in this light, the resulting tax effects, within the context of the ICMS, of the convergence of Brazilian accounting practices and the prevailing international standard (International Financial Reporting Standards - IFRS) and the potential of this convergence to impact business entities and state Tax Authorities.

Note that in this particular field of study (of the interrelationship between accounting and tax law) the majority of studies have traditionally focused on income taxes (IRPJ/CSLL - Individual Income Tax/Social Contribution on Net Profits). Indeed, to the extent the literature has examined taxes on consumption the focus has invariably been on the two principal federal contributions - PIS (Social Integration Program Contribution) and COFINS (Social Security Financing Contribution). As such, the conclusions set out in these pages offer an original contribution to State Tax Authorities and companies in regard to the analysis of the tax effects of the ICMS, in addition to recommendations for enhancing the applicable laws in the light of the two contemporary revolutions currently sweeping the taxation system and the ICMS as well (namely, the impact of the new international accounting standard - IFRS - and the advent of computerized accounting and tax information through the SPED)..

Keywords: Tax Law; Convergence with International Accounting Standards; IFRS; ICMS; Consumption Taxes; Value-Added Taxes. 


\section{RÉSUMÉ}

BIAVA JÚNIOR, Roberto. Les fonctions de la comptabilité en ce qui concerne L'ICMS brésilien: les impacts de la convergence vers les normes comptables internationales et du projet SPED - Système Public d'Écriture Numérique. 2017. 385 f. Tese (Doutorado em Direito Econômico, Financeiro e Tributário) - Faculdade de Direito, Universidade de São Paulo, São Paulo, 2017.

Le présent travail (adoptant les méthodes de recherche traditionnelles dans le domaine juridique telles que la recherche bibliographique de doctrine avec des positions dialectiques, de jurisprudence, et analyse critique interprétative de la législation fiscale) vise analyser les fonctions de la comptabilité aux effets du droit fiscal par rapport au principal impôt brésilien sur la consommation (ICMS) sous deux perspectives majeures a) l'utilisation de la comptabilité (dans le sens d'écriture comptable - états financiers et registres commerciaux des sociétés) en tant qu'obligation accessoire à l'accomplissement de l'obligation fiscale de l'impôt dans le cadre du projet SPED - Système Public d'Écriture Numérique, analysant sous le prisme de l'ICMS des questions juridiques et comptables ayant trait au thème de l'informatisation de la remise d'informations comptables et fiscales (SPED) à l'Administration fiscale (principal utilisateur de l'information), notamment en ce qui concerne la gestion des risques fiscaux et des coûts de conformité fiscale de la part des sociétés, et les possibles impacts du projet SPED sur l'institution juridiquedu recouvrement fiscal; b) la possibilité d'utilisation de la comptabilité (concepts et règles figurant sur les normes comptables, qui intègrent le droit privé) par le législateur fiscal en tant qu'élément intégrant de la règle matrice de l'incidence fiscale des impôts, en général ; en analysant, spécifiquement, les effets fiscauxsur l'ICMS de la convergence de la comptabilité brésilienne vers les normes internationales (IFRS) et qui peuvent avoir un impact sur les entités entrepreneuriales et le Fisc des États.

Il faut souligner que dans ce domaine de recherche (l'interrelation de la comptabilité avec le droit fiscal) la plupart des travaux e vise traditionnellement l'impôt sur le revenu (IRPJ/CSLL) et lorsqu'ils se réfèrent à l'imposition sur la consommation, ils se limitent aux impôts fédéraux PIS et COFINS. Ainsi, les conclusions présentent les aspects requis d'originalité avec les contributions au Fisc des États et aux sociétés, en ce qui concerne l'analyse des effets fiscaux sur le ICMS (l'impact des nouvelles règles comptables internationales - IFRS - et l'avènement des informations comptables et fiscales informatisées au moyen de l'instrument du SPED).

Mots-Clés: Droit Fiscal; Convergence vers les Normes Internationales de Comptabilité; IFRS, ICMS; Imposition sur la Consommation ; Impôt sur la valeur ajoutée. 


\section{SUMÁRIO}

LISTA DE ABREVIATURAS E SIGLAS.

LISTA DE FIGURAS. .23

LISTA DE QUADROS E TABELAS. .24

Capítulo 1 - INTRODUÇÃO. .25

1.1 Delimitação do tema a ser desenvolvido e limitações da pesquisa. ..26

1.2 Justificativa da escolha, da importância e originalidade do tema.......31

1.3 Principais questões a serem analisadas sobre o tema..............................34

1.4 Metodologia utilizada na pesquisa.

\section{PARTE A - BASE TEÓRICA PROPEDÊUTICA: O NOVO PADRÃO} CONTÁBIL INTERNACIONAL E O ICMS.

\section{Capítulo 2 - CONVERGÊNCIA DA CONTABILIDADE BRASILEIRA ÀS NORMAS CONTÁBEIS EM PADRÃO INTERNACIONAL (IFRS).}

2.1 Introdução - Nova contabilidade brasileira: a convergência contábil internacional ao Novo Padrão Contábil Internacional (IFRS)......47

2.2 A diversidade de padrões contábeis e os vários enfoques da contabilidade. A necessidade da adoção de um padrão contábil internacional no Brasil e a adoção do IFRS.

2.3 A juridicidade das normas jurídico-contábeis emanadas pelo Comitê de Pronunciamento Contábeis - CPC no Brasil.

2.4 Características do Novo Padrão Contábil Internacional (IFRS) adotado no Brasil (CPCs): a adoção do Princípio da Essência econômica sobre a Forma jurídica; maior importância aos conceitos de controle, de obtenção de benefícios e de incorrência em riscos do que ao de propriedade jurídica; Accrual system; Normas contábeis baseadas em Princípios; Responsabilidade da Empresa como "um todo" pela informação contábil. 
2.5 Relação do Direito Tributário com as Normas Contábeis. O modelo brasileiro de Relação Direito Tributário e Normas Contábeis (antes e após a convergência contábil internacional).

2.5.1 Neutralidade Tributária, Regime Tributário de Transição - RTT e a tentativa "fracassada" de se promover a completa "desconexão" entre as normas tributárias e as normas contábeis no Brasil.

2.5.2 O modelo brasileiro atual de Relação Direito Tributário e Normas Contábeis (pós Lei no 12.973/2014): o retorno ao modelo da dependência parcial.

\section{Capítulo 3 - 0 ICMS BRASILEIRO (ASPECTOS JURÍDICOS E CONTÁBEIS)}

3.1 Contornos gerais do ICMS brasileiro. .75

3.1.1 ICMS brasileiro: imposto sobre valor acrescido; calculado pelo método imposto sobre imposto; com forma de cálculo tipo produto bruto e parcialmente tipo consumo.

3.1.2 ICMS brasileiro: imposto não-cumulativo, pago fracionadamente; que preponderantemente adota o critério do crédito físico e parcialmente o financeiro.

3.1.3 ICMS brasileiro: imposto com generalidade vertical: abrangendo ciclo da produção e da comercialização até entrega das mercadorias ao consumidor final.

3.1.4 ICMS brasileiro: imposto com generalidade no plano horizontal que não abrange os imóveis, nem os serviços, exceto os de transporte e de comunicação; e que adota o princípio do país do destino conforme a Constituição Federal de 1988. 
3.1.5 ICMS brasileiro: adota regras ou mecanismos de regularização (regra de reversão, a regra "pro rata", e regra do teto) e não tributa o "auto-consumo" interno e externo. 94

3.2 Substituição Tributária no ICMS: noções gerais e finalidades deste tipo de tributação monofásica.

3.3 Contabilização do ICMS - Substituição Tributária versus ICMS na Sistemática RPA - Normal.

3.4 O substrato econômico da hipótese de incidência da RMIT do ICMS: operações relativas à circulação de mercadorias. 108

3.5 O princípio da autonomia dos estabelecimentos no ICMS. 113

3.6 Peculiaridades da Contabilização do imposto sobre o consumo brasileiro ICMS em contraponto às contribuições federais (PISCOFINS): hipótese de incidência de conteúdo econômico (operações relativas à circulação de mercadoria) aplicada no contexto da "autonomia" dos estabelecimento.

PARTE B - AS FUNÇÕES DA CONTABILIDADE NO ICMS BRASILEIRO - OS IMPACTOS DA CONVERGÊNCIA ÀS NORMAS CONTÁBEIS INTERNACIONAIS E DO PROJETO SPED - SISTEMA PÚBLICO DE ESCRITURAÇÃO DIGITAL.

Capítulo 4 - 0 PROJeto SPED - Sistema PÚBlico DE ESCRITURAÇÃO DIGITAL: a utilização DA contabilidade/ (escrituração contábil) como obrigação acessória ao cumprimento da obrigação tributária NO ICMS............................................121

4.1 Os Fiscos como usuários relevantes da informação contábil do SPED-ECD (especialmente no Brasil) sob a abordagem da teoria contratual da firma. 
4.2 O contexto moderno das obrigações acessórias (ou dos deveres instrumentais) informatizadas(os).

4.3 A Nota Fiscal Eletrônica -NF-e como o subprojeto "embrião" do SPED.

4.4 O projeto SPED e as escriturações contábeis (ECD) e fiscais (EFD).133 4.4.1 O SPED contábil (ECD). 138

4.4.2 O SPED fiscal (EFD). 141

4.4.3 O SPED fiscal (outras etapas). 144

4.4.4 O SPED fiscal (outras etapas) - Perspectiva para a substituição da GIA-ICMS.

4.5 Os impactos do SPED em relação aos Custos de Conformidade Tributária (para administração tributária e contribuintes) e a administração de Riscos Fiscais pelas empresas contribuintes.

4.5.1 O SPED e os custos de conformidade para a Administração Tributária e para os contribuintes.

4.5.2 O SPED e a administração de riscos fiscais pelas empresas contribuintes.

4.5.3 Irregularidades contábeis na escrita comercial que podem acarretar a autuação por presunção de omissão de operações tributáveis pelo ICMS (artigos 509 e 509-A do RICMS/SP)

4.6 A informatização das informações contábeis e fiscais (SPED) e seus possíveis impactos no instituto jurídico do lançamento tributário.165 4.7 Normas Contábeis de "Disclosure" das Subvenções e Assistências governamentais: como instrumento de combate à "Guerra Fiscal" no ICMS

4.8. Reconhecimento Contábil da Receita de vendas de mercadorias em situações de dessincronização com o fato gerador do ICMS (exemplo dos ativos biológicos).

Capítulo 5 - Consideração econômica, juridicidade das normas contábeis no direito privado e positivação de conceitos contábeis 
5.1 Consideração econômica, e a positivação na legislação tributária de conceitos econômico-contábeis.

5.2 A Classificação dos Tributos - critérios jurídicos, econômicos e contábeis.

5.2.1 Dois exemplos da utilização de critérios classificatórios contábeis e econômicos pelo legislador tributário - a Restituição do Indébito tributário nos tributos indiretos (CTN) e a inclusão do ICMS na Base de Cálculo do PIS-COFINS.

5.2.2 A clássica Classificação Jurídica dos Tributos pelas espécies tributárias e a necessidade ou não de um critério extrínseco (destino do produto da arrecadação).

5.2.3 Exemplo - a invasão "econômica" da União na Competência Tributária constitucional dos Estados e Municípios e a ofensa ao pacto federativo - o exemplo das contribuições do PIS-COFINS (bitributação econômica e contábil das mercadorias e serviços).

5.3. A Consideração (Interpretação) Econômica e a classificação dos tributos incidentes sobre atos-fatos "formais" ou "econômicos".

5.3.1 Consideração (Interpretação) Econômica: da possibilidade da "interpretação econômica" em relação aos tributos com materialidade (fato gerador /hipótese de incidência) embasada em conceitos econômicos e/ou contábeis - Os Exemplos do ICMS e do IRPJ.

5.4 Conclusões quanto à Classificação Tributária, a Consideração (Interpretação) Econômica nos principais tributos do Brasil e a Possibilidade de positivação na legislação tributária de conceitos econômico-contábeis.

5.5 Regras Contábeis como Normas Jurídicas e a sua relação com o Direito Tributário.

5.5.1 Normas Jurídico-Contábeis de Direito Privado (com conteúdo cada vez mais econômico) podem ser utilizadas pelo Legislador Tributário.

5.5.2 Relação das Normas Contábeis (de Direito Privado) com as Normas Tributárias: sob o enfoque dos artigos 109 e 110 do CTN. 
5.6 A regra-matriz de incidência dos tributos e a possibilidade de inserção de elementos contábeis.

5.7 A positivação de conceitos contábeis na regra-matriz de incidência dos tributos: quando o conceito contábil for captado pelo direito tributário (como elemento integrante do fato gerador/hipótese de incidência do tributo; ou, como elemento quantitativo da base de cálculo do tributo, quando a legislação tributária elege um elemento quantitativo mensurado pela contabilidade).

5.7.1 Exemplos de conceitos contábeis na Regra Matriz de Incidência do IRPJ. .238

5.7.2 Exemplos de conceitos contábeis na Regra Matriz de Incidência do PIS/COFINS.

5.7.3 Exemplos de conceitos contábeis na Regra Matriz de Incidência do ICMS.

\section{CAPÍTULO 6 - PRÁTICA E PRAGMÁTICA TRIBUTÁRIA - IFRS QUE}

SE RELACIONAM COM AS QUESTÕES PRÁtICAS DO ICMS. ANÁLISE dOS EFEITOS TRIBUTÁRIOS DA NOVA CONTABILIDADE BRASILEIRA (PADRÃO INTERNACIONAL) NO ICMS.

6.1. O processo de convergência contábil internacional e sua relevância para a Administração Tributária Estadual.

6.2 Análise dos Efeitos Tributários da Nova Contabilidade Brasileira (Padrão Internacional) no ICMS: principais situações práticas.

6.2.1. O Valor Realizável Liquido (VRL) dos Estoques e a Base de Cálculo do ICMS em situações específicas.

6.2.2. Mensuração dos estoques e a base de cálculo do ICMS nas transferências (e recebimentos) de mercadoria para (de) outra unidade da federação. 
6.2.3. Mensuração da Receita, apuração do Ajuste a valor presente (AVP) e a Base de Cálculo do ICMS nas vendas a prazo.............................276

6.2.4. Ativo Imobilizado nas Concessões..........................................................283

6.2.5. Arrendamento Mercantil Operacional. .................................................287

6.3. Reconhecimento e Mensuração do Ativo Imobilizado - Diversas situações.

6.3.1 Reconhecimento e Mensuração do Ativo Imobilizado - Reposição do Ativo Imobilizado (Peças e Partes) e o Creditamento do ICMS (item $8)$. 300

6.3.2 Reconhecimento e Mensuração do Ativo Imobilizado - Prazo para o Creditamento do ICMS do Ativo Imobilizado (item 9).

6.3.3 Reconhecimento e Mensuração do Ativo Imobilizado - Início do Creditamento do ICMS do Ativo Imobilizado (item 10).

6.3.4 Reconhecimento e Mensuração do Ativo Imobilizado - Bens (Ativo Imobilizado) em poder de terceiros e o creditamento do ICMS (item 11).

6.3.5 Reconhecimento e Mensuração do Ativo Imobilizado - Crédito de Ativo Imobilizado para construção de um bem imóvel (item 12)......320 6.3.6 Reconhecimento e Mensuração do Ativo Imobilizado e de Receitas de Vendas de mercadorias - Descaracterização de contratos como Locação, Aluguel, Comodato e Figuras Análogas. (item 13).

PARTE C - CONCLUSÕES DA TESE

Capítulo 7 - Conclusões e teses.

REFERÊNCIAS BIBLIOGRÁFICAS

APÊNDICE: Quadro de Riscos Fiscais dos Impactos Tributários da Nova Contabilidade (padrão internacional) no ICMS. 


\section{LISTA DE ABREVIATURAS E SIGLAS.}

ANBIMA Associação Brasileira das Entidades dos Mercados Financeiro e de Capitais ABRASCA Associação Brasileira das Companhias Abertas

ANATEL Agência Nacional de Telecomunicações

ANEEL Agência Nacional de Energia Elétrica

ANP

Agência nacional do Petróleo

ANS

Agência Nacional de Saúde Suplementar

AVP

Ajuste a valor presente

BACEN Banco Central do Brasil

BR GAAP Brazilian Generally Accepted Accounting Principles

ECD Escrituração Contábil Digital

EFD Escrituração Fiscal Digital

E-LALUR Livro Eletrônico de Escrituração e Apuração do Imposto sobre Renda e da Contribuição Social sobre o Lucro Líquido da Pessoa Jurídica

CAT Coordenadoria da Administração Tributária

CCB Código Civil Brasileiro

CFC Conselho Federal de Contabilidade

CMV Custo da Mercadoria Vendida

CNI Confederação Nacional da Indústria

COFINS Contribuição para Financiamento da Seguridade Social

CONFAZ Conselho Nacional de Política Fazendária

CPC Comitê de Pronunciamentos Contábeis (brasileiro)

CSLL Contribuição Social sobre o Lucro Líquido

CT-e Conhecimento de Transporte Eletrônico

CTN Código Tributário Nacional

CVM Comissão de Valores Mobiliários

DNRC Departamento Nacional de Registro de Comércio

DRE Demonstração do Resultado do Exercício

ENCAT Encontro Nacional de Coordenadores e Administradores Tributários

Estaduais

FASB Financial Account Standards Board

FEBRABAN Federação Brasileira de Bancos 
FENACON Federação Nacional das Empresas de Serviços Contábeis e das Empresas de Assessoramento, Perícias, Informações e Pesquisas

FENAINF Federação Nacional das Empresas de Serviços Técnicos de Informática e Similares

FIPECAFI Fundação Instituto de Pesquisas Contábeis, Atuariais e Financeiras

GIA-ICMS Guia de Informação e Apuração do ICMS

IASB International Accounting Standards Board

IBRACON Instituto de Auditores Independentes do Brasil

ICMS Imposto sobre operações relativas à circulação de mercadorias e sobre prestações de serviços de transporte interestadual e intermunicipal e de comunicação

ICMS-ST ICMS sobre a operação sujeita à Substituição Tributária

IFRS International Financial Reporting Standards

IPECAFI Instituto Brasileiro de Pesquisas Contábeis

IPI Imposto sobre Produtos Industrializados

IRPJ Imposto de Renda Pessoa Jurídica

ISS Imposto sobre Serviços

ITBI Imposto sobre Transmissão de Bens Imóveis

ITCMD Imposto sobre Transmissão Causa Mortis e Doação de Quaisquer Bens ou

Direitos

IVA Imposto sobre Valor Agregado

IVC Imposto sobre Vendas e Consignações

LALUR Livro de Apuração do Lucro Real

MDF-e Manifesto Eletrônico de Documentos Fiscais

NF-e Nota Fiscal Eletrônica

NFS-e Nota Fiscal de Serviços Eletrônica

PIS Programa de Integração Social

RFB Receita Federal do Brasil

RICMS/SP Regulamento do ICMS no Estado de São Paulo

RMIT Regra Matriz de Incidência Tributária

RPA Regime Periódico de Apuração

RTT Regime Tributário de Transição

SERPRO Serviço Federal de Processamento de Dados

SINTEGRA Sistema Integrado de Informações sobre Operações Interestaduais de Mercadorias e Serviços 
SPC Secretaria de Previdência Complementar

SPED Sistema Público de Escrituração Digital

STF Supremo Tribunal Federal

STJ Superior Tribunal de Justiça

SUSEP Superintendência de Seguros Privados

TIT-SP Tribunal de Impostos e Taxas do Estado de São Paulo

UEPS Último que Entra, Primeiro que Sai

US GAAP Generally Accepted Accounting Principles in the United States

VRL Valor Realizável Líquido 


\section{LISTA DE FIGURAS}

Figura 1.1 - Funções da Contabilidade para o Direito Tributário (objeto da tese) 27

Figura 1.2 - Funções do Direito Tributário para a Contabilidade (que não integra o objeto da tese - limitações do estudo) 30

Figura 1.3 - Funções do Direito Tributário e da Contabilidade para o Desenvolvimento Econômico (que não integra o objeto da tese - limitações do estudo). .31

Figura 2.1 - Classificação Dual dos Padrões Contábeis entre os Países........................................51

Figura 3.1: Substituição Tributária - venda da indústria para o atacadista, com base de cálculo ST (Preço de venda previsto ao consumidor final de R\$ 2.000,00), e valor de operação de $\mathbf{R} \$ 1.000,00$. .102

Figura 3.2: Operação Normal do ICMS: débitos e créditos. 105

Figura 3.3: Operação com Substituição Tributária do ICMS: não há créditos aos adquirentes. 106

Figura 4.1 - Quadro das Funções da Contabilidade para o Direito Tributário (objeto da tese). .120

Figura 4.2 - Principais irregularidades econômico-contábeis que geram Presunção Legal de falta de pagamento de ICMS (artigo 509-A do RICMS/SP). 164

Figura 5.1 - Consideração Econômica - Prof. Luís Eduardo Schoueri. .211

Figura 5.2 - Mudança do padrão contábil brasileiro ao IFRS. 220 


\section{LISTA DE QUADROS E TABELAS.}

Quadro 3.1 - Quadro da Contabilização do ICMS Normal - RPA: Venda da Indústria ao Atacadista 105

Quadro 3.2 - Quadro da Contabilização do ICMS-ST ("para frente”): Venda da Indústria ao Atacadista. 106

Tabela 4.1 - Benefícios da NF-e (compilado pelo autor com base nos autores acima citados). 133

Tabela 4.2 - Benefícios do SPED (compilado pelo autor com base nos autores acima citados) 136

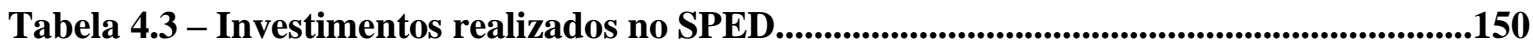

Quadro 5.1 - Tributos na Demonstração de Resultado do Exercício.........................................194

Quadro 5.2 - Arrecadação do ICMS x PIS-COFINS...............................................................203

Quadro 6.1 - Ajuste a Valor Presente - Exemplo..........................................................................280 


\section{CAPÍTULO 1 - INTRODUÇÃO.}

O título do projeto de tese de doutorado (As Funções da Contabilidade no ICMS Brasileiro: os impactos da convergência às normas contábeis internacionais e do projeto SPED - Sistema Público de Escrituração Digital) tem o objetivo ser um trabalho jurídico relevante, coadunando-se com a linha de pesquisa (direito econômico e desenvolvimento) e projeto acadêmico (legislação tributária e desenvolvimento econômico) multidisciplinares do orientador - Professor Associado Gerd Willi Rothmann na Faculdade de Direito da Universidade de São Paulo - USP. O tema atual é bastante relevante para o direito tributário, em uma área de pesquisa multidisciplinar que precisa continuar avançando no Brasil, seja no campo teórico como no campo prático. A conexão entre o direito tributário com a economia já vem se fortalecendo, mas também é necessário do mesmo modo se estudar a conexão do direito tributário com a contabilidade.

A pesquisa em direito tributário no Brasil por muitos anos se enveredou pela linha da teoria geral do direito e por uma abordagem, em geral, positivista e legalista, restringindo a pesquisa jurídica ao campo do próprio direito. No cenário atual, todavia, o direito tributário apresenta um desafio tanto para os advogados, consultores, especialistas na área de tributação, bem como para os auditores fiscais dos próprios Fiscos nas diversas esferas federativas (União, Estados e Municípios), na medida em que o mundo moderno é complexo e não admite na prática um reducionismo excessivo, uma vez que o direito tributário deve ser interpretado e aplicado dentro do contexto econômico e também deve considerar o contexto e os aspectos normativos da área contábil.

Seja do ponto de vista do processo administrativo contencioso (autuações e processo nos tribunais administrativos), seja do ponto de vista do processo administrativo consultivo (respostas ou soluções de consultas), as questões que se colocam hoje em dia extrapolam o próprio direito tributário e sua teoria interna, necessitando que os intérpretes do direito (contribuintes, advogados, auditores fiscais) avancem sobre a conexão e interrelação do direito tributário com outras ciências, seja dentro do próprio campo jurídico (conexões com o direito privado, econômico, financeiro, etc.), mas também exogenamente com outras ciências sociais aplicadas (conexões com a economia, contabilidade).

Em que pese, a enorme importância que os fundamentos principais da teoria geral do direito tributário possuem, e que também servem de embasamento para as bases teóricas deste trabalho, é preciso se enveredar por novas linhas de pesquisa, buscando pesquisas exógenas e multidisciplinares. Nesse contexto surgem diversas possibilidades de 
abordagem do direito tributário seja pela ótica das ciências contábeis (contabilidade), da economia e do direito econômico, dentre outras ciências.

A nossa escolha neste projeto de tese doutorado é abordar determinados aspectos essenciais da conexão e inter-relação entre estas duas ciências: contabilidade e direito tributário. Todavia, por uma questão metodológica é necessário que o pesquisador delimite seu campo de pesquisa, considerando que este campo de intersecção entre estas duas ciências (ciências contábeis e direito tributário) representa um "oceano" de possibilidades de pesquisas.

Desta forma, iremos delimitar como campo de nossa pesquisa o tema das funções da contabilidade para o ICMS brasileiro (objeto essencial do tema da tese) e os subtemas: dos efeitos tributários da nova contabilidade brasileira (padrão internacional) no ICMS e da importância da contabilidade (escrituração contábil) como obrigação acessória ao cumprimento da obrigação tributária especificamente no ICMS, analisada por meio do Projeto SPED (ou seja, duas acepções que expressam a utilidade essencial da contabilidade para o direito tributário).

\subsection{Delimitação do tema a ser desenvolvido e limitações da pesquisa.}

A palavra "contabilidade" não é unívoca e quando utilizada no sentido de função para o direito tributário, vislumbram-se quatro sentidos semânticos para a palavra “contabilidade": contabilidade como conceito e institutos contábeis utilizados na legislação triibutária; contabilidade como escrita comercial e respectivas demonstrações financeiras; contabilidade como técnica de auditoria contábil para fins tributários; contabilidade como prova no processo administrativo/judicial tributário.

Considerando os planos funcionais da contabilidade para o direito tributário podemos destacar as funções da contabilidade como elemento integrante da RMIT - Regra Matriz de Incidência Tributária (seja no fato gerador do tributo/hipótese de incidência do tributo, quando o conceito contábil for captado pelo direito tributário no antecedente da hipótese de incidência tributária; seja como elemento quantitativo da base de cálculo do tributo, nos casos em que o direito tributário elege um elemento quantitativo mensurado pela contabilidade no consequente da hipótese de incidência tributária); a contabilidade ou escrituração contábil (livros e registros contábeis) como obrigação acessória ao cumprimento da obrigação tributária (cujo exemplo mais notório é a obrigação de entrega do SPED-ECD que permite aos Fiscos ter acesso aos livros e registros contábeis das empresas por meio eletrônico); a contabilidade como técnica (auditoria contábil) para 
aferição de irregularidades econômico-fiscais; a contabilidade ou escrituração contábil como meio de prova para a constituição do lançamento tributário.

Figura 1.1 - Funções da Contabilidade para o Direito Tributário (objeto da tese).

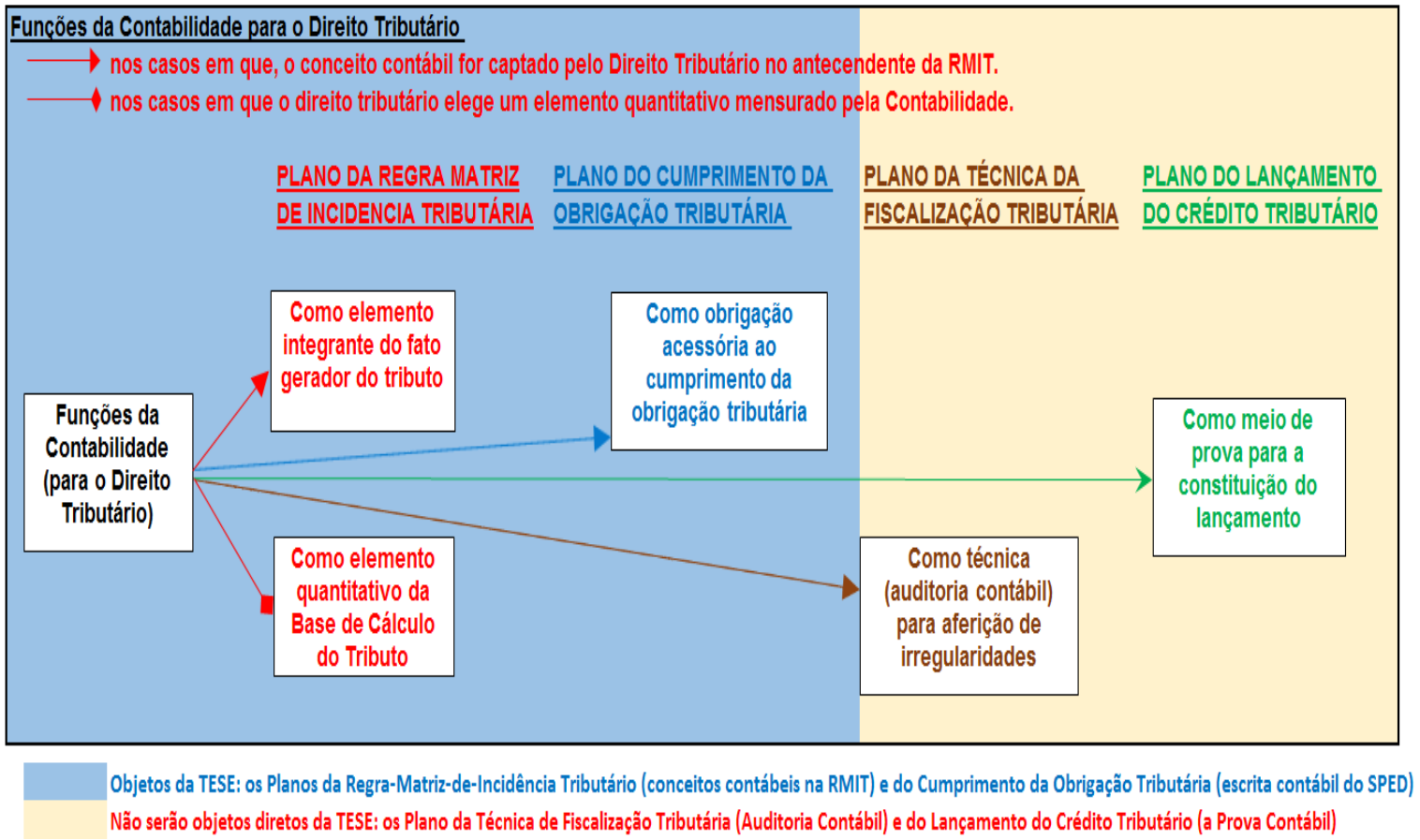

As funções da contabilidade para o ICMS constitui o objeto essencial do tema da tese, onde analisaremos a utilidade da contabilidade nos primeiros dois destes três planos do direito tributário sob o enfoque exclusivo do ICMS (no plano da regra matriz de incidência tributária como um elemento conceitual do fato gerador/hipótese de incidência do ICMS ou como um elemento do seu consequente/aspecto quantitativo, especialmente quanto à base de cálculo; no plano do cumprimento da obrigação tributária, no sentido de ser a contabilidade um elemento informacional ou um instrumento acessório para se assegurar o cumprimento da obrigação tributária principal do ICMS).

Desse modo, não aprofundaremos especificamente em temas que tratam diretamente da prova contábil em matéria tributária e da auditoria contábil na seara tributária, ou seja, de determinadas funções da contabilidade em matéria tributária: na contabilidade como técnica (auditoria contábil) para aferição de irregularidades econômico-fiscais; na contabilidade como meio de prova para a constituição do lançamento tributário (a prova contábil). Deste modo, também não será objeto diretamente desta tese o plano do lançamento do crédito tributário com um meio probatório da constituição do crédito tributário do ICMS. O motivo é que tais temas ainda que 
estivessem restritos ao ICMS demandariam uma tese específica, já que o tema da prova em matéria tributária é um tema específico e que demanda uma pesquisa peculiar, não se restringindo apenas à seara tributária, mas especialmente na seara do direito processual administrativo e judicial, o que só poderia ser tratado em um estudo específico sobre o tema da prova contábil na seara do processo administrativo/tributário.

Basicamente o tema a ser enfrentado na tese de doutorado (As Funções da Contabilidade no ICMS brasileiro: os impactos da convergência às normas contábeis internacionais e do projeto SPED - Sistema Público de Escrituração Digital) visa abordar dois blocos principais de interação:

a) A importância da contabilidade (escrituração contábil) como obrigação acessória ao cumprimento da obrigação tributária especificamente no ICMS, que será analisada por meio do Projeto SPED: o SPED (ECD/EFD) permite aos Fiscos ter acesso aos livros e registros contábeis das empresas por meio eletrônico. A tese irá analisar (no seu capítulo quatro) os principais aspectos da contabilidade como obrigação acessória ao cumprimento da obrigação tributária: a) os fiscos como usuários relevantes da informação contábil, com a abordagem da teoria contratual da firma (ou da denominada "teoria da contabilidade e do controle"); b) o projeto do SPED no contexto moderno das obrigações acessórias (ou deveres instrumentais informatizados), explicitando os principais pontos jurídicos e técnicos atinentes à escrituração contábil digital (ECD) e da escrituração fiscal digital (EFD, com ênfase principalmente no ICMS); c) o SPED, os custos de conformidade tributária (para administração tributária e contribuintes), e a administração de riscos fiscais pelas empresas contribuintes - temas contábeis essenciais a serem debatidos e com forte impacto no adequado cumprimento das obrigações tributárias principal e acessória; d) um tema jurídico essencial de direito tributário, que tende a ganhar repercussão e relevância nos próximos anos - o tema da informatização das informações contábeis e fiscais (SPED) e seus possíveis impactos no tradicional instituto jurídico do lançamento tributário.

b) Os efeitos tributários da nova contabilidade brasileira (padrão internacional) especificamente no ICMS (tema que expressa importante utilidade prática da contabilidade para o direito tributário): serão tratadas questões profundas e reflexivas, sobre os possíveis efeitos da nova contabilidade (padrão internacional) no ICMS e que impactam as entidades empresariais. Especialmente em relação aos tributos indiretos o tema é relativamente novo e inovador, já que a doutrina tem focado tão somente o PIS-COFINS federal e relegado os demais tributos sobre o consumo (como o 
ICMS e o IPI, por exemplo). Neste sentido, analisaremos os principais efeitos da mudança dos padrões contábeis nos ICMS, sendo importante detectar de que modo os conceitos contábeis na regra matriz de incidência (seja na hipótese de incidência/fato gerador quanto no seu consequente, especialmente quanto ao critério quantitativo) do ICMS foram afetados pelas alterações das normas contábeis.

Como limitações do estudo (ou limitações da pesquisa), embora o objetivo da tese seja traçar as principais funções da contabilidade no $\mathrm{ICMS}^{1}$, não será possível analisar todos os conceitos de contabilidade que estão presentes na legislação tributária estadual, nem analisaremos as relações que constituam precipuamente área de interesse exclusivo dos contabilistas. Dessa forma, não será objeto da presente tese as seguintes relaç̃es e inter-relacões entre o direito tributário (no que concerne ao ICMS) e a contabilidade:

a) a contabilidade como meio de prova do lançamento tributário (atinente ao tema jurídico da prova no direito no direito tributário): não aprofundaremos especificamente em temas que tratam diretamente da prova contábil em matéria tributária, ou seja, de determinadas funções da contabilidade em matéria tributária: na contabilidade como técnica (auditoria contábil) para aferição de irregularidades econômico-fiscais; na contabilidade ou escrituração contábil como meio de prova para a constituição do lançamento tributário. Como já ressaltado, tais temas ainda que estivessem restritos ao ICMS demandariam uma tese específica, já que o tema da prova em matéria tributária é um tema específico e que demanda uma pesquisa peculiar, não se restringindo apenas à seara tributária, mas especialmente na seara do direito processual administrativo e judicial. De outro modo o tema da técnica de auditoria contábil, ainda que possa ser utilizado para fins de fiscalização tributária, é um tema precipuamente da área de interesse exclusivo dos contabilistas e também demandaria um estudo ou tese específico, já que há obras que versam exclusivamente sobre o tema da auditoria contábil-tributária, inclusive para impostos indiretos. De qualquer forma, faremos algumas incursões inevitáveis e pontuais nestes temas, quando estritamente necessário para tratar de nossos temas principais que estão contemplados no título de nossa tese.

b) a exaustão de todos os conceitos de contabilidade que estejam presentes na legislação tributária estadual: como se sabe, a produção de legislação tributária no Brasil é especialmente esparsa e numerosa, e considerando a competência tributária dos diversos

\footnotetext{
${ }^{1}$ Notadamente como exposto enfocaremos em dois aspectos essenciais sobre os impactos no ICMS: da convergência às normas contábeis internacionais e do projeto SPED - Sistema Público de Escrituração Digital.
} 
Entes Federativos ainda que somente no âmbito do ICMS (há vinte e sete entes legislando), sendo que não raro, em muitas legislações atinentes à área tributária (não apenas em leis formais, mas em diversos atos normativos infralegais) são utilizados conceitos e definições que advém da área de ciências contábeis. Identificar todos e analisar todos os efeitos seria tarefa pouco proveitosa e extremamente casuística, de modo que o importante para a tese é focar nos temas objeto do título da tese que envolvem as funções da contabilidade para o ICMS, e principalmente como se dá a utilidade da contabilidade (escrituração contábil com o advento do SPED) no direito tributário, em específico do ICMS. Serão estudados também os principais efeitos tributários das novas normas contábeis brasileiras quanto aos elementos essenciais da regra matriz de incidência do ICMS (no capítulo 6, que é o principal capítulo da tese).

c) As funções do direito tributário para a contabilidade (objeto de pesquisa dos contabilistas): não será objeto direto de nosso estudo a utilidade do direito tributário para a contabilidade, embora possamos em alguns momentos fazer menção a alguns aspectos desta utilidade. Nesta seara estará expressamente fora do nosso objeto de escopo as funções e os efeitos do direito tributário na contabilidade financeira (para a mensuração e evidenciação adequada dos ativos, passivos, receitas e despesas nas demonstrações contábeis relacionados aos tributos) e na contabilidade gerencial (para a tomada de decisão e no planejamento financeiro e tributário das empresas).

Figura 1.2 - Funções do Direito Tributário para a Contabilidade (que não integra o objeto da tese limitações do estudo).

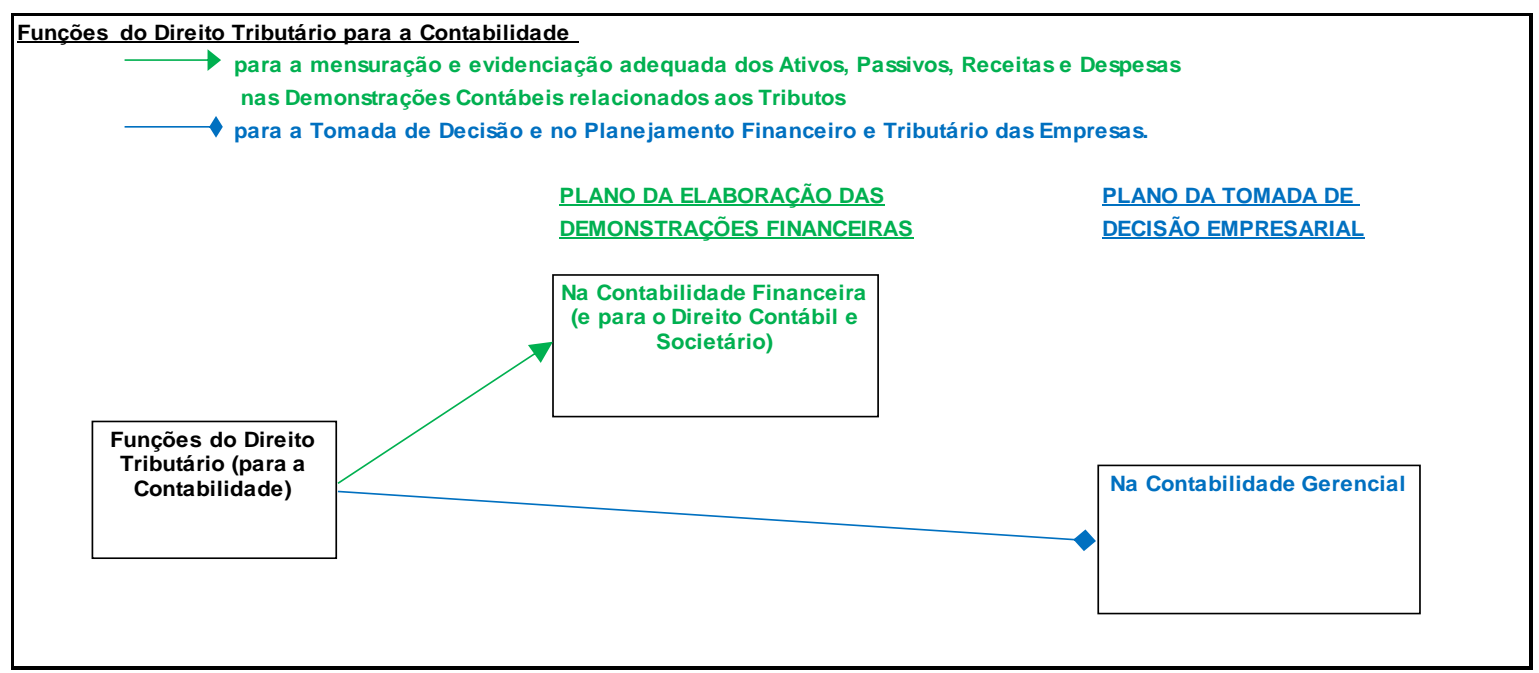

c) funções do direito tributário e da contabilidade para o desenvolvimento econômico: não será objeto direto de nosso estudo a utilidade do direito tributário e da 
contabilidade como instrumentos para o desenvolvimento econômico, uma vez que a interação entre as normas tributárias e as normas contábeis, em conjunto possuem um efeito indutor sobre o comportamento das empresas e um papel na economia. Também embora tenha que se reconhecer a contribuição dos estudos quantitativos na área de Ciências Contábeis para a política fiscal tributária dos governos, e consequentemente, a possibilidade de sua utilização nas decisões de alteração da legislação tributária, também não será objeto de nossa tese a utilização da Contabilidade como instrumento de mensuração do comportamento das empresas e dos contribuintes em face da tributação:

Figura 1.3 - Funções do Direito Tributário e da Contabilidade para o Desenvolvimento Econômico (que não integra o objeto da tese - limitações do estudo).

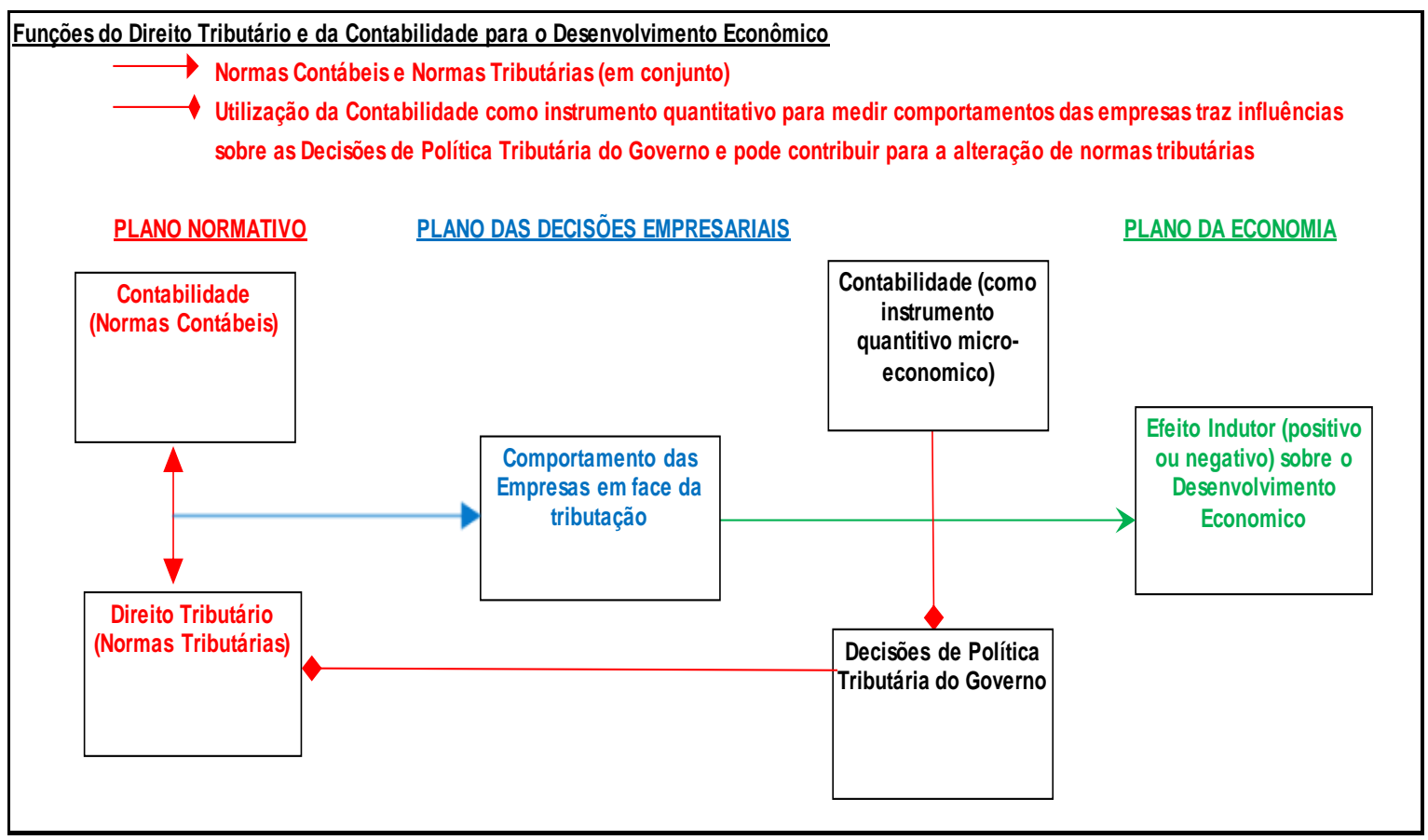

\subsection{Justificativa da escolha, da importância e originalidade do tema.}

O tema a ser enfrentado na tese de doutorado (As Funções da Contabilidade no ICMS brasileiro: os impactos da convergência às normas contábeis internacionais e do projeto SPED - Sistema Público de Escrituração Digital) se justifica na medida em que o direito tributário se utiliza das ciências contábeis pelos mais diversos prismas, sendo estes os dois planos de análise mais fundamentais: o da utilização de conceitos contábeis pelo legislador tributário e da utilização da contabilidade (escrita comercial) como obrigação acessória tributária

Há situações em que o próprio direito tributário (no caso especificamente se analisando o ICMS) se refere a conteúdos, conceitos e institutos contábeis, chamando a 
atenção, especialmente, as situações em que os conceitos contábeis interferem em algum elemento essencial do antecedente da norma matriz de incidência tributária (vulgarmente chamada também de "fato gerador") de determinados tributo; ou interfere no elemento quantitativo da base de cálculo do tributo. Por isto há necessidade em se verificar nestes casos pontuais, em que há conceitos contábeis capturados na RMIT do tributo (no caso do ICMS), se o novo padrão contábil internacional (IFRS) pode causar impactos tributários para aquele tributo analisado.

$\mathrm{Na}$ segunda acepção funcional menciona-se o uso da contabilidade (no sentido de registros e livros contábeis) como obrigação acessória dos próprios fiscos (com ênfase no fisco estadual). Isto porque, os fiscos das diversas esferas federativas são usuários relevantes da informação contábil. Frise-se neste sentido, como exemplo relevante, o Sistema Público de Escrituração Digital (SPED) que prevê que os livros e documentos que integram a escrituração comercial e fiscal dos empresários e das sociedades empresárias serão emitidos em forma eletrônica, com especial atenção ao subprojeto ECD Escrituração Contábil Digital, pois este último trata da escrita comercial propriamente dita.

Adicionalmente, o tema a ser enfrentado na tese de doutorado se justifica na medida em que as recentes alterações normativas da legislação societária e das próprias normas contábeis (em virtude da convergência da contabilidade brasileira aos padrões internacionais) também pode trazer impactos significativos ao direito tributário e para as entidades empresariais em relação aos diversos tributos diretos e indiretos, e no caso especificamente analisado e estudado também no ICMS (como será demonstrado no capítulo 6).

Neste sentido a originalidade (contribuição original à ciência jurídica brasileira) deste projeto de tese é o de propor um estudo verdadeiramente multidisciplinar, de como se relaciona o direito tributário e a contabilidade em relação a um tributo indireto específico (o ICMS). Neste sentido pretendemos estudar a conexão (a ligação; o enlace ou vínculo entre as ciências; a relação ou ligação lógica entre elas), bem como e a inter-relação (relação mútua que se estabelece) entre estas duas ciências. Em parte, a originalidade também se justifica pela tentativa de consolidação de diversas temáticas ainda dispersas, embora estejam já sendo discutidas doutrinariamente e na prática jurídica.

A originalidade também consiste em estabelecer uma linha de pesquisa sobre a conexão e a inter-relação da contabilidade e do direito tributário no ICMS, já que a maior parte dos trabalhos nesta seara consiste em temas bem específicos e tecnocráticos apenas no âmbito do Imposto de Renda e das Contribuições do PIS e COFINS. A maior parte dos 
trabalhos e livros relevantes sobre o ICMS, em que pese a qualidade dos renomados autores, raramente ousa cogitar qualquer interferência das normas contábeis na regra matriz do ICMS. Ao estudarmos os impactos da convergência das normas contábeis internacionais no ICMS (objeto de nosso penúltimo capítulo antes das conclusões) certamente estaremos adentrando num tema inovador, técnico, e pouco explorado seja pelos Fiscos estaduais como pelos próprios contribuintes.

O nosso enfoque neste trabalho, conforme já destacado na limitação de estudo, é pesquisar as funções da contabilidade para o ICMS enfocando dois temas principais. Isso se justifica na medida em que se trata de uma tese de doutorado na área de direito tributário, e por isto, é a delimitação de pesquisa que mais interessa e é mais útil ao jurista e ao tributarista. Isto não significa reduzir a contabilidade a um mero instrumento que possa ser utilizado pelo direito tributário (no caso pelo ICMS). Em verdade trata-se de uma ciência social aplicada de extrema relevância, todavia, para fins de pesquisa o objeto de estudo que interessa na tese é justamente explicar as duas principais funções da contabilidade para o direito tributário: no plano da regra matriz do ICMS (hipótese de incidência tributária e consequente quantitativo do ICMS) e no plano do cumprimento da obrigação tributária do ICMS por meio do projeto SPED, conforme já apontado na figura 1.1 no subitem anterior.

Todavia, quanto ao caminho contrário, de como o direito tributário interfere na contabilidade (seja na contabilidade financeira e na gerencial), conforme apontamos anteriormente no subitem anterior, preferimos fazer uma limitação de escopo ao estudo neste sentido. Deste modo, não serão estudados os temas relativos à contabilidade financeira para a mensuração e evidenciação adequada dos ativos, passivos, receitas e despesas nas demonstrações contábeis relacionados aos tributos ou ao ICMS. Também sabemos que as entidades empresariais precisam planejar suas atividades, projetar fluxos de caixa, receitas, despesas, rentabilidade, e necessariamente deverão conhecer o impacto dos tributos (e do ICMS) sobre suas atividades. Mas também não será objeto desta tese a ótica da contabilidade gerencial de como o conhecimento do direito tributário contribui para o planejamento financeiro e tributário das empresas.

Da mesma forma, embora saibamos que a interação entre as normas tributárias e as normas contábeis, em conjunto, possuem um efeito indutor sobre o comportamento das empresas e um papel na economia, não será objeto direto de nosso estudo a utilidade do direito tributário e da contabilidade como instrumentos para o desenvolvimento econômico, uma vez que por conta da complexidade do tema este estudo iria requerer a 
elaboração de uma tese específica que delimitasse somente este assunto. Dessa forma, conforme delimitamos no subitem anterior não será objeto da presente tese as funções do direito tributário e da contabilidade para o desenvolvimento econômico.

\subsection{Principais questões a serem analisadas sobre o tema.}

A pesquisa apresenta como principais questões:

A) A nova contabilidade brasileira e as alterações nas leis societárias para convergências às normas contábeis em padrão internacional (IFRS). Juridicidade das normas jurídico-contábeis emanadas pelo CPC. Características do novo padrão contábil (IFRS) e a prevalência da essência econômica sobre a forma jurídica. Relação do direito tributário com as normas contábeis:

$\mathrm{Na}$ primeira parte da tese (capítulo dois) analisaremos quais foram as principais mudanças na contabilidade brasileira e do ponto de vista societário, trazidas pelas Leis $\mathrm{n}^{\circ} \mathrm{S}$ 11.638/2007 e 11.941/2.009, no intuito de harmonizar os padrões contábeis brasileiros às normas de contabilidade no padrão internacional (IFRS). Um ponto jurídico essencial e que depois utilizaremos como uma das bases e premissas de nossa tese, é demonstrarmos a juridicidade das normas jurídico-contábeis emanadas pelo Comitê de Pronunciamento Contábeis - CPC no Brasil. É preciso também que o jurista conheça as principais características do novo padrão contábil (IFRS) para entender a lógica contábil e dentre estas características caberá destacar o princípio contábil da essência econômica sobre a forma jurídica, que deve ser analisado com mais cuidado. Nesta primeira parte, ainda que se tratem de construções teóricas insculpidas principalmente no âmbito do Imposto de Renda, será adequado tratarmos da relação do direito tributário com as normas contábeis sob as classificações de conexão e dependência entre o balanço contábil e o "balanço fiscal”, pois depois tais conclusões serão extravasadas no capítulo cinco e sei para nosso tema específico (impactos tributários das novas normas contábeis internacionais no ICMS).

\section{B) ICMS: aspectos jurídicos e contábeis}

Nosso objetivo neste ponto (capítulo três) será demonstrar os aspectos essenciais do ICMS, como um imposto sobre o valor agregado, suas características essenciais no modelo jurídico brasileiro insculpido pela Lei Complementar 87/1996, demonstrando as características da hipótese de incidência da RMIT do ICMS (operações relativas à circulação de mercadorias) do ponto de vista do conceito econômico juridicizado no 
aspecto material do imposto. Enfatizaremos o princípio da autonomia dos estabelecimentos para demonstrarmos as peculiaridades da relação do ICMS com a contabilidade (escrita contábil), tratando dos aspectos essenciais da contabilização do ICMS (regime próprio e substituição tributária) e enfatizando os aspectos jurídicos e contábeis que diferenciam o ICMS de outros tributos sobre o consumo (como as contribuições federais PIS-COFINS).

C) O projeto SPED: a contabilidade ou escrituração contábil (livros e registros contábeis) como obrigação acessória ao cumprimento da obrigação tributária no ICMS. Os Fiscos como usuários relevantes da informação contábil:

Aqui será analisada a importância da contabilidade (no sentido de escrituração contábil - livros e registros contábeis) como obrigação acessória relevantíssima para a fiscalização tributária, uma vez que a mesma é fonte de informação essencial nas auditorias tributárias de todos os fiscos (federal, estaduais, municipais), sendo que nosso enfoque é a relevância da informação contábil para os Fiscos estaduais em relação ao ICMS.

Em decorrência da evolução tecnológica e o aumento dos volumes das operações realizadas pelas empresas, as fiscalizações tributárias da União, dos Estados, Distrito Federal e Municípios se viram diante de desafios operacionais que as obrigavam a se modernizar para acompanhar o desenvolvimento das empresas e das tecnologias.

Contudo, para tal modernização era necessária uma mínima uniformização das obrigações acessórias, solicitadas pelas várias esferas de governo. A fim de dar início a uma mínima padronização, foi editada a Emenda Constitucional no 42 de 19 de Dezembro de 2003, introduzindo o inciso XXII ao artigo 37 da Constituição Federal de 1988, determinando que as administrações tributárias da União, Estados, Distrito Federal e Municípios atuem de forma integrada, compartilhando cadastros e informações fiscais.

A medida implementada teve como objetivo a modernização e a racionalização das informações, promovendo a ação integrada entre as esferas de fiscalização, possibilitando a centralização da informação em um banco de dados único.

O Decreto Federal n ${ }^{\circ}$ 6.022, de 22 de janeiro de 2007, alterado pelo Decreto Federal n 7.979 , de 08 de abril de 2013, instituiu o Sistema Público de Escrituração Digital Sped.

"Art. $2^{\circ}$ O Sped é instrumento que unifica as atividades de recepcão, validacão, armazenamento e autenticacão de livros e documentos que integram a escrituração contábil e fiscal dos empresários e das pessoas jurídicas, inclusive imunes ou isentas, mediante fluxo único, computadorizado, de informações”. 
O SPED tem como principais objetivos: a) promover a integração dos fiscos mediante a padronização e compartilhamento das informações contábeis e fiscais, respeitadas as restrições legais; b) racionalizar e uniformizar as obrigações acessórias para os contribuintes, com o estabelecimento de transmissão única de distintas obrigações acessórias de diferentes órgãos fiscalizadores; c) tornar mais célere a identificação de ilícitos tributários, com a melhoria do controle dos processos, a rapidez no acesso às informações e a fiscalização mais efetiva das operações com o cruzamento de dados e auditoria eletrônica. Para isto o SPED prevê que os livros e documentos que integram a escrituração comercial e fiscal dos empresários e das sociedades empresárias serão emitidos em forma eletrônica.

Irá se demonstrar neste ponto que os fiscos das diversas esferas federativas são usuários relevantes da informação contábil, de modo a se enfatizar um aspecto funcional primordial da contabilidade para o direito tributário no plano do cumprimento das obrigações tributárias. Por isto será dado destaque neste capítulo 4 específico ao SPED: SPED Contábil (ECD - Escrituração Contábil Digital) e o SPED Fiscal (EFD Escrituração Fiscal Digital), discutindo questões jurídicas e contábeis essências trazidas pelo advento do SPED, conforme já enfatizamos no subitem 1.1 na delimitação do tema.

A tese irá analisar (no seu capítulo quatro) os principais aspectos da contabilidade como obrigação acessória ao cumprimento da obrigação tributária: a) os fiscos como usuários relevantes da informação contábil, com a abordagem da teoria contratual da firma (ou da denominada "teoria da contabilidade e do controle"); b) o projeto do SPED no contexto moderno das obrigações acessórias (ou deveres instrumentais informatizados), explicitando os principais pontos jurídicos e técnicos atinentes à escrituração contábil digital (ECD) e da escrituração fiscal digital (EFD, com ênfase principalmente no ICMS); c) o SPED, os custos de conformidade tributária (para administração tributária e contribuintes), e a administração de riscos fiscais pelas empresas contribuintes - temas contábeis essenciais a serem debatidos e com forte impacto no adequado cumprimento das obrigações tributárias principal e acessória; d) um tema jurídico essencial de direito tributário, que tende a ganhar repercussão e relevância nos próximos anos - o tema da informatização das informações contábeis e fiscais (SPED) e seus possíveis impactos no tradicional instituto jurídico do lançamento tributário; e) o advento de normas contábeis de “disclosure" relativas a subvenções e assistências governamentais, que podem servir como instrumento ao fisco de combate à "guerra fiscal" no ICMS e também aumentar o risco de detecção das empresas neste tipo de autuação. 
f) o reconhecimento contábil da receita de vendas de mercadorias em situações de dessincronização com o fato gerador do ICMS (exemplo dos ativos biológicos), ocasionando maiores dificuldades e riscos nos processos de auditoria contábil com fins tributários.

\section{D) Consideração Econômica e a positivação na legislação tributária de conceitos} econômico-contábeis:

Nosso objetivo neste ponto será demonstrar a utilidade da consideração econômica (ou interpretação econômica) no contexto do direito tributário, especialmente nas situações em que há uma positivação na legislação tributária de conceitos econômico-contábeis. Nosso objetivo será o de reconhecer a possibilidade do legislador tributário conscientemente utilizar critérios econômicos e contábeis na definição da materialidade e hipótese de incidência dos tributos. Nesse sentido, estes conceitos deixam de ser estritamente econômicos ou contábeis para também serem jurídicos, na medida em que se reconheça sua positivação. Estes temas (consideração econômica, a importância das classificações econômico-contábeis juridicizadas para o direito tributário, e a possiblidade de positivação na legislação tributária de conceitos econômicos-contábeis) serão tratados na primeira parte do capítulo cinco (subitens 5.1 a 5.4).

\section{E) Juridicidade das normas contábeis no direito privado e positivação de conceitos contábeis na Regra-Matriz de Incidência dos Tributos:}

No capítulo cinco além de discutirmos essencialmente a positivação na legislação tributária dos conceitos econômico-contábeis, enfocaremos especificamente a juridicidade das regras contábeis (verdadeiras normas jurídicas de direito privado comercial/societário), e destacando notadamente a relação das normas contábeis (de direito privado) com as normas tributárias, , demonstrando a possibilidade do legislador tributário adotar conceitos contábeis como normatizado no direito privado ou modificá-los para fins tributários.

Será demonstrado, que o legislador tributário pode adotar conceitos contábeis na regra-matriz de incidência dos tributos (no antecedente e no consequente), não apenas no IRPJ, mas em outros tributos, inclusive, no ICMS (ainda que em situações pontuais). Neste caso, sob o enfoque dos artigos 109 e 110 do CTN, o legislador pode decidir modificar ou não o conceito utilizado de direito privado das normas contábeis apenas para fins dos seus efeitos tributários por conta da autonomia do direito tributário. Todavia, naquilo que o 
conceito de direito contábil não é alterado, a legislação tributária deve seguir as normas de direito contábil (direito privado) quanto à definição, reconhecimento, mensuração conforme aqueles institutos contábeis no seu campo origem, e este será o ponto de partida da interpretação e aplicação da legislação tributária.

F) Conceitos contábeis na regra-matriz de incidência dos tributos: quando o conceito contábil for captado pelo direito tributário (como elemento integrante do fato gerador/hipótese de incidência do tributo; como elemento quantitativo da base de cálculo do tributo, quando a legislação tributária elege um elemento quantitativo mensurado pela contabilidade). Exemplos de conceitos contábeis na Regra Matriz de Incidência do ICMS.

Analisaremos na parte final do capítulo cinco, umas das principais funções da contabilidade para o direito tributário, na positivação de conceitos contábeis na regramatriz de incidência dos tributos: quando o conceito contábil for captado pelo direito tributário (como elemento integrante do fato gerador/hipótese de incidência do tributo; como elemento quantitativo da base de cálculo do tributo, quando a legislação tributária elege um elemento quantitativo mensurado pela contabilidade).

Veremos que a adoção de conceitos contábeis na regra-matriz de incidência dos tributos (no antecedente e no consequente), ocorre não apenas no IRPJ, mas em outros tributos, inclusive, no ICMS (ainda que em situações pontuais).

Serão apresentados exemplos de conceitos contábeis na Regra Matriz de Incidência do ICMS no final do capítulo cinco. O ICMS apenas pontualmente faz referência a conceitos contábeis, mas quando o faz podem sim haver impactos tributários advindos do novo padrão contábil (IFRS), e a análise pragmática deste tema no ICMS será detalhada no capítulo seis.

\section{G) Os efeitos tributários da nova contabilidade brasileira (padrão internacional)} no ICMS:

Aqui serão tratadas questões práticas e pragmáticas que interessam aos Fiscos estaduais, às empresas, aos advogados tributaristas e aos contabilistas, sobre os possíveis efeitos da nova contabilidade (padrão internacional) no ICMS (tributo indireto).

Especialmente em relação aos tributos indiretos o tema é relativamente novo e inovador, e especificamente em relação ao ICMS, não há praticamente trabalhos doutrinários e até mesmo práticos sobre temas de preocupação dos Fiscos Estaduais e dos 
contribuintes. As discussões da nova contabilidade em tributação indireta têm se atido normalmente aos tributos sobre a renda e às contribuições federais do PIS-COFINS.

No âmbito da Secretaria da Fazenda de São Paulo houve um estudo dos impactos dos novos critérios de reconhecimento, mensuração e evidenciação dos elementos contábeis e das operações das empresas trazidos pela convergência às Normas Internacionais de Contabilidade e pelas Leis 11.638/2007 e 11.941/2.009 no âmbito do Projeto PROFISCO 4.8. ${ }^{2}$ Uma questão importante, a ser analisada conceitualmente e na prática, é se o ICMS estaria ou não garantido pelo chamado Princípio da "Neutralidade Tributária" ou se sua tributação sofreria algum efeito com os novos critérios contábeis, uma vez que a Lei Federal 11.941/2.009 disciplina apenas os tributos federais (principalmente Imposto de Renda - Lucro Real, e também estende estes efeitos à CSLL, PIS e COFINS).

Para exemplificar uma problemática no ICMS que será discutida no capítulo seis, podemos citar a introdução do novo mecanismo contábil do “ajuste a valor presente", que no caso de empresas comerciais que praticam com relevância vendas a prazo (financiada pela própria empresa), implica no reconhecimento das receitas de mercadorias a valor presente, e na segregação contábil dos “juros” em virtude do financiamento (ainda que pela própria entidade empresarial). Tal procedimento contábil traz de certa forma um "risco fiscal" aos Estados no que se refere à mensuração das receitas tributáveis pelo ICMS. Embora esteja literalmente escrito na Lei Kandir (alínea "a" do inciso II do $\S 1^{\circ}$ do artigo 13 da Lei Complementar 87/1996) que os juros estejam incluídos na base de cálculo do ICMS, a publicação de Balanços e Demonstrações Contábeis com a informação da incidência do ICMS sobre os juros, podem acirrar uma disputa entre os fiscos estaduais e as grandes empresas comerciais que têm esta prática comercial, ensejando questionamentos jurídicos e à prática de planejamento tributários que podem ser objeto de lide.

\subsection{Metodologia utilizada na pesquisa.}

\footnotetext{
${ }^{2}$ O Grupo de Trabalho PROFISCO 4.8 foi voltado à implantação do Sistema Público de Escrituração Digital (SPED) na Secretaria da Fazenda-SP atuou nas seguintes vertentes:

1.Escrituração Contábil Digital (ECD) e Escrituração Fiscal Digital EFD (para os contribuintes de ICMS e IPI);

2.Definição dos Novos Roteiros de Auditoria Fiscal e Contábil na Fiscalização do ICMS pela SEFAZ-SP;

3. Análise dos Impactos na Auditoria Fiscal dos novos critérios de reconhecimento, mensuração e evidenciação dos elementos contábeis e das operações das empresas trazidos pelas Normas Internacionais de Contabilidade.

4-Treinamento em Auditoria Contábil Tributária Digital de 1.800 Fiscais da SEFAZ-SP.
} 
Uma pesquisa científica requer uma metodologia a ser observada na condução do trabalho, ou seja, um conjunto de instrumentos e procedimentos técnico-científicos a serem usados e seguidos no desenvolvimento da pesquisa.

A pesquisa científica ${ }^{3}$ é um processo de busca de conhecimento a partir de instrumentos e procedimentos que possam ser controláveis, e ao mesmo tempo sejam passíveis de repetição por outro pesquisador. Desta forma só são científicas (legítimas) as respostas e conclusões de questões de pesquisa, que sigam um instrumental e método de pesquisa predefinido pelo pesquisador.

Por isto que uma pesquisa científica deve se pautar pelas características da investigação científica ${ }^{4}$, ou seja, deve ser sistemática (investigação pautada por uma disciplina e planejamento), empírica (pesquisa que busca ordenadamente novas informações, analisando-as com seriedade) e crítica (investigação que se auto aperfeiçoa e que reflete sobre o próprio procedimento planejado de estudo).

O importante é que a pesquisa científica seja conduzida observando-se as características essenciais à cientificidade ${ }^{5}$ : a coerência lógica (as conclusões devem ser consequências das premissas e raciocínios desenvolvidos no decorrer do trabalho), a consistência (as ideias e argumentos são sólidos, pois não ignoram as teorias existentes e as discussões atuais, e justificadamente resistem a contra-argumentos), a originalidade (a pesquisa não reflete mera repetição ou compilação de ideias, e apresenta algo novo, ou pelo menos apresenta uma visão crítica diferenciada sobre temas já amplamente estudados), a objetivação (o esforço do pesquisador em evitar o uso de ideologias ou pressuposições anteriores à pesquisa), a intersubjetividade (se a pesquisa analisou criticamente o diálogo, os argumentos e a opinião dos principais pesquisadores da área).

Tratando especificamente das teses jurídicas (e obras jurídicas, em geral), o Professor Eduardo Cesar Silveira Vita Marchi ${ }^{6}$ ressalta que para ser científica deve apresentar basicamente dois requisitos. O primeiro requisito é a originalidade ${ }^{7}$ (o autor deve descobrir algo novo ou reconfirmar o que já é conhecido por uma ótica diversa - por

\footnotetext{
${ }^{3}$ LAMY, Marcelo. Metodologia da Pesquisa Jurídica (Técnicas de Investigação, Argumentação e Redação). Rio de Janeiro, Editora Elsevier, 2011, p. 44-48.

${ }^{4}$ LAMY, Marcelo. Op. cit., p. 19.

${ }^{5}$ LAMY, Marcelo. Op. cit., p. 61-63.

${ }^{6}$ MARCHI, Eduardo C. Silveira. Guia de Metodologia Jurídica (Teses, Monografias e Artigos). $2^{\mathrm{a}}$ Ed., São Paulo, Editora Saraiva, 2009, p. 20-29.

7 Como nos adverte o Professor Eduardo Cesar Silveira Vita Marchi: “A originalidade, entendida como novidade, pode estar espalhada ao longo do trabalho, por meio de (mesmo pequenas) observações, críticas ou interpretações inéditas sobre certos pontos tratados". (MARCHI, Eduardo C. Silveira. Guia de Metodologia Jurídica (Teses, Monografias e Artigos). 2a Ed., São Paulo, Editora Saraiva, 2009, p. 21).
} 
exemplo, uma nova interpretação para um dispositivo legal ou para um problema jurídico, ou ainda, a apresentação de novos argumentos em favor de uma tese já conhecida -, sendo que a originalidade normalmente é demonstrada no momento de reelaboração do material pesquisado, ou seja, o autor deve repropor com suas próprias palavras o conteúdo e as ideias dos textos pesquisados, acrescendo de críticas e observações pessoais, de preferências novas e inéditas). O segundo requisito á a veracidade (que consiste na prova de que as afirmações correspondem à verdade científica e possam ser comprovadas, ou seja, uma tese deve fornecer elementos que possibilitem a verificação das opiniões e pareceres apresentados - assim uma obra jurídica deve ser acompanhada necessariamente das provas materiais - deve citar exatamente a fonte que pode ser a legislação, a jurisprudência ou a doutrina - e das provas substanciais - deve interpretar estes elementos de modo lógico e coerente, emitindo seu parecer e interpretação).

Quanto aos métodos, como ressalta o Professor Cesar Silveira Vita Marchi ${ }^{8}$, no âmbito das ciências jurídicas a pesquisa pode usar de variados métodos, como por exemplo, os métodos: dialético, coleta de jurisprudência, comparístico, histórico, indutivo ou dedutivo e até mesmo estatístico, dentre outros. Não existem métodos de abordagem e de procedimento melhores ou superiores, mas sim métodos mais úteis ou menos úteis aos objetivos da pesquisa.

Neste ponto, é interessante anotarmos que a complexidade de alguns temas do conhecimento científico abre caminho para a necessidade da adoção da interdisciplinaridade ${ }^{9}$ nas pesquisas, uma vez que a realidade tão emaranhada não pode ser, muitas vezes, captada pelo olhar de uma disciplina isolada. Como nos ensina Pedro Demo " a interdisciplinaridade dá o recado inverso do modernismo formalista: não é a realidade que tem que caber nos métodos, são estes que precisam captar a realidade, moldando-se a ela" 10 .

Especialmente no campo de estudo da tributação ${ }^{11}$ verifica-se hoje cada vez mais a necessidade da utilização de conhecimentos interdisciplinares (Direito, em suas várias facetas - tributário, constitucional, administrativo, civil, comercial, processual; bem como

\footnotetext{
${ }^{8}$ MARCHI, Eduardo C. Silveira. Op. cit., p. 86-87.

${ }^{9}$ DEMO, Pedro. Metodologia do conhecimento científico. São Paulo: Atlas, 2000, p. 70-73.

${ }^{10}$ DEMO, Pedro. Op. cit., p. 72.

11 "Aos poucos, porém, surgem áreas mais convergentes, cujo tratamento disciplinarizado, já parece absurdo, como qualidade de vida, desenvolvimento humano, ecologia, planejamento estratégico, urbanização etc. Os cursos de pós-graduação possivelmente serão cada vez mais interdisciplinares, porque se entende que profissional polivante pode ser mais completo, desde que não seja gestado pelo acúmulo de conhecimentos ainda mais incompletos". (DEMO, Pedro. Metodologia do conhecimento científico. São Paulo: Atlas, 2000, p. 73).
} 
conhecimentos de outras áreas do conhecimento, como, por exemplo, das Ciências Contábeis e a Economia). No tema objeto de nosso estudo para que a pesquisa atinja bons resultados devemos também estudar com certa profundidade a tributação sob o prisma das Ciências Contábeis, uma vez que nosso objetivo é o de estudar a conexão (a ligação; o enlace ou vínculo entre as ciências; a relação ou ligação lógica entre elas), bem como e a inter-relação (relação mútua que se estabelece) entre o Direito Tributário e a Contabilidade, já que estamos abordando duas funcionalidades essenciais da contabilidade para o direito tributário (com o enfoque no imposto estadual - ICMS).

Evidentemente que a interdisciplinaridade não significa que o pesquisador deva navegar indiscriminadamente por qualquer outra ciência sem o devido conhecimento, e sem uma delimitação segura do seu objeto de pesquisa. Tratando-se de um Projeto de Tese de Doutorado no curso de Pós-Graduação em Direito da USP do Departamento de Direito Econômico-Financeiro-Tributário, é primordialmente necessária primeiramente uma profunda análise jurídica, e a interdisciplinaridade pressupõe também que o pesquisador faça um grande esforço para estudar adequadamente a outra disciplina que deseja contrapor (no caso, a Contabilidade).

Por isto nossa metodologia contempla a interdisciplinaridade ${ }^{12}$ na medida em que a pesquisa interdisciplinar é necessária: seja porque quando reduzimos a realidade àquilo que somente o método jurídico capta distorcemos a realidade; bem como porque a realidade como tal, sendo complexa, apresenta-se multifacetada. Especialmente, quanto à pesquisa bibliográfica, utilizaremos de pesquisa de livros, artigos e teses da área jurídico-tributária e também da área de contabilidade.

Neste presente trabalho serão utilizados os seguintes métodos:

A) Método Dialético, ou seja, sempre que possível, a análise e discussão doutrinária de posições antagônicas em relação aos problemas e argumentos relativos à interação entre o Direito Tributário e a Contabilidade. Pois uma pesquisa científica certamente não pode somente se enveredar prematuramente por posições doutrinárias prédefinidas, especialmente se a pesquisa bibliográfica em alguns tópicos demonstrar a existência de posições doutrinárias opostas. Na verdade, a diversidade de opiniões é o que enriquece um trabalho verdadeiramente científico e acadêmico. Todavia, é claro, o autor tem a obrigação de se posicionar academicamente sobre os pontos polêmicos que se

${ }^{12}$ DEMO, Pedro. Op. cit., p. 71-72. 
colocam, mas deve sempre justificar suas posições de modo científico, demonstrando o porquê da assertividade de certa posição, e o porquê de sua objeção em relação à outra;

B) Método de Coleta de Jurisprudência, ou seja, a necessária coleta de decisões judiciais relativas ao tema, pesquisando julgados representativos que envolvem os temas das funções da contabilidade para o direito tributário nos Tribunais de Justiça dos Estados, e especialmente, no Superior Tribunal de Justiça e Supremo Tribunal Federal, e principalmente em esferas administrativas (tribunais administrativos, e, respostas ou soluções de consulta dos Fiscos Estaduais). Evidentemente que uma pesquisa com um tema de extrema relevância prática exige a verificação de algumas tendências dos tribunais (administrativos/judiciais) no que concerne aos principais problemas do tema tratado, e por isto exigem uma análise e discussão jurisprudencial. Sendo um trabalho acadêmico e científico não há a simples exposição das posições dos julgados, mas sim, uma exposição destes posicionamentos, acompanhadas de críticas e comentários do autor devidamente embasados pela doutrina;

C) Método Indutivo e Dedutivo, ou seja, através do método indutivo se faz a análise e observação de casos concretos que envolvem as funções da contabilidade para o direito tributário, que é basicamente o que será feito na parte pragmática do trabalho no capítulo 6, onde serão analisados os impactos tributários do novo padrão contábil (IFRS) no ICMS. De outro modo, através do método dedutivo, se parte da análise de princípios e da estrutura jurídica do ICMS, bem como da teoria do direito tributário, bem como dos princípios e características do novo padrão contábil e da teoria contábil, para verificarmos a aplicação prática em seus diversos aspectos aos casos concretos;

D) Pesquisa Bibliográfica ${ }^{13}$, ou seja, é um método (para alguns autores, um tipo de pesquisa) que pode ser combinado com os já expostos, que consiste em explicar os problemas com base em teorias já publicadas em livros e artigos por outros autores. Consiste no método em que o investigador levanta o conhecimento disponível na área, identifica as teorias produzidas, analisa-as e avalia suas contribuições teóricas para determinados problemas. Sua utilidade é importante para algumas finalidades, e especificamente em nosso trabalho, para ampliar o conhecimento e capacitar-nos como investigador a compreender e delimitar os problemas de pesquisa do tema, e também serve para dominarmos o conhecimento disponível, tendo em vista a fundamentação e construção de nossos modelos teóricos explicativos dos problemas relacionados ao tema

${ }^{13}$ KOCHË, José C. Fundamentos de metodologia científica; teoria da ciência e prática da pesquisa. Petrópolis: Vozes, 1997, p. 122. 
(As Funções da Contabilidade no ICMS Brasileiro: os impactos da convergência às normas contábeis internacionais e do projeto SPED - Sistema Público de Escrituração Digital).

A metodologia adotada em nossa pesquisa parte do pressuposto filosófico da necessária tridimensionalidade da interligação fato-norma-valor. Cabe pontuar que a visão filosófica da interligação fato-norma-valor não é nova no Direito Tributário. Tal visão jurídico-filosófica foi amplamente estudada e difundida no Brasil pelo Magnânimo Professor Miguel Reale para quem “a norma jurídica, assim como todos os modelos jurídicos, não pode ser interpretada com abstração dos fatos e valores que condicionaram o seu advento, nem dos fatos e valores supervenientes, assim como da totalidade do ordenamento em que ela se insere, o que torna superados os esquemas lógicos tradicionais de compreensão do direito (...)" ${ }^{\prime 14}$.

Infelizmente com frequência parte da doutrina tem ignorado a conexão e a interrelação do direito tributário com outras ciências, como é o caso das ciências contábeis, por entender que se trata de conhecimento extrajurídico (de meras questões de fato ou de valores extrajurídicos), se fechando no casulo da norma estritamente jurídica. Em verdade, as ciências contábeis e a própria economia possuem grande interação com o direito tributário, especialmente no campo dos valores e dos fatos, mas inclusive no campo da própria norma jurídica. Mesmos os estudos tributários que pretendam estudar tão somente a norma jurídica, não poderão ignorar a contabilidade, especialmente nos casos em que a norma jurídica se reporta a conceitos da área das ciências contábeis.

${ }^{14}$ REALE, Miguel. Teoria Tridimensional do Direito, 5a ed., São Paulo: Saraiva, 1994, p. 60-63. 


\section{PARTE C - CONCLUSÕES DA TESE CAPÍTULO 7 - CONCLUSÕES E TESES.}

1. O presente trabalho considerando os planos funcionais da contabilidade para o direito tributário sob o enfoque do ICMS brasileiro analisou as seguintes funções: a) a contabilidade ou escrituração contábil (livros e registros contábeis) como obrigação acessória ao cumprimento da obrigação tributária (cujo exemplo mais notório é a obrigação de entrega do SPED-ECD que permite aos Fiscos ter acesso aos livros e registros contábeis e fiscais das empresas por meio eletrônico); b) a contabilidade como elemento integrante da RMIT - Regra Matriz de Incidência Tributária, analisando-se especificamente no ICMS os efeitos tributários da nova contabilidade brasileira (padrão internacional). Os capítulos dois e três foram propedêuticos sobre os temas da convergência ao novo padrão contábil e dos principais contornos jurídicos e contábeis do ICMS. Portanto, são apresentadas as seguintes conclusões da tese, no que concerne aos capítulos quatro a seis:

\section{$1^{a}$ PARTE das CONCLUSÕES - A CONTABILIDAdE COMO OBRIGAÇÃo ACESSÓRIA - PROJETO SPED.}

No que concerne ao Projeto SPED e a utilização da contabilidade como obrigação acessória ao cumprimento da obrigação tributária no ICMS

2. Os fiscos são usuários relevantes da informação contábil gerada pelo SPEDECD, de modo que a obtenção da Escrita Contábil Digital - ECD no âmbito do Projeto SPED, sob a abordagem da teoria contratual da firma (ou da denominada "teoria da contabilidade e do controle"), é uma forma harmônica de informar ao fisco os inputs e outputs da firma, para que o fisco saiba que a empresa cumpre o seu papel perante o governo (e a sociedade) e que paga adequadamente os tributos conforme o "contrato" socialmente e legalmente firmado, que no direito tributário pelo primado da legalidade está esmiuçado na legislação tributária.

3. Quanto aos custos de conformidade do SPED, o Fisco estadual já abandonou diversas obrigações acessórias como o AIDF (autorização de impressão de documentos fiscais, que foi extinto após a Nota Fiscal eletrônica), os arquivos fiscais do SINTEGRA que são substituídos pela EFD-ICMS/IPI do SPED, mas espera-se que se caminhe os projetos de extinção da GIA de ICMS efetivamente durante o ano de 2017 de modo que no âmbito do ICMS até o ano de 2018 haja a efetiva substituição das obrigações 
acessórias de declaração mensal do ICMS denominadas de GIA-ICMS (Guia de Informação e Apuração do ICMS) pelos blocos constantes no SPED, ao menos no Estado de São Paulo e nos principais Estados. Portanto, existe ainda um grande desafio a todos os fiscos (federal, estadual e municipal). Quanto ao ICMS o fisco deve buscar na medida do possível tornar mais prático e simples a EFD-ICMS/IPI para que realmente haja um ganho para os contribuintes em termos de diminuição da complexidade e tempo para se preencher todas as informações necessárias ao Fisco estadual. Como pontuamos, o cumprimento da adoção e implementação do SPED trouxe custos de conformidade para as empresas, que terão que ser compensados pela justa expectativa de extinção das mais variadas obrigações acessórias tributárias nas várias esferas de governo e por uma maior racionalidade dos fiscos na exigência das informações contábeis e fiscais.

4. Quanto à administração de riscos fiscais do SPED para as empresas, a implementação do SPED impacta a rotina do departamentos fiscais das empresas além de ampliar o foco no risco fiscal, uma vez que o risco fiscal preexistente em face da complexidade do cenário tributário brasileiro, é ampliado e "agravado" neste novo conceito de obrigações acessórias fiscais e contábeis no formato eletrônico, seja pelo aumento das informações que são prestadas, seja pelo aumento do potencial de detecção pelas auditorias e fiscalização, ou seja, ampliando-se a possibilidade de autuação desta empresas. No âmbito do ICMS, o advento do Projeto SPED certamente potencializa sim o risco das empresas serem autuadas pelo fisco estadual. De qualquer forma, em nossa visão, não podemos ser ingênuos e pensar que todos os riscos fiscais são nocivos. O SPED proporciona também um aparato tecnológico que visa o combate efetivo à sonegação e por meio das documentações fiscais e contábeis eletrônicas propicia uma ampliação da fiscalização, especialmente na seara das auditorias contábeis com fins fiscais.

5. Cada vez mais é sensível a informação fiscal e contábil que as empresas contribuintes fornecem ao Fisco, e é extremamente essencial que o departamento contábil e fiscal destas empresas tenham certeza de que estão transmitindo uma escrita contábil (ECD) e fiscal (EFD) livre de erros e incorreições. Isto porque, eventualmente caso sejam fornecidos ao Fisco informações incompletas ou com erros, isto poderá trazer dissabores tanto à empresa quanto ao fisco, no caso de serem utilizados estes dados na construção de autuações fiscais em auditorias contábeis.

6. Nas auditorias contábeis (estaduais) são encontradas irregularidades contábeis na escrita comercial e nas demonstrações financeiras das empresas e que podem acarretar a autuação por presunção de omissão de operações tributáveis pelo ICMS, 
conforme os artigos 509 e 509-A do RICMS/SP. Ou seja, vimos que certas fraudes contábeis (isto, se houver realmente dolo da empresa) ou mesmo erros e incorreições contábeis (que aparentemente seriam "apenas" problemas de imperfeições na contabilidade financeira empresarial), podem criar situações graves de risco fiscal, inclusive com autuação no ICMS (e não apenas no IRPJ na sistemática lucro real), por meio de presunções legais da legislação tributária do ICMS que foram inspiradas na legislação do IRPJ e que visam "descobrir" ou desvelar o reconhecimento de receitas que estavam ocultas do fisco (gerando presunção de que ocorrem operações mercantis que não foram tributadas pelo ICMS).

7. A disponibilização de inúmeras informações eletrônicas pelo SPED aos fiscos de todas as esferas federativas certamente traz impactos no lançamento tributário e na própria fiscalização tributária pois abre uma possibilidade sem precedentes de uma ampliação de lançamentos tributários de ofício, antes do decurso do prazo de homologação tácita. Os fiscos previamente já estão de posse de uma imensa gama de informações contábeis e fiscais do contribuinte por meio do SPED (ECD e EFD) e já podem manipular uma imensa gama de informações e esta fase inicial de seleção que antes contava com informações parciais e parcos indícios de sonegação, já podem se transformar tecnicamente numa verdadeira auditoria contábil-fiscal, sem nem sequer o contribuinte ser notificado.

8. A autuação fiscal elaborada nesta fase pré notificatória do contribuinte deve se pautar pelo princípio da razoabilidade, que no âmbito estadual paulista está insculpido no rol de princípios administrativos (artigo $4^{\circ}$ da Lei Estadual 10177/1998 que rege o processo administrativo estadual). A legislação tributária atual não permitiria uma auditoria contábil-fiscal sofisticada, ainda que disponíveis as escritas fiscal e contábil (EFD e ECD), sem que haja uma notificação prévia do contribuinte do início do procedimento fiscal, inclusive com questionamentos sobre dúvidas da fiscalização tributária e pedido de documentos que evidenciem os lançamentos que estão sob dúvida. Por mais que a contabilidade (escrita comercial) e a escrita fiscal já estejam disponíveis ao Fisco por meio do SPED, só com uma análise da documentação suporte que lastreia aqueles lançamentos contábeis e fiscais, é que se pode ter por devidamente documentadas as situações mais complexas a serem imputadas num auto de infração.

9. Ao nosso ver, é preciso sim o respeito à legislação tributária em matéria de fiscalização tributária, mas o aplicador (o agente ou auditor fiscal) deve agir com proporcionalidade e ponderação caso a caso. Neste sentido, vejo com exagero formalista aqueles que advogam pelo total óbice à lavratura de uma autuação fiscal com comunicação 
direta ao contribuinte, sem que haja notificações e processo fiscalizatório repleto de notificações e respostas dialéticas. Nem toda autuação fiscal comunicada diretamente ao contribuinte, sem período de fiscalização tributária prévia, é nula a priori. O direito ao contraditório e ampla defesa do contribuinte, no período que antecede à lavratura do auto de infração deve ser sopesado dentro dos critérios de razoabilidade e proporcionalidade. Algumas autuações fiscais são simples e pontuais do ponto de vista técnico-jurídico e se comprovam de maneira cabal pela documentação eletrônica já disponibilizada ao Fisco. Nestes casos, a própria autuação fiscal pode ser feita de maneira célere pelo simples cruzamento das informações eletrônicas já disponibilizadas pelo contribuinte. Dessa forma, caso o auditor fiscal não pretenda aprofundar a fiscalização e só queira lavrar esta autuação pontual, que já está documentada neste período de pré-análise do contribuinte, pode perfeitamente comunicar o contribuinte da autuação fiscal no seu primeiro contato, desde que evidentemente a documentação (normalmente eletrônica) já disponível seja hábil a provar a acusação fiscal, e o relato circunstanciado da autuação fiscal seja claro o suficiente para que o contribuinte possa se defender na sua primeira defesa no âmbito do processo administrativa.

10. Adicionalmente, os novos padrões contábeis e especialmente o Pronunciamento Contábil CPC n 07 -Subvenção e Assistência Governamentais traz normas de "disclosure" das demonstrações financeiras que permitem um melhor reconhecimento, mensuração e evidenciação das subvenções governamentais, inclusive no que concerne a programas de benefícios fiscais estaduais de ICMS. Ao nosso ver, sendo também os fiscos estaduais usuários da informação contábil, os mesmos poderiam se utilizar melhor de demonstrações financeiras publicadas, bem como de informações constantes da escrita contábil/comercial das empresas (especialmente contidos na ECD Escrita Contábil Digital) para poder identificar adequadamente benefícios fiscais que possam estar sendo usados de forma inconstitucional e que possam impactar em autuações de glosa de crédito de ICMS.

11. Adicionalmente o novo padrão IFRS trouxe algumas situações dessíncronas entre o reconhecimento da receita contábil e o momento do fato gerador do ICMS. O reconhecimento contábil da receita de vendas de mercadorias em situações de dessincronização com o fato gerador do ICMS (exemplo dos ativos biológicos), ocasionam maiores dificuldades e riscos nos processos de auditoria contábil com fins tributários. O Fisco deve estar atento nas auditorias contábeis com finalidade tributária na análise de cada caso concretos, pois a fiscalização na execução de auditorias contábeis deverá atentar para 
a possível dessincronização do momento de emissão de notas fiscais do momento de reconhecimento contábil das receitas. Por exemplo, no caso dos Ativos Biológicos é natural o aumento (ou redução) do resultado contábil apurado, decorrente do ajuste a valor justo efetuado contra o resultado do exercício. Ainda que contabilmente haja a antecipação de receitas para a Pessoa Jurídica, a tributação do ICMS deve continuar acompanhar o momento da saída da mercadoria. Ou seja, a tributação do ICMS deve-se dar no momento da alienação do produto agrícola ou agroindustrial, com eliminação dos efeitos apontados. De qualquer forma, a fiscalização estadual deverá atentar para os movimentos e divergências naturais (que não implicam em diferenças por levantamentos fiscais), mas também para a possibilidade de artifícios do contribuinte (postergação do pagamento do imposto, ou mesmo reconhecimento de receitas de "caixa dois" - de valores recebidos à margem da contabilidade).

\section{$2^{a}$ PARTE dAS CONCLUSÕES - CONVERGÊNCIA CONTÁBIL ÀS NORMAS INTERNACIONAIS (IFRS) - EFEITOS TRIBUTÁRIOS DO NOVO PADRÃO CONTÁBIL NO ICMS.}

No que concerne à Consideração Econômica, à importância das classificações econômico-contábeis juridicizadas para o direito tributário, e à possiblidade de positivação na legislação tributária de conceitos econômicos-contábeis.

12. As classificações dos tributos trazidas pela economia e pela contabilidade importam ao direito tributário, na medida em que existem situações em que estas classificações foram juridicizadas pelo legislador tributário (foram apresentados dois exemplos paradigmáticos da utilização de critérios classificatórios contábeis e econômicos pelo legislador tributário: a restituição do indébito tributário nos tributos indiretos (CTN) e inclusão do ICMS na base de cálculo das contribuições do PIS e COFINS, em que estas classificações foram contempladas pelo legislador tributário).

13. As classificações econômicas e contábeis dos tributos também podem ser úteis para a sociedade e para a administração tributária, em geral, nas diversas esferas (federal, estadual e municipal), no sentido de ser um critério pragmático de verificação do cumprimento do pacto federativo (exemplo das contribuições do PIS-COFINS e da invasão “econômica” da União na competência tributária constitucional dos Estados e Municípios).

14. A classificação dos tributos em incidentes sobre atos/fatos ou negócios "formais" versus "econômicos" é relevante no direito brasileiro e foi recepcionada em 
nosso CTN, sendo que o direito tributário brasileiro ganhou uma progressiva e gradual autonomia em relação ao direito civil, na medida em que foi se operando uma gradual libertação das hipóteses tributárias dos principais tributos do jugo dos "atos e negócios jurídicos" de direito civil (dois exemplos: o paradigma da mudança e abandono do antigo IVC, que era um tributo que incidia sobre negócios jurídicos, para o ICMS, que passou a contemplar na hipótese tributária atos e fatos que denotam a circulação econômica das mercadorias; o Imposto de Renda, cujo fato gerador consiste na aquisição da disponibilidade econômica ou jurídica de renda, assim entendido o produto do capital, do trabalho ou da combinação de ambos e de proventos de qualquer natureza (acréscimos patrimoniais), sendo que, em nossa opinião o CTN elege em verdade como principal critério da renda tributária a "disponibilidade econômica" adotando um conceito econômico de acréscimo patrimonial, embora possa estar adstrito ao conceito de disponibilidade meramente jurídica).

15. A consideração econômica consiste em reconhecer que o legislador tributário possa tomar situações econômicas no momento de elaborar a materialidade de determinados tributos, sendo que deve ser entendida no sentido de ser uma forma de interpretação teleológica dos conceitos adotados na legislação tributária, quando se entende que tais conceitos têm perfil de natureza econômica (juridicizados pela lei). A consideração econômica também compreende a qualificação da relação entre a hipótese tributária e a situação fática, ou seja, diz respeito ao momento da aplicação e subsunção dos fatos concretos à norma jurídica.

16. A consideração econômica não apregoa a utilização indiscriminada de quaisquer critérios econômicos e contábeis na interpretação e aplicação do direito tributário, mas reconhece a possibilidade do legislador tributário conscientemente utilizar critérios econômicos e contábeis na definição da materialidade e hipótese de incidência dos tributos.

17. O legislador tributário pode se utilizar diretamente de conceitos econômicos e contábeis que entender adequados para a tributação. Nesse sentido, estes conceitos deixam de ser estritamente econômicos ou contábeis para também serem jurídicos, na medida em que se reconheça sua positivação.

No que concerne às Regras Contábeis como normas jurídicas e sua relação com o Direito Tributário. Normas jurídico-contábeis de direito privado (com conteúdo cada vez mais econômico) podendo ser utilizadas pelo legislador tributário. Relação das 


\section{normas contábeis (de direito privado) com as normas tributárias, sob o enfoque dos artigos 109 e 110 do CTN.}

18. As denominadas "regras contábeis" (a contabilidade) tem um caráter de juridicidade que lhes é próprio e que as diferenciam dos conteúdos, conceitos e institutos meramente econômicos, sendo que a contabilidade (no sentido das regras de contabilidade financeira) é norma cogente e que integra o direito comercial e societário brasileiro, sendo mais adequado do ponto de vista jurídico se falar em "normas contábeis" do que meramente se falar em "regras contábeis".

19. Não há dúvidas atualmente sobre a necessidade da devida observância das regras contábeis materializadas, especialmente nos pronunciamentos do $\mathrm{CPC}$, que são verdadeiras normas jurídicas embasadas e autorizadas pela legislação societária brasileira e de observância obrigatória para as empresas e contabilistas.

20. Com o advento desta nova contabilidade internacional, internalizada no Brasil pelos pronunciamentos do CPC, adentram na Contabilidade brasileira a utilização de novos critérios contábeis mais aderentes com a essência econômica. O que se demonstra com o novo padrão contábil IFRS é que a contabilidade brasileira (as normas/regras contábeis de contabilidade financeira) vem se distanciando dos conceitos jurídicos tradicionais (de direito civil) e vem fazendo uma aproximação com a economia, através de institutos contábeis (normas jurídicas) que são mais aproximativos dos conceitos econômicos.

21. Ou seja, atualmente temos um novo padrão de conceitos contábeis, verdadeiras normas jurídicas, que implicam gradualmente no afastamento das regras contábeis brasileiras do direito civil e de uma aproximação destas normas jurídicas com a Economia. Assim, o legislador tributário, em muitos casos, faz referências a estes conteúdos, conceitos e institutos contábeis (os quais são normas verdadeiras normas jurídicas carregadas de grande fluidez de conteúdos oriundos da Economia).

22. Deste modo, a repelência à consideração/econômica em direito tributário, não é capaz de refutar um fato inexorável: de que o legislador tributário, por vezes, se utiliza de conceitos e institutos contábeis (que absorvem conceitos econômicos) já juridicizados no direito privado. Fato é que, gostem ou não os juristas e tributaristas, e tenham tal ou qual visão doutrinária, o fato inegável é de que o direito tributário e a legislação tributária podem fazer referências a normas jurídicas de direito privado, e as normas contábeis estão plenamente juridicizadas no ordenamento jurídico brasileiro. 
23. Na prática a discussão da possibilidade de interpretação/consideração econômica acaba ficando mais fraca, e cada vez mais "tênue" em relação ao tema da utilização de conceitos contábeis pelo legislador tributário, pois aqui o legislador não "bebe" diretamente na fonte dos conteúdos das Ciências Econômicas nem mesmo nas fontes de Ciências Contábeis de forma "crua"; e sim na fonte da norma jurídico-contábil (integrante do Direito Privado - comercial e societário) e com o processo de convergência internacional da contabilidade (padrão IFRS) os conceitos versado nas normas contábeis se aproximam do conteúdo econômico. O fato inegável é de que o direito tributário e a legislação tributária podem fazer referências a normas jurídicas de direito privado, e as normas contábeis (padrão IFRS) estão plenamente juridicizadas no ordenamento jurídico brasileiro.

24. Ao nosso ver, o artigo 109 do CTN dispõe basicamente que o direito tributário possui autonomia, no sentido que os institutos, conceitos e formas de direito privado poderão ser adaptados para fins de tributação, fazendo com que estes assumam significados distintos em relação à sua definição no campo jurídico de origem (no direito privado). Mas é evidente que a possibilidade de alteração dos conteúdos e conceitos privados para fins tributários, vai encontrar limites na própria competência tributária definida constitucionalmente, aspecto este realçado pelo artigo 110 do CTN, que funciona como um "freio" ao legislador tributário, que não pode deformar os conceitos de direito privado que estejam expressos na ordem tributária de patamar constitucional.

25. Em nosso entendimento quando o legislador tributário utiliza conceitos contábeis, pela autonomia que o direito tributário desfruta, o legislador pode alterar este conceito e criar um conceito próprio para fins tributários que seja diferente daquele conceito na área de origem das Ciências Contábeis. Todavia, se não o fizer, ao incorporar um conceito privado que é o caso dos institutos regrados pelas normas contábeis, deve aceitar este conceito conforme normatizado pelas normas jurídicas societárias e contábeis, ao menos como o ponto de partida da interpretação.

26. Isto não significa dizer que os conceitos de contabilidade quando mencionados pelo legislador tributário irão adentrar forçosamente no sistema tributário da forma como regulado no direito privado (comercial/societário) sem nenhuma avaliação de compatibilidade com o sistema jurídico vigente. É evidente que mesmo quando se reconheça que o legislador tributário se reportou diretamente a um conceito ou instituto de direito privado, caberá a intepretação sistemática considerando especialmente os princípios de direito tributário e as regras constitucionais de competência tributária. 
27. Em nossa opinião, há de se tomar cuidado com os efeitos tributários advindos do uso de um conceito contábil diretamente na legislação tributária, já que no caso de haver uma mudança do conceito de direito de privado (no caso uma mudança nas normas jurídico-contábeis e societárias) esta pode impactar sim na regra matriz de incidência do tributo que a utilizou, seja no caso do IRJP, das contribuições do PIS e COFINS, seja no caso do ICMS (nas situações pontuais demonstradas ao longo do capítulo seis).

28. Toda a discussão sobre a neutralidade tributária travada no contexto da mudança do padrão contábil brasileiro para o padrão internacional IFRS, pressupõe a preocupação em se analisar na legislação tributária (IRPJ, PIS, COFINS e por nós, no ICMS) as referências diretas que o legislador tributário fez a institutos e conceitos contábeis, especialmente quando a remissão a estes conceitos estiverem inseridas dentro de algum dos elementos constantes da regra-matriz de incidência destes tributos. Pois neste caso, o ponto inicial da interpretação é o critério dinâmico, que tem como ponto de partida a possibilidade da mudança do conceito contábil causar efeitos tributários nestes tributos, sendo que o não reconhecimento destes efeitos só será possível por meio de uma interpretação estática que esteja amplamente embasada em ofensas muito claras ao

princípios constitucionais e às competências tributárias constitucionais. Portanto, a mutação conceitual dos conceitos contábeis na legislação tributária é a regra, e a estática destes conceitos é a exceção.

29. Conclui-se assim que, toda a vez que o legislador tributário não quiser se sujeitar aos efeitos da mudança das regras contábeis de direito privado (no caso de ter utilizado estes conceitos contábeis na regra-matriz de incidência de um tributo), deve por meio da autonomia do direito tributário que lhe é conferida, modificar estes conceitos expressamente na legislação tributária, prevendo de forma expressa a anulação da mudança dos efeitos contábeis, como o fez em âmbito federal com a publicação da Medida Provisória $n^{\circ} 627 / 2013$, convertida na Lei $n^{\circ} 12.973 / 2014$.

\section{A regra-matriz de incidência dos tributos e a possibilidade de inserção de elementos contábeis.}

30. A importância da utilização de conteúdos, institutos e conceitos contábeis (embasado nas normas jurídico-contábeis juridicizadas no direito privado brasileiro) ganha especial relevo quando tais conteúdos, institutos e conceitos são utilizados pelo legislador tributário num dos componentes da denominada regra-matriz-de-incidência tributária- 
RMIT de um tributo, ou, seja: a) como elemento integrante do "fato gerador"/hipótese de incidência do tributo (quando o elemento contábil for captado pelo direito tributário no antecedente da hipótese de incidência tributária de um tributo); b) como elemento quantitativo da base de cálculo do tributo (nos casos em que o direito tributário elege um elemento quantitativo mensurado pela contabilidade no consequente da hipótese de incidência tributária de um tributo).

31. O legislador tributário pode adotar conceitos contábeis na regra-matriz de incidência dos tributos (no antecedente e no consequente), não apenas no IRPJ e PISCOFINS, mas em outros tributos, inclusive, no ICMS (ainda que em situações pontuais). Neste caso, o legislador pode decidir modificar ou não o conceito utilizado de direito privado das normas contábeis apenas para fins dos seus efeitos tributários por conta da autonomia do direito tributário. Todavia, naquilo que o conceito de direito contábil não é alterado, a legislação tributária deve seguir as normas de direito contábil (direito privado) quanto à definição, reconhecimento, mensuração conforme aqueles institutos contábeis no seu campo origem, e este será o ponto de partida da interpretação e aplicação da legislação tributária.

32. No âmbito da legislação tributária do ICMS, não houve esta preocupação por parte dos legisladores tributários (federal e estadual) em promover uma neutralização dos efeitos tributários do novo padrão contábil, de modo atualmente se suscita dúvidas técnicas sobre uma gama de assuntos do ICMS atrelados aos possíveis efeitos da convergência ao padrão contábil internacional (IFRS).

33. O ICMS apenas pontualmente faz referência a conceitos contábeis, mas quando o faz podem sim haver impactos tributários advindos do novo padrão contábil (IFRS), pois uma vez que estes critérios foram utilizados na RMIT do ICMS, irão espraiar seus efeitos para a aplicação da norma tributária. De outro modo, há situações que envolvem o ICMS que não guardam conexão com conceitos contábeis e estas situações não serão impactadas pela mudança de padrão das normas contábeis. Os exemplos que foram trazidos no capítulo seis (6) são os atualmente mais discutidos e procuramos fazer esta separação prática com este embasamento teórico: apontando em que situações há impacto das normas contábeis (IFRS) e onde não há este impacto.

\section{Parte prática/pragmática: análise dos efeitos tributários da nova contabilidade brasileira (padrão internacional) no ICMS}


34. Por parte da Receita Federal do Brasil houve um preocupação interna dos auditores fiscais em estudar o tema destes impactos tributários destas normas contábeis internacionais (não apenas no IRPJ, mas também sobre a tributação indireta, especialmente no que concerne as contribuições de PIS e COFINS), o que redundou em diversos projetos legislativos, que foram implementados no âmbito federal, justamente com a finalidade de se preservar a denominada "neutralidade tributária", tendo sido tratado pontualmente pelo legislador federal de forma bastante técnica e específica o tratamento tributário necessário para anular cada um destes efeitos tributários que foram identificados pelo Fisco Federal, o que redundou especialmente na Lei Federal 12.973/2014, sendo que a neutralidade tributária já vinha sendo adotada com o RTT, instituído pela Lei no 11.941/2009.

35. No âmbito da legislação tributária do ICMS, não houve esta preocupação por parte dos legisladores tributários (federal e estadual) em promover uma neutralização dos efeitos tributários do novo padrão contábil, de modo atualmente se suscita dúvidas técnicas sobre uma gama de assuntos do ICMS atrelados aos possíveis efeitos da convergência ao padrão contábil internacional (IFRS).

36. Uma questão de suma importância, a ser analisada conceitualmente e na prática, é se o ICMS estaria ou não garantido pelo chamado Princípio da "Neutralidade Tributária" ou se sua tributação sofreria alguns efeitos com os novos critérios contábeis, uma vez que a Lei 11.941/2.009 disciplinou a neutralidade apenas os tributos federais (principalmente Imposto de Renda - Lucro Real, e também estende estes efeitos à CSLL, PIS e COFINS) e que também o ICMS não teve seus efeitos tributários tratados ou anulados na Lei Federal 12.973/2014. A nossa tese defende ao longo do desenvolvimento dela que há conceitos contábeis que também afetam a tributação do ICMS, e no capítulo seis procuramos demonstrar os possíveis impactos destas normas tributárias, atrelando sempre que possível a casos práticos, devidamente embasados na doutrina tributária e contábil.

37. Há a urgente necessidade do fisco estadual em algum momento afastar os ricos e evitar a insegurança jurídica, e seguindo o exemplo da Receita Federal, estabelecer um campo de neutralidade fiscal de modo a preservar o tributo (ICMS) dos efeitos da convergência contábil. Este olhar atento dos Fiscos Estaduais deve consistir, num primeiro aspecto, da verificação do risco fiscal advindo da convergência às normas contábeis internacionais (pontos de divergência ou de insegurança jurídica) inerente à não realização de créditos tributários (que podem ser constituídos mediante a lavratura de AIIMs) em função da divergência de critérios (contábil x fiscal) e, em um segundo aspecto, do 
estabelecimento de estratégias necessárias à harmonização (fisco x contribuinte) quanto ao tratamento das informações econômicas disponibilizadas pelas empresas para fins da correição técnica das auditorias contábeis com finalidade fiscal.

38. No capítulo seis analisamos os principais efeitos e desafios trazidos pelo processo de convergência contábil internacional, quando da aplicação, pelo contribuinte, de novos critérios de reconhecimento, mensuração e evidenciação de fatos contábeis inseridos no sistema contábil brasileiro pelas normas contábeis internacionais (as IFRS), e que em confronto com as normas existentes na legislação tributária no âmbito do ICMS podem impactar na determinação ou na formação da base econômica e jurídica de incidência deste imposto. Assim, foram apresentadas as principais situações que envolvem o risco fiscal ${ }^{509}$, ou seja, os reflexos da inserção em nosso sistema contábil brasileiro de novos critérios internacionais adotados pelos contribuintes relativos ao reconhecimento, mensuração e evidenciação de fatos e elementos contábeis e que podem impactar na formação ou determinação da base econômica e jurídica de incidência do ICMS (regras contábeis que conflitam ou que interferem sobre a legislação tributária do ICMS, notadamente materializada no RICMS/SP e que podem, em tese, oferecer "risco" ou divergência interpretativa a favor do Fisco ou do contribuinte capaz de impactar na base de arrecadação ou em algum aspecto da regra-matriz de incidência do ICMS).

39. Após analisarmos as principais situações principais de divergência (ou do denominado "risco fiscal") entre os critérios contábeis e os critérios fiscais do ICMS (e que também estão representadas no Apêndice da Tese) chegamos às seguintes conclusões sobre as situações práticas/pragmáticas:

40. O Valor Realizável Liquido (VRL) dos Estoques e a Base de Cálculo do ICMS em situacões específicas (por exemplo: nas transferências de mercadorias; operação de industrialização com cobrança de mercadorias e serviços): Em nossa opinião, cada situação específica deverá ser avaliada com base na legislação tributária daquela situação. Todavia, toda vez que a legislação tributária do ICMS delegar a atribuição da base de cálculo ao conceito genérico de custo (que é atribuível pela contabilidade), se não houver uma criação específica e uma delimitação daquele conceito

\footnotetext{
${ }^{509}$ Risco Fiscal aqui entendido como divergências e riscos interpretativos sobre algum dos aspectos inerentes ao fato gerador (ou regra matriz de incidência) do ICMS. Ou seja, as principais divergências entre os critérios contábeis e os critérios fiscais do ICMS que podem ensejar impactos tributários na arrecadação do ICMS. A palavra "risco" aqui está sendo utilizada no sentido de insegurança jurídica, embora em parte das situações apresentadas possa representar um impacto favorável ao contribuinte ou ao Fisco. Ou seja, o risco é aqui tratado como a possibilidade das normas tributárias alterarem o status quo de algum aspecto essencial do ICMS. Já em outras situações que serão vistas, o novo padrão contábil poderá resultar em um aumento da tributação do ICMS.
} 
para fins específicos tributários, deverá ser utilizado o critério adotado pela contabilidade. Assim, por exemplo, nas situações de transferência interestaduais de mercadorias industriais, em nosso entender ao legislador complementar na Lei Kandir relacionar a base de cálculo ao conceito de "custo da mercadoria produzida", deverá aceitar este conceito da forma como está normatizado pelas regras contábeis, e havendo a obrigação jurídica da entidade adotar o custo histórico ou o valor realizável líquido, no caso de ser adotado este último, ainda que este seja menor que o custo histórico, tal método contábil poderá refletir na base de cálculo do ICMS. Este nosso entendimento é coerente com a parte teórica da presente tese (capítulo cinco), em que pelo nosso entendimento quando o legislador tributário utiliza conceitos contábeis, pela autonomia que o direito tributário desfruta o legislador pode alterar este conceito e criar um conceito próprio para fins tributários. Todavia, se não o fizer, ao incorporar um conceito privado que é o caso dos institutos regrados pelas normas contábeis, deve aceitar este conceito conforme normatizado pelas normas jurídicas societárias e contábeis. Desse modo, vislumbro sim, em hipóteses específicas, a influência do instituto do VRL- valor realizável líquido na formação da base de cálculo do ICMS, nas hipóteses em que o custo contábil puder servir de parâmetro para a mensuração do aspecto quantitativo do tributo.

41. Mensuração dos estoques e a base de cálculo do ICMS nas transferências (e recebimentos) de mercadoria para (de) outra unidade da federação: Ao analisarmos e compararmos os critérios da contabilidade com os critérios fiscais do ICMS, notamos que há divergência entre os critérios, uma vez que os critérios contábeis se focam nos seguintes aspectos: a) há a possibilidade de redução do valor do estoque ao seu valor realizável líquido - Custo Histórico ou VRL, dos dois o menor na Contabilidade (tema já analisado no subitem anterior - Item 9 do Pronunciamento CPC $n^{\circ} 16$ ); b) adoção do critério de valoração do estoque contábil por PEPS ou preço médio - Item 25 do Pronunciamento CPC $n^{\circ} 16$; c) Mensuração de estoque: na contabilidade deve incluir todos os custos de aquisição, de transformação, bem como outros custos incorridos para trazer os estoques à sua condição e localização atuais - Item 10 do Pronunciamento CPC n ${ }^{\circ} 16$. Por sua vez, no ICMS os critérios fiscais normalmente utilizados tratam estes mesmos aspectos de forma distinta, da seguinte forma: a) se apregoa a adoção do custo histórico (ainda que não de maneira expressa) na base de cálculo do ICMS nas transferências (como se infere do $\S 4^{\circ}$ do artigo 13 da Lei Complementar 87/1996, em que se adota o valor de entrada mais recente para fins de empresas comerciais e o custo da mercadoria produzida para fins de empresas industriais); b) se apregoa a adoção do critério de UEPS como base de cálculo 
do ICMS pela própria lei complementar, em que se adota o valor de entrada mais recente para fins de empresas comerciais; c) aceitar-se-ia numa interpretação meramente literal da Lei Kandir como "custo da mercadoria produzida" apenas: matéria-prima, material secundário, mão-de-obra, e acondicionamento.

42. Lembramos que o legislador tributário muitas vezes utiliza termos muito atécnicos, como foi o caso da elaboração do inciso I do $\S 4^{\circ}$ do artigo 13 da Lei Complementar 87/1996, em que nas transferências de mercadorias realizadas por empresas comerciais a base de cálculo foi definida na Lei Kandir como sendo "o valor correspondente à entrada mais recente da mercadoria”. Muitos intérpretes desta norma já vislumbraram duas referências ligeiramente distintas quanto à determinação da base de cálculo: i) por uma visão contábil o termo "valor da entrada mais recente”, ainda que usado de forma coloquial, poderia corresponder ao custo da mercadoria apurado pelo método contábil UEPS (último que entra, primeiro que sai); ii) por uma visão estritamente fiscal (do ICMS), corresponderia ao valor total da Nota Fiscal de aquisição desta mercadoria (registrado no Livro Registro de Entradas do ICMS), e que corresponda a aquisição mais recente desta mercadoria que será transferida. Nos filiamos à primeira interpretação, todavia, a posição atual do fisco paulista está calcada na segunda interpretação.

43. Em relação mercadorias industrializadas, interpretando o artigo 13, parágrafo $4^{\circ}$, inciso II, da Lei Complementar 87/1996, compreendo que da forma que o dispositivo foi construído pelo legislador, dá a entender que o mesmo apenas quis ser didático e trazer exemplos daquilo que comporia o "custo de produção", trazendo exemplos embasados na doutrina contábil, contudo sem ser exaustivo. Dessa forma, compreendo adequada a intepretação conferida pelo Fisco paulista na Decisão Normativa CAT 05/2005, devendo necessariamente o contribuinte industrial para formar a base de cálculo do ICMS nestas transferências interestaduais adotar a contabilidade de custos com base nos princípios e normas contábeis vigentes, devendo, portanto, adotar o conceito de "custo de produção" adotado nas normas contábeis.

\section{Mensuracão da Receita, apuracão do Ajuste a valor presente (AVP) e a}

Base de Cálculo do ICMS nas vendas a prazo: Em nosso entendimento no presente caso, especificamente com relação ao instituto contábil do "Ajuste a Valor Presente", vislumbramos que especificamente não há um potencial deste instituto vir a alterar a base de cálculo do ICMS, uma vez que a base de cálculo do ICMS na compra e venda mercantil é o valor da operação assim entendido como o preço daquele contrato. Para explicarmos 
nossa posição enfocamos que o instituto do AVP em verdade altera o conceito de "receita bruta" contábil, este sim, com potencial de alterar outros tributos indiretos, notadamente as contribuições de PIS-COFINS cuja base de cálculo é sim a Receita Bruta, e se não fosse a expressa menção da na Lei Federal 12.973/2014 em anular os efeitos tributários do AVP, haveria sem dúvida uma diminuição da base de cálculo das contribuições de PIS-COFINS sujeitas ao ajuste a valor presente da Receita Bruta. Embora em muitas situações se pudesse coincidir o valor do preço do contrato de compra e venda com o valor contabilizado na Receita Bruta, entendemos que estes conceitos não podem ser tomados como sinônimos, e com a introdução do mecanismo contábil do AVP passou a se ter uma dissociação entre os valores do preço do contrato de compra e venda a prazo e o valor da receita bruta contabilizada. Explico: o contrato de compra e venda a prazo pode prever o pagamento de $\mathrm{R} \$ 110.000$ daqui 4 meses, e pela aplicação do ajuste a valor presente, a receita bruta contabilizada a vista poderá ser de R \$100.000, com o reconhecimento ao longo do período dos \$10.000 a título de juros. Ocorre que a base de cálculo do ICMS não é a Receita Bruta e sim o valor estipulado no contrato de compra e venda mercantil (no caso a prazo), sendo que o próprio Código Civil (por exemplo, nos artigos 481, 487 e 491), autoriza o vendedor cobrar um preço que considere o crédito dado ao comprado em função de índices ou parâmetros que contemplem estes juros. Portanto, há de se reconhecer neste exemplo, que o preço a ser pago em data futura (no exemplo em 4 meses) é de R $\$ 110.000$, devendo neste caso a Nota Fiscal ser emitida com este valor, sendo esta a base de cálculo do ICMS (e não a receita bruta contabilizada pelo método de AVP no valor de R\$ 100.000). Nossa conclusão é coerente com o que viemos defendendo na parte teórica do presente trabalho. Não sendo a Receita Bruta um elemento juridicizado pela legislação tributária do ICMS, não há como reconhecer efeitos das novas normas contábeis (notadamente do instituto do AVP) na base de cálculo do ICMS, por ter a base de cálculo do ICMS na compra e venda se restringido ao valor da operação correspondente ao preço do negócio jurídico.

45. Ativo Imobilizado nas Concessões: Fica ao nosso ver claro, que o ICMS ao tempo em que foi editada a Lei Kandir conferiu o direito ao crédito ao denominado "Ativo Permanente" (nomenclatura contábil hoje desatualizada), mas que à época compreendia quatro subgrupos: Investimentos; Ativo Imobilizado; Ativo Intangível e Ativo Diferido (este último também extinto pelo novo padrão contábil). Tradicionalmente, após a convergência contábil internacional se reconhece que os ativos imobilizados dão direito ao crédito do ICMS, sendo que normalmente a rubrica de investimentos (não 
confere crédito de ICMS, pois diz respeito a participações societárias - não tributáveis por este imposto) e a rubrica de ativo intangível tradicionalmente não conferia crédito de ICMS, pois em geral, contemplava bens intangíveis que não haviam sido tributados por este tributo - ICMS (como é o caso de marcas, patentes, etc.). De qualquer forma, como vimos, com a nova forma de contabilização das concessões é possível que os antigos "ativos imobilizados" utilizados por estas concessionárias venham a ser contabilizados agora ora como ativos financeiros, ora como ativo intangível. Desse modo, em nosso sentir, se estes bens de infraestrutura forem contabilizados e amortizados como ativos intangíveis, no caso destes ativos, bens e equipamentos de grande porte terem sido anteriormente tributados pelo ICMS, haverá sim, a possibilidade de manutenção e fruição destes créditos de ICMS, uma vez que o antigo termo contábil materializado na Lei Kandir ("ativo permanente") agora substituído pelo termo "ativo não-circulante", poderia abarcar não apenas os ativos imobilizados, mas também os ativos intangíveis (desde que sobre estes houvesse incidido o ICMS).

46. Arrendamento Mercantil Operacional: Vislumbramos que o impacto maior é no arrendamento mercantil operacional, já que no arrendamento mercantil financeiro (independentemente da transferência ou não da propriedade jurídica) há a transferência substancial dos riscos e benefícios inerentes à propriedade de um ativo ao arrendatário. Já no arrendamento mercantil operacional, de acordo com o Pronunciamento Contábil CPC n ${ }^{\circ} 06$ - Arrendamento Mercantil não há a transferência substancial de todos os risos e benefícios inerentes à propriedade ao arrendatário, de modo que, este caso, o Ativo é reconhecido somente no Arrendador (e não na Arrendatária). Ainda de acordo com os itens 8, 33 e 49 do o Pronunciamento Contábil CPC n ${ }^{\circ}$ 06, sob o ponto de vista do arrendatário, o CPC 6 dispõe que os pagamentos da prestação do arrendamento mercantil segundo um arrendamento mercantil operacional devem ser reconhecidos como despesa e sob a ótica do arrendador, o ativo é de propriedade do arrendador, sendo que, além da receita, a arrendadora deve reconhecer também a depreciação do bem. Em nosso ver, um aspecto relevante para se analisar cada um destes casos (do arrendamento mercantil financeiro e operacional), é verificar com base na norma contábil, quem é o efetivo proprietário econômico daquele bem, e quem poderá reconhecer aquele ativo imobilizado como seu em seu balanço patrimonial. Ou seja, em cada caso específico deve ser avaliado os critérios contábeis estipulados no Pronunciamento Contábil CPC n 06 - Arrendamento Mercantil, cabendo verificar qual empresa possui de maneira efetiva a propriedade econômica representada pelos benefícios, riscos e controle desses bens. Isto porque a 
legislação tributária do ICMS ao tratar do ativo imobilizado fica sujeita ao regramento contábil vigente, de modo que só se pode conferir o crédito do ICMS, àquele contribuinte que possa de acordo com as normas jurídico-contábeis (notadamente do Pronunciamento $\mathrm{CPC} \mathrm{n}^{\circ} 27$ ) reconhecer este ativo imobilizado em seu balanço patrimonial.

47. Reconhecimento e Mensuracão do Ativo Imobilizado - Reposicão do Ativo Imobilizado (Pecas e Partes) e o Creditamento do ICMS: Em nosso entendimento, a interpretação fiscal estadual em alguns pontos acaba por extravasar o conteúdo da normatização contábil de bem do ativo imobilizado, que foi alterado no contexto do novo padrão contábil IFRS. Neste ponto enfatizo alguns aspectos constantes do próprio Pronunciamento CPC $\mathrm{n}^{\mathrm{o}} 27$ sobre o ativo imobilizado para embasar o direito (ou não) ao crédito do ICMS.

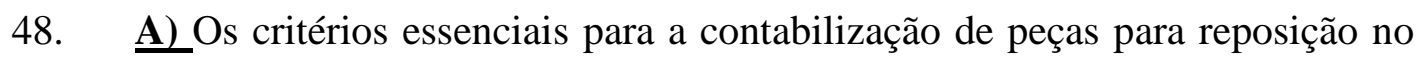
ativo imobilizado pressupõe ou que os sobressalentes, peças de reposição, ferramentas e equipamentos de uso interno serão utilizados por mais de um período; ou de que possam ser utilizados somente em conexão com itens do ativo imobilizado. Ou seja, nos termos do item 8 do Pronunciamento $\mathrm{CPC}^{\circ} 27$ o fato da peça de reposição ser utilizada num ativo imobilizado já constante do balanço da empresa (um equipamento industrial, por exemplo) permite que estas peças de reposição sejam contabilizadas como ativo imobilizado desde que preencham os requisitos de reconhecimento como ativo imobilizado (descrito no item 7 do Pronunciamento CPC $\mathrm{n}^{\circ} 27$ ), de que é provável que futuros benefícios econômicos associados ao item fluirão para a entidade; e que o custo do item possa ser mensurado confiavelmente. Neste caso, entendo que se preenchido estes requisitos e a peça de reposição puder ser considerado ativo imobilizado há de se reconhecer reflexamente na legislação tributária o direito ao crédito do ICMS.

49. B) Por outro lado, a norma contábil (item 12 do Pronunciamento CPC n 27) aponta que não se deve reconhecer no valor contábil de um item do ativo imobilizado os custos de sua manutenção periódica, sendo que esses custos são reconhecidos diretamente no resultado (como despesa nas demonstrações de resultado, quando incorridos). Ou seja, os custos da manutenção periódica (por ex.: custos de mão-de-obra, de produtos consumíveis, o custo de pequenas peças) que tenham a finalidade de "reparo e manutenção" de item do ativo imobilizado não configuram ativo imobilizado e são tratados como despesas no resultado. Portanto, as peças que possuam valores imateriais ou irrelevantes, e os produtos consumíveis no concerto ou reparo que digam respeito a manutenções periódicas devem ser tratados no ICMS como materiais de uso e consumo, 
portanto, sem direito ao crédito de ICMS como ativo imobilizado, pois pela própria norma contábil não podem ser contabilmente reconhecidos como ativo imobilizado.

50. C) Também observe-se que a norma contábil (itens 13 e 70 do Pronunciamento CPC $\mathrm{n}^{\circ} 27$ ) nas situações em que partes de alguns itens do ativo imobilizado podem requerer substituição em intervalos regulares (por exemplo, um forno pode requerer novo revestimento após um número específico de horas de uso) permite que a entidade reconheça no valor contábil do item do ativo imobilizado o custo de uma peça reposta desse item quando o custo é incorrido se os critérios de reconhecimento forem atendidos. Todavia, o valor contábil das peças que são substituídas devem ser baixado, independentemente de a parte substituída estar sendo depreciada separadamente ou não. E por fins de praticidade, se a apuração desse valor contábil não for praticável para a entidade, esta pode utilizar o custo de substituição como indicador do custo da parcela substituída na época em que foi adquirida ou construída. Ou seja, neste caso se acaba por se considerar para fins de praticidade o custo da nova peça reposta, como o valor a ser baixado para o resultado da entidade. Todavia, isto por si só, não significa que a peça em substituição não seja considerada um ativo imobilizado, pois a baixa se refere à peça antiga ou defeituosa e não a peça nova que passará a agregar valor ao ativo imobilizado original. Desta forma, nestes casos é evidente que estas peças utilizadas na substituição em intervalos regulares (por exemplo, um forno que requer novo revestimento após um número específico de horas de uso) aumentam a vida útil do ativo imobilizado principal e são consideradas no valor do ativo imobilizado e por isto devem proporcionar o direito ao crédito do ICMS, em respeito à sua própria natureza contábil.

\section{Reconhecimento e Mensuracão do Ativo Imobilizado - Prazo para o}

Creditamento do ICMS do Ativo Imobilizado: A interpretação do tema é polêmica, mas de qualquer forma, nos inclinamos a entender que o que o legislador tributário do ICMS fez, foi simplesmente ultra simplificar o tratamento tributário conferido ao ativo imobilizado, no que diz respeito à vida útil do bem. Enquanto outros tributos indiretos adotaram o creditamento com base no período de depreciação (ainda que o conceito de depreciação contábil tenha sido modificado por um conceito de depreciação fiscal - no IRPJ e no PIS-COFINS), noto que no ICMS, simplesmente o legislador tributário adotou uma depreciação presumida de 48 meses (ou seja, de 4 anos). Dessa forma, o legislador tributário simplificou a questão do creditamento do ICMS, considerando que todos os bens do ativo imobilizado serão utilizados em 4 anos. O problema surge, quando um bem do ativo imobilizado (que seja usado para fins de industrialização/comercialização de bens e 
serviços tributáveis pelo ICMS) tem uma vida útil econômica maior que 1 ano, mas menor do que os 48 meses. Em nosso entender, desde que tal bem do ativo imobilizado seja de fato utilizado na atividade de produção ou comercialização de bens e serviços tributáveis pelo ICMS, haveria naturalmente o direito ao crédito integral do ICMS pago na aquisição de bem do ativo imobilizado. A perda dos créditos remanescentes não nos figura uma medida adequada, pois só há a interrupção do creditamento nos casos em que há uma alienação do ativo imobilizado, que ainda poderá ser utilizado por um outro adquirente e fruir benefícios para outrem. No caso específico em que o bem exaure toda a sua funcionalidade num prazo menor que 48 meses, só vem a denotar que o referido bem do ativo imobilizado foi plenamente utilizado nas atividades atinentes àquele contribuinte, e por isto, entenderia que haveria o direito ao creditamento das parcelas remanescentes. Há inclusive aqueles que entendem que o creditamento total poderia ser feito em tempo menor que os 48 meses. Não me filio a esta ideia, por entender que a legislação tributária foi clara da necessidade de aproveitamento do crédito em parcelas de 48 avos, mas entendo que tendo o bem se exaurido na produção/comercialização de mercadorias e serviços tributados pelo ICMS haveria o direito do término do creditamento em relação às parcelas remanescentes.

52. Reconhecimento e Mensuracão do Ativo Imobilizado - Início do Creditamento do ICMS do Ativo Imobilizado: Em nosso ver, a interpretação conferida pelo fisco paulista é a mais adequada do ponto de vista de uma interpretação verdadeiramente teleológica e de acordo com o princípio da não-cumulatividade. Em que pese, a eventual possibilidade da legislação tributária em alterar algumas características dos institutos de direito privado apenas para fins dos seus efeitos tributários (e não para fins do direito privado), fato é que o crédito do ICMS está condicionado ao reconhecimento do bem como ativo imobilizado, este regido pelas normas jurídicocontábeis. Na medida em que as normas contábeis vigentes reconhecem que a vida útil do ativo imobilizado (que coincide com o momento de início de sua depreciação contábil) só se inicia quando este equipamento estiver efetivamente disponível para uso (quando está no local e em condição de funcionamento na forma pretendida pela empresa de modo a produzir e efetivamente poder gerar um fluxo de caixa para a entidade empresarial) o direito tributário não pode ignorar esta norma, pois ao se remeter a um conceito disciplinado na seara das normas contábeis e societárias deve incorporá-lo assim como definido pelo direito privado. Desta forma, entendo que a norma conforme do inciso I $\S 5^{\circ}$ do artigo 20 da Lei Kandir deve ser interpretada no sentido de que o crédito do ativo 
imobilizado deve se iniciar "no mês em que ocorrer a entrada no estabelecimento" de um ativo imobilizado, que esteja no local e pronto para uso nas finalidades empresariais. Portanto, há de se elogiar a lucidez das interpretações proferidas pelo Fisco paulista neste sentido, pois a interpretação literal conduziria a uma afronta ao princípio da nãocumulatividade e promoveria um verdadeiro desincentivo ao investimento industrial, em um Estado que é o coração econômico do Brasil.

\section{Reconhecimento e Mensuracão do Ativo Imobilizado - Bens (Ativo} Imobilizado) em poder de terceiros e o creditamento do ICMS: Em nosso ver, um aspecto relevante para se analisar cada um destes casos, é verificar com base na norma contábil, quem é o efetivo proprietário econômico daquele bem, e quem poderá reconhecer aquele ativo imobilizado como seu em seu balanço patrimonial. Ou seja, em cada caso específico deve ser avaliado os critérios contábeis estipulados no item 6 do Pronunciamento Contábil CPC $n^{\circ} 27$, cabendo verificar qual empresa possui de maneira efetiva a propriedade econômica representada pelos benefícios, riscos e controle desses bens. Isto porque a legislação tributária do ICMS ao tratar do ativo imobilizado fica sujeita ao regramento contábil vigente, de modo que só se pode conferir o crédito do ICMS, àquele contribuinte que possa de acordo com as normas jurídico-contábeis (notadamente do Pronunciamento CPC $\mathrm{n}^{\circ}$ 27) reconhecer este ativo imobilizado em seu balanço patrimonial.

\section{Reconhecimento e Mensuracão do Ativo Imobilizado - Crédito de Ativo}

Imobilizado para construcão de um bem imóvel: Nesta seara já nos anotava o Professor Alcides Jorge Costa ${ }^{510}$ que teoricamente o imposto sobre o valor acrescido abrangeria bens (coisas móveis corpóreas) e serviços, sendo que "os imóveis não seriam objeto apropriado para a incidência, pois não são consumidos", mas que, todavia, excepcionalmente, é possível que um determinado imposto sobre o valor acrescido atinja também a tributação dos imóveis. Uma das justificativas para esta eventual opção legislativa (da incidência do imposto sobre valor acrescido sobre os imóveis) seria, por exemplo, permitir que uma empresa adquirente de uma construção industrial possa se creditar do imposto sobre o valor da construção, evitando-se assim que este imposto onere o preço dos produtos que a empresa fabrica. Todavia, esta certamente não foi a opção legislativa adotada pelo legislador constitucional brasileiro, que excluiu do campo de tributação do nosso ICMS (brasileiro) os bens imóveis. Como destacado na parte teórica do capítulo três, os bens

${ }^{510}$ COSTA, Alcides Jorge. ICM na Constituição e na lei complementar. São Paulo: Ed. Resenha Tributária, 1979, p. 31. 
imóveis, de acordo com o artigo 155, I e artigo 156, II da CF/88 ${ }^{511}$, são tributados pelos Estados e pelos Municípios por meio de dois outros impostos: o imposto sobre transmissão causa mortis e doação, de quaisquer bens ou direitos (ITCMD) - de competência estadual nas transmissões não onerosas de bens imóveis; e o imposto sobre transmissão "inter vivos", a qualquer título, por ato oneroso, de bens imóveis (ITBI) - de competência municipal nas transmissões onerosas de bens imóveis. Desta forma os imóveis possuem no direito tributário brasileiro uma sistemática de tributação que está alheia à sistemática do imposto sobre o valor agregado, não sendo por isto possível a compensação destes outros impostos (ITCMD e ITBI) com o ICMS; de modo que, por exemplo, se uma empresa adquirir um imóvel industrial (um galpão industrial) sujeito à incidência do ITBI, não terá a possibilidade de compensar este tributo com o ICMS devido pela saída de mercadorias deste estabelecimento. Em outros sistemas tributários nos quais a tributação dos imóveis esteja albergada pelo campo de tributação do imposto sobre o valor agregado esta compensação tributária do imposto poderá ser possível pela regra da não-cumulatividade.

\section{Casos limítrofes de Bens Imóveis que são máquinas/equipamentos}

industriais: diante destes casos concretos, entendemos que a legislação tributária paulista parece deixar uma lacuna quando a construção civil é parte intrínseca do equipamento. Nestes casos limítrofes, entendemos que o aspecto técnico-contábil deva prevalecer, ou seja, deve ser questionado se o resultado da obra tem a substância de um imóvel ou de um equipamento, isto é, a sua efetiva utilização. Neste caso, é flagrante tratar-se de um equipamento industrial, embora fisicamente o mesmo esteja atrelado ao imóvel. Por fim, os argumentos constantes da Decisão Normativa CAT 2/2000 padecem de certa fragilidade e superficialidade, quando empregam o termo "mercadoria" para desqualificar a obra de construção civil, como passível de direito ao crédito do ICMS, pois a rigor nenhum ativo imobilizado seria mercadoria. O que a Lei Complementar 87/1996 prevê, em nosso entendimento, é o estado de "mercadoria" no momento da entrada no estabelecimento. Por outro lado, quando o resultado da construção civil possuir substância de imóvel, utilização

511 “Constituição Federal /1988:

Art. 155. Compete aos Estados e ao Distrito Federal instituir impostos sobre: (Redação dada pela Emenda Constitucional $n^{\circ}$ 3, de 1993)

I - transmissão causa mortis e doacão, de quaisquer bens ou direitos; (Redação dada pela Emenda Constitucional $n^{\circ}$ 3, de 1993)

(...)

Art. 156. Compete aos Municípios instituir impostos sobre:

(...)

II - transmissão "inter vivos", a qualquer título, por ato oneroso, de bens imóveis, por natureza ou acessão física, e de direitos reais sobre imóveis, exceto os de garantia, bem como cessão de direitos a sua aquisição;", 
própria de imóvel, não deve haver direito ao crédito do material utilizado para construí-lo. Por seu turno, ainda que seja um imóvel, caso o bem seja efetivamente utilizado como máquina/equipamento industrial gerando fluxo de caixas futuros e participando diretamente na produção/industrialização de mercadorias tributáveis pelo ICMS, dever-seia reconhecer o direito ao crédito a este ativo imobilizado, bem como aos componentes utilizados na montagem deste equipamento industrial.

56. Reconhecimento e Mensuração do Ativo Imobilizado e de Receitas de Vendas de mercadorias - Descaracterizacão de contratos como Locacão, Aluguel, Comodato e Figuras Análogas: Existe a possibilidade de descaracterização destes contratos de locação de bens, conforme preceitua a Decisão Normativa CAT 03/2000, identificando a situação de cessão definitiva do bem. Nestes casos, há que se observar a essência econômica das operações sobre os seus aspectos formais jurídicos. Em tese, não incide ICMS sobre operações de locação ou comodato. Todavia, deve o fisco paulista atentar para o eventual "abuso destas formas jurídicas”, pois muitas vezes haverá a cessão definitiva do bem ao suposto locatário, descaracterizando o contrato, o que enseja a tributação da operação pelo ICMS. Um detalhe importante a ser observado pelo Auditor Fiscal durante a execução de auditoria é verificar se, daquela suposta operação de cessão provisória do bem, os riscos e benefícios inerentes a sua posse foram definitivamente transferidos ao seu detentor; este fato caracterizaria a venda, portanto sujeita à incidência do ICMS. É importante destacar que, segundo o Pronunciamento $\mathrm{CPC} \mathrm{n}^{\circ} 30$, a receita deve ser reconhecida quando for provável que os benefícios econômicos associados à transação fluirão para a entidade transferidora do bem. Em alguns casos específicos, este aspecto somente poderá ser determinado quando do recebimento do pagamento ou quando, de alguma forma, a incerteza for removida. 


\section{REFERÊNCIAS BIBLIOGRÁFICAS}

ABE, Cesar Henrique S. "Disponibilidade Econômica da Renda", in Direito Tributário Atual, vol. 21, 2007, p. 191-200.

ATALIBA, Geraldo. Hipótese de incidência Tributária, São Paulo, Revista dos Tribunais, 1973.

ATALIBA, Geraldo. ICMS: competência impositiva na Constituição de 1988, Revista de Direito Administrativo, ${ }^{\circ}$ 195, Rio de Janeiro: jan/mar/1994.

ALMEIDA, Fábio da Silva e. Tributos e as Obrigações Acessórias. In: OLIVEIRA, Fábio Rodrigues de; GALLO, Mauro Fernando (Coords.). SPED e Sistemas de Informação. São Paulo: Fiscosoft Editora, 2013. p. 55-74.

AMARAL, Antonio Carlos Rodrigues do. Imposto sobre o Valor Agregado - IVA. São Paulo, Rumo: 1995.

AMARO, Luciano. Direito Tributário Brasileiro, 13a Ed, São Paulo: Editora Saraiva, 2007

ÁVILA, Humberto. Teoria dos Princípios - da definição à aplicação dos princípios jurídicos, $1^{\text {a }}$ Ed, São Paulo: Malheiros, 2008.

ÁVILA, Humberto. ICMS: Substituição tributária no Estado de São Paulo; base de cálculo; pauta fiscal; competência legislativa estadual para devolver a diferença constante entre o preço usualmente praticado e o preço constante na pauta; exame de constitucionalidade. Revista Dialética de Direito Tributário, São Paulo, no 124, p. 92-111, janeiro/2006.

BALL, Ray. International Financial Reporting Standards (IFRS): pros and cons for investors. Accounting and Business Research, International Accounting Policy Forum, 2006, p. 5-27.

BALEEIRO, Aliomar. Direito Tributário Brasileiro. $11^{\mathrm{a}}$ Ed., Rio de Janeiro: Editora Forense, 1999.

BALEEIRO, Aliomar. Uma Introdução à Ciência das Finanças. $16^{\mathrm{a}}$ ed. Rio de Janeiro/RJ: Forense, $17^{\mathrm{a}} \mathrm{Ed} ., 2010$.

BARROS, José Eduardo Monteiro. Interpretação Econômica em Direito Tributário. In: DE MORAES, Bernardo Ribeiro. Intepretação no Direito Tributário, São Paulo; Editora da Universidade Católica, 1975.

BECKER, Alfredo Augusto. Teoria Geral do Direito Tributário. São Paulo - Saraiva, 1966. 
BERGAMINI, Adolpho. ICMS - Coleção Curso de Tributos Indiretos Volume I, $2^{\mathrm{a}}$ Edição, São Paulo: FISCOSoft Editora, 2013.

BERTOLUCCI, Aldo Vincenzo. O Custo de Administração dos Tributos Federais no Brasil: comparações internacionais e propostas para aperfeiçoamento. 2005. Tese (Doutorado em Ciências Contábeis) - Faculdade de Economia, Administração e Contabilidade da Universidade de São Paulo - USP/SP, São Paulo, 2005.

BIAVA JÚNIOR, Roberto. Substituição Tributária e Antecipação no ICMS. 2013. 513 f. Dissertação (Mestrado em Direito Econômico, Financeiro e Tributário) - Faculdade de Direito, Universidade de São Paulo, São Paulo, 2013.

BONILHA, Paulo Celso Bergstrom. IPI e ICM Fundamentos da Técnica Não-Cumulativa. São Paulo: Editora Resenha Tributária Ltda., 1979.

BORGES, José Souto Maior. O imposto sobre o valor acrescido, in SCHOUERI, Luís Eduardo. Direito tributário- homenagem a Paulo de Barros Carvalho. São Paulo: Quartier Latin, p. 343-350, 2009.

BULHÕES PEDREIRA, José Luiz. Imposto sobre a Renda - Pessoas Jurídicas, vol. 1, Rio de Janeiro: Justec. 1979.

BRANDÃO MACHADO. "Breve Exame Crítico do art. 43 do CTN". in MARTINS, Ives G. S. (coord.). Estudos sobre o Imposto de Renda (em memória de Henry Tilbery). S. Paulo: Resenha Tributária. 1994.

BRASIL. Ministério da Fazenda. Secretaria do Tesouro Nacional. Receitas públicas: manual de procedimentos. Brasília: STN/Coordenação-Geral de Contabilidade, 2007.

BRASIL, Receita Federal do Brasil. PROJETO SPED: Disponível em <http://sped.rfb.gov.br/>, acessado em 01/01/2017.

CANTO, Gilberto Ulhoa. "A Aquisição de Disponibilidade e o Acréscimo Patrimonial no Imposto sobre a Renda". MARTINS, Ives G. S. (coord.). Estudos sobre o Imposto de Renda (em memória de Henry Tilbery). S. Paulo: Resenha Tributária, 1994.

CARVALHO, Nelson; CARMO, Carlos Henrique Silva do. Reconhecimento Contábil de Receitas: o que vem (ou pode vir) por aí. In: Roberto Quiroga Mosquera; Alexsandro Broedel Lopes. (Org.). Controvérsias jurídico-contábeis (aproximações e distanciamentos). $1^{\mathrm{a}}$ ed. São Paulo: Dialética, 2012.

CARVAlHO, Paulo de Barros. Curso de Direito Tributário. 16 ${ }^{\mathrm{a}}$ Ed., São Paulo: Ed. Saraiva, 2004.

CARVALHO, Paulo de Barros. Regra Matriz do ICM, Tese apresentada para a obtenção do Título de Livre Docente da Faculdade de Direito da PUC/SP, São Paulo, 1981. 
CARVALHO, Paulo de Barros. O absurdo da interpretação econômica do fato gerador Direito e sua autonomia - O paradoxo da interdisciplinaridade. Revista de Direito Tributário, São Paulo, no 97, p. 7-17, 2007.

CALIJURI, Monica S. S. As Novas Normas de Convergência Contábeis e seus reflexos para os contribuintes. In: Roberto Quiroga Mosquera; Alexsandro Broedel Lopes. (Org.). Controvérsias jurídico-contábeis (aproximações e distanciamentos). São Paulo: Dialética, 2011, v. 2.

CARRAZZA, Roque Antonio. ICMS, 9ª Ed., São Paulo: Malheiros, 2002.

COASE, Ronald. The firm, the market and the law. Chicago: The University of Chicago Press, 1988

COÊLHO, Sacha Calmon Navarro. Teoria Geral do Tributo, da Interpretação e da Exoneração Tributária, $2^{a}$ ed., São Paulo: Ed. Dialética, 2003.

COMPARATO, Fábio Konder. Ensaios e Pareceres de Direito Empresarial. Rio de Janeiro, Ed. Forense, 1977.

COSTA, Alcides Jorge. "Conceito de Renda Tributável” in MARTINS, Ives G. S. (coord.). Estudos sobre o Imposto de Renda (em memória de Henry Tilbery). São Paulo: Resenha Tributária, 1994.

COSTA, Alcides Jorge. Estudos sobre IPI, ICMS e ISS. 1ª ed. São Paulo: Dialética, 2009.

COSTA, Alcides Jorge. ICM na Constituição e na lei complementar. São Paulo: Ed. Resenha Tributária, 1979.

COSTA, Alcides Jorge. ICMS e Substituição Tributária. Revista Dialética de Direito Tributário, São Paulo, no 2, p. 70-95, novembro/1995.

DEMO, Pedro. Metodologia do conhecimento científico. São Paulo: Atlas, 2000.

DERZI, Misabel Abreu Machado. Distorções do Princípio da Não-Cumulatividade no ICMS - Comparação com o IVA Europeu, in Temas de Direito Tributário, I Congresso Nacional da Associação Brasileira de Direito Tributário, Belo Horizonte, Livraria Del Rey, p. 107-151, 1998.

DUARTE, Roberto Dias. O Brasil na era do conhecimento: Big Brother Fiscal. $3^{\text {a }}$ Ed., São Paulo: ideas@work, 2009.

DUARTE, Roberto Dias. SPED e as Pequenas Empresas. In: OLIVEIRA, Fábio Rodrigues de; GALLO, Mauro Fernando (Coords.). SPED e Sistemas de Informação. São Paulo: Fiscosoft Editora, 2013. p. 89-114.

FALCÃO, Amílcar de Araújo. Fato gerador da obrigação tributária. $6^{\mathrm{a}}$ ed. Rio de Janeiro: Forense, 1999. 
FASB - Financial Account Standards Board . Disponível em: http://www.fasb.org/isp/FASB/Page/SectionPage\&cid=1176156245663. Acesso em 01 jan. 2017.

FARIA, A. C.; FINATElli, J. R; GERON, C. M. S.; ROMEIRO, M. D. C. SPEDSistema Público de Escrituração Digital: Percepção dos contribuintes em relação os impactos da adoção do SPED In: $10^{\circ}$ Congresso USP de Controladoria e Contabilidade. Julho, 2010. Disponível em $\quad$ http://wwwcongressousp.fipecafi.org/webJa1tigos10201W248.pdf>, acessado em 01/01/2017.

FERNANDES, Andressa G. Torquato. Reforma tributária viável - Obrigações acessórias e SPED: Problemas e soluções para uma efetiva simplificação das obrigações tributárias acessórias. FISCOSoft Impresso, Artigo Federal, 2011.

FERNANDES, Edison Carlos. Nascimento, Vida e Morte do Regime Tributário de Transição - RTT. In: Roberto Quiroga Mosquera; Alexsandro Broedel Lopes. (Org.). Controvérsias jurídico-contábeis (aproximações e distanciamentos). $1^{\mathrm{a}}$ ed. São Paulo: Dialética, 2012, v. 3, p. 129-139.

FERNANDES, Marcelo Luiz Alves. Avaliação da utilização de documentos fiscais eletrônicos na rastreabilidade de cargas. Dissertação (mestrado) - Escola Politécnica da Universidade de São Paulo - USP, São Paulo, 2012.

FERRAZ, Roberto. O consumo, a concorrência, o mercado e as distorções da substituição tributária (para frente). Grandes questões atuais do Direito Tributário. v. 11. Valdir de Oliveira Rocha (coord). São Paulo: Dialética, p. 359-379, 2007.

FERRAZ JÚNIOR, Tércio Sampaio. Guerra Fiscal, Fomento e incentivo na Constituição Federal. Direito Tributário: Estudos em homenagem a Brandão Machado. Luís Eduardo Schoueri e Fernando Aurélio Zilvetti (coords.). SP: Dialética, p. 275-285, 1998.

FONSECA, Fernando Daniel de Moura. Normas Tributárias e a convergência das regras contábeis internacionais. 2013. Dissertação (Mestrado em Direito Econômico e Financeiro) - Faculdade de Direito, Universidade de São Paulo. São Paulo, 2013.

FORMIGONI, Henrique. A influência dos incentivos fiscais sobre a estrutura de capital e a rentabilidade das companhias abertas brasileiras não-financeiras. Tese (doutorado) Faculdade de Economia, Administração e Contabilidade da Universidade de São Paulo USP, São Paulo, 2008.

GRECCO, Gerson Begas. Proposta para mitigação do risco fiscal das organizações contábeis Brasileiras, 2014. Dissertação (Mestrado em Controladoria Empresarial), Universidade Presbiteriana Mackenzie, São Paulo, 2014.

GIAMBIASI, Fábio. ALÉM, Ana Cláudia. Finanças Pública - teoria e prática no Brasil. $4^{\text {a }}$ Ed., Rio de Janeiro: Elsevier, 2011

HALDEWANG, Chistian V. Gobernanza sistêmica y desarollo em América Latina. In: Revista de la CEPAL, ${ }^{\circ}$ 85, p. 35-52, 2005. 
HENDRICKSEN, Eldo S.; VAN BREDA, Michael F. Teoria da Contabilidade. São Paulo: Atlas, 1999.

HENRIQUE, Manoel de Almeida. Livros contábeis - a escrituração contábil no atual cenário tributário. São Paulo, Ed. Trevisan, 2016.

IGNÁCIO, Sérgio da Silva. Avaliação da conexão entre as normas e práticas contábeis e fiscais no Brasil.2010. Dissertação (mestrado) - Faculdade de Economia, Administração e Contabilidade de Ribeirão Preto, Universidade de São Paulo. Ribeirão Preto, 2010, 120 p.

IUDICIBUS, Sérgio. Teoria da Contabilidade. São Paulo: Editora Atlas, 1980.

IUDÍCIBUS, Sérgio; MARTINS, Eliseu; GELBCKE, Ernesto \& SANTOS, Ariovaldo. Manual de Contabilidade Societária: Aplicável a todas as Sociedades de Acordo com as Normas Internacionais e do CPC. São Paulo: Editora Atlas, 2010.

IUDÍCIBUS, Sérgio de; MARTINS, Eliseu; LOPES, Alexsandro Broedel. Os vários enfoques da Contabilidade. In: Roberto Quiroga Mosquera; Alexsandro Broedel Lopes. (Org.). Controvérsias jurídico-contábeis (aproximações e distanciamentos). $1^{\mathrm{a}}$ ed. São Paulo: Dialética, 2012, v. 3, p. 348-354.

KOCHË, José C. Fundamentos de metodologia científica; teoria da ciência e prática da pesquisa. Petrópolis: Vozes, 1997.

JESUS, Letícia Myauti de. A relação entre contabilidade societária e tributária no Brasil após a adoção das normas internacionais de contabilidade.2015. Dissertação (mestrado) Faculdade de Economia, Administração e Contabilidade, Universidade de São Paulo. São Paulo, 2015.

LAMB, M.; NOBES, C.W.; ROBERTS, A.D. International variations in the connections between tax and financial reporting, Accounting and Bussinnes Research, Routledge. Taylor and Francis Group. London, v. 28, n 3, 1998.

LAMY, Marcelo. Metodologia da Pesquisa Jurídica (Técnicas de Investigação, Argumentação e Redação). Rio de Janeiro, Editora Elsevier, 2011.

LOBATO, Valter; BREYNER, Frederico. Regime jurídico tributário do contrato de trespasse. Revista Dialética de Direito Tributário, São Paulo, $\mathrm{n}^{\circ}$ 203, p. 133-145, agosto/2012.

LOPES, Alexsandro Broedel; Mosquera, Roberto Quiroga. O Direito contábil fundamentos conceituais, aspectos da experiência brasileira e implicações. In: Roberto Quiroga Mosquera; Alexsandro Broedel Lopes. (Org.). Controvérsias jurídico-contábeis (aproximações e distanciamentos). $1^{\text {a }}$ ed. São Paulo: Dialética, 2010, v. 1, p. 56-81.

LOPES, Alexsandro Broedel; MARTINS, Eliseu. Teoria da contabilidade: uma nova abordagem. $1^{\mathrm{a}}$ Ed. São Paulo: Atlas, 2005. 
LOPES, Alexsandro Broedel; MARTINS, Eliseu. Teoria da Contabilidade: uma nova abordagem. São Paulo: Editora Atlas, 2017.

LOPES, Alexsandro Broedel. A teoria dos contratos, governança corporativa e contabilidade. In: LOPES, A. Broedel; IUDÍCIBUS, Sérgio de (Coords.) Teoria Avançada da Contabilidade. São Paulo: Atlas, 2012.

MACHADO, Hugo de Brito. ICMS. A Substituição Tributária no ICMS e a questão do preço final. Revista Dialética de Direito Tributário, São Paulo, nº67, p. 57-72, abril/2001.

MACHADO, Hugo de Brito, Curso de Direito Tributário, $28^{\mathrm{a}}$ edição, revista, atualizada e ampliada. São Paulo: Malheiros, 2007.

MACHADO SEGUNDO, Hugo de Brito; MACHADO, Raquel Cavalcanti Ramos. Breves anotações sobre a incidência do PIS e da COFINS na importação. Revista Dialética de Direito Tributário. São Paulo. n.108. p.78-90. set. 2004.

MARSHALL, C. L. Medindo e Gerenciando Riscos Operacionais em Instituições Financeiras. Rio de Janeiro: Qualitymark, 2002.

MARCHI, Eduardo C. Silveira. Guia de Metodologia Jurídica (Teses, Monografias e Artigos). 2a Ed., São Paulo, Editora Saraiva, 2009.

MARTINS, Eliseu. Contabilidade de Custos. São Paulo: Atlas, 1996.

MARTINS, Natanael. A Figura da Primazia da Substância sobre a Forma em Contabilidade e em Direito Tributário. In: Roberto Quiroga Mosquera; Alexsandro Broedel Lopes. (Org.). Controvérsias jurídico-contábeis (aproximações e distanciamentos). $1^{\mathrm{a}}$ ed. São Paulo: Dialética, 2012, v. 3, p. 267-280.

MARICATO, Andréia F. R. Os impactos das mudanças dos deveres instrumentais com a informatização fiscal: constituição do crédito tributário; prescrição e decadência; e prova tributária. 2014. Tese (Doutorado em Direito Tributário) - Pontifícia Universidade Católica - PUC/SP, São Paulo, 2014.

MARIZ, Ricardo. Fundamentos do Imposto de Renda. São Paulo: Quartier Latin 2008.

MARTINS, Natanael. A Figura da Primazia da Substância sobre a Forma em Contabilidade e em Direito Tributário. In: Roberto Quiroga Mosquera; Alexsandro Broedel Lopes. (Org.). Controvérsias jurídico-contábeis (aproximações e distanciamentos). $1^{\mathrm{a}} \mathrm{ed}$. São Paulo: Dialética, 2012, v. 3, p. 267-271.

MATTOS, Aroldo Gomes de, ICMS - Comentários à Legislação Nacional, São Paulo: Ed. Dialética, 2006.

MEIRELLES, Hely Lopes. Direito Administrativo Brasileiro, São Paulo: Malheiros, 2007.

MELO, José Eduardo Soares de. ICMS - Teoria e prática. $8^{\text {a }}$ Ed. São Paulo: Dialética, 2005 . 
MELLO, Newton Oller de. Nota Fiscal Eletrônica: Consolidação de um novo paradigma na administração tributária brasileira. In: Direito Tributário, Linguagem e Método. São Paulo: Ed. Noeses, 2008, p. 741-772.

MELLO, Newton Oller de. Os documentos fiscais eletrônicos no Brasil e na América Latina e seus impactos na automação de processos e no intercâmbio eletrônico de informações na cadeia logística. Tese (doutorado) - Escola Politécnica da Universidade de São Paulo - USP, São Paulo, 2014.

MYOSHI, Roberto Kazuo. Riscos de conformidade tributária: um estudo de caso no Estado de São Paulo. Dissertação (mestrado) - Faculdade de Economia, Administração e Contabilidade da Universidade de São Paulo - USP, Ribeirão Preto.

MIYOSHI, R. K; NAKAO, S. H. Riscos de conformidade tributária: um estudo de caso no estado de São Paulo. Revista de Contabilidade e Organizações, 6(14), 46-76, 2012.

MOON, M. J.; NORRIS, D. Does managerial orientation matter? The adopting government and e-government at the municipal level. Information System Journal, 15, p. 43-60, 2005.

MUSGRAVE, Richard Abel; MUSGRAVE, Peggy B. Finanças Pública - teoria e prática. Rio de Janeiro, Campus, São Paulo - Edusp 1980.

NASCIMENTO, Luciano Alves. Os fatores que impactam na adoção e na implementação do SPED na avaliação dos gestores das empresas brasileiras. Dissertação (mestrado em Administração) - Universidade Estácio de Sá, Rio de Janeiro, 2013.

NEUBIG, T.; SANGHA, B. Tax Risk and strong Corporate Governance. The Tax Executive, Mar/Apr2004, vol. 56, Issue 2, pp. 114-119.

NOGUEIRA DE AGUIAR, Gisleise. Avaliação dos impactos às competências dos profissionais contábeis após o Projeto SPED. Dissertação (mestrado em ciências contábeis e financeiras) - Pontifícia Universidade Católica de São Paulo - PUC-SP, São Paulo, 2012.

NOBES, Christopher; PARKER, Robert. Comparative International Accounting, 11th, Ed. London, 2010.

NOBES, C., 2011, IFRS Practices and the Persistence of Accounting System Classification, Abacus 47 (3), 267-283.

NOVELLO, Guilherme Lautenschlaeger. Subvenções para Investimento a Nova Realidade Contábil. In: Roberto Quiroga Mosquera; Alexsandro Broedel Lopes. (Org.). Controvérsias jurídico-contábeis (aproximações e distanciamentos). $1^{\mathrm{a}}$ ed. São Paulo: Dialética, 2012, v. 3, p. 157-168.

NUNES, Renato. Tributação e Contabilidade: alguns apontamentos sobre as relações entre os sistemas jurídico e contábil. Tese (Doutorado em Direito) - Pontifícia Universidade Católica de São Paulo, 2012. 
OLIVEIRA, Fábio Rodrigues de; GALLO, Mauro Fernando (Coords.). SPED e Sistemas de Informação. São Paulo: Fiscosoft Editora, 2013.

OLIVEIRA, Júlio Machado de. ICMS e guerra fiscal: origem, destino, natureza e extinção do direito ao crédito, in SCHOUERI, Luís Eduardo. Direito tributário- homenagem a Paulo de Barros Carvalho. São Paulo: Quartier Latin, p. 917-932, 2009.

PÊGAS, Paulo Henrique Barbosa. Manual de Contabilidade Tributária - $7^{\mathrm{a}}$ Ed. Rio de Janeiro: Freitas Bastos, 2011.

PIROSKA Soos. The Origins of Taxation at source in England. Amsterdam: IBFD, 1997.

POLIZZELLI, Vitor Borges. Balanço Comercial e Balanço Fiscal: Relações entre o Direito Contábil e o Direito Tributário e o Modelo Adotado pelo Brasil, in Direito Tributário Atual, vol. 24, 2010, p. 584-608.

POLIZELLI, Victor Borges. O Princípio da Realização da Renda - Reconhecimento de Receitas e Despesas para fins do IRPJ. Série Doutrina Tributária, v. VII. São Paulo: IBDT / Quartier Latin, 2012.

POSNER, Richard. A. Economic Analysis of Law. New York: Aspen Publishers, 2007.

REALE, Miguel. Teoria Tridimensional do Direito, $5^{\text {a }}$ ed., São Paulo: Saraiva, 1994.

REIS, Luciano Gomes dos; GALLO, Mauro Fernando; PEREIRA, Carlos Alberto. Manual de contabilização de tributos e contribuições sociais. São Paulo: Atlas, 2012.

REZENDE, Amaury José. Avaliação do Impacto dos Incentivos Fiscais sobre o retorno e as políticas de investimento e financiamento das empresas. Tese (livre-docência) Faculdade de Economia, Administração e Contabilidade da Universidade de São Paulo USP, Ribeirão Preto, 2015.

REZENDE, Amaury; PEREIRA, Carlos Alberto; DE ALENCAR, Roberta Carvalho. Contabilidade Tributária: entendendo a lógica dos tributos e seus reflexos sobre os resultados das empresas. São Paulo: Atlas, 2010.

ROCHA, Sérgio André. Evolução do RTT e Perspectivas. In: Roberto Quiroga Mosquera; Alexsandro Broedel Lopes. (Org.). Controvérsias jurídico-contábeis (aproximações e distanciamentos). $1^{\text {a }}$ ed. São Paulo: Dialética, 2012, v. 3, p. 332-347.

ROSA, José Roberto. Substituição Tributária no ICMS. 2a edição. Itu: Ed. Ottoni, 2009.

ROTHMANN, Gerd Willi. Tributação, sonegação e livre concorrência. In Ferraz Roberto (coord.). Princípio e limites da tributação 2, São Paulo: Quartier Latin, 2009.

ROTHMANN, Gerd Willi. Inconstitucionalidade múltipla na tributação da importação de serviços - Réquiem ou catarse do sistema tributário nacional, 2010 (Tese de Livre Docência do Departamento de Direito Econômico, Financeiro e Tributário / Faculdade de Direito - USP), 2010. 
SANDFORD. C.; GODWIN M.; HARDWICK, P. Administrative and costs of taxation. Bath: Fiscal Publications, 1989.

SANTOS, Ariovaldo dos. Demonstração do Valor Adicionado - como elaborar e analisar a DVA. $2^{\text {a }}$ edição. São Paulo: Ed. Atlas, 2007.

SANTI, Eurico Marcos Diniz de. Tributo e classificação das espécies no sistema tributário brasileiro. Disponível em: http://www.fiscosoft.com.br/a/5qd0/tributo-e-classificacao-dasespecies-no-sistema-tributario-brasileiro-eurico-marcos-diniz-de-santi. Acesso em: 01 jan. 2017.

SAMPAIO DE LIMA, Edson. Pesquisa sobre a redução nos custos de conformidade tributária e os investimentos no Sistema Público de Escrituração Digital - SPED no Brasil. Dissertação (mestrado em Ciências Contábeis) -Pontifícia Universidade Católica de São Paulo - PUC-SP, São Paulo, 2013.

SANTOS, Ariovaldo dos. Ajuste a valor presente. In: Roberto Quiroga Mosquera; Alexsandro Broedel Lopes. (Org.). Controvérsias jurídico-contábeis (aproximações e distanciamentos). $1^{\text {a }}$ ed. São Paulo: Dialética, 2012, v. 3, p. 116-128.

SCAFF, Fernando Facury. Aspectos Financeiros do Sistema de Organização Territorial do Brasil, Revista Dialética de Direito Tributário, São Paulo, no 112, p. 29-30, janeiro/2005.

SCAFF, Fernando F.; SILVEIRA, Alexandre C. Competência tributária, transferências obrigatórias e incentivos fiscais. In CONTI, José Mauricio; SCAFF, Fernando F.; BRAGA, Carlos E. F. (orgs.). Federalismo Fiscal: questões contemporâneas. Florianópolis: Conceito Editorial - IBDF, 2010,

SCHOUERI, Luís Eduardo. Direito Tributário. $1^{\text {a }}$ Ed., São Paulo: Saraiva, 2011.

SCHOUERI, Luís Eduardo. "O Mito do Lucro Real na Passagem da Disponibilidade Jurídica para a Disponibilidade Econômica", in Mosquera, Roberto Q. e Lopes, Alexsandro B. (coord.) Controvérsias Jurídico-Contábeis (Aproximações $e$ Distanciamentos). São Paulo: Dialética. 2010, p. 241-264.

SCHOUERI, L. E. . Planejamento tributário e garantias dos contribuintes: entre a norma geral antielisão portuguesa e seus paralelos brasileiros. In: Daniel Freire e Almeida; Fabio Luiz Gomes; João Ricardo Catarino. (Org.). Garantias dos contribuintes no sistema tributário. $1^{\mathrm{a}}$ Ed. São Paulo, 2012.

SCHOUERI, Luís Eduardo. "Nova Contabilidade e Tributação: da Propriedade à Beneficial Ownership", in Mosquera, Roberto Q. e Lopes, Alexsandro B. (coord.) Controvérsias Jurídico-Contábeis (Aproximações e Distanciamentos), Vol. $5^{\circ}$, São Paulo: Dialética. 2014, 
SLAVOV, Thiago Nascimento Borges. Sistemas de Informação e Sistemas Integrados de Gestão. In: OLIVEIRA, Fábio Rodrigues de; GALLO, Mauro Fernando (Coords.). SPED $e$ Sistemas de Informação. São Paulo: Fiscosoft Editora, 2013. p. 27-53.

SOUZA. Rubens Gomes de. Compêndio de Legislação Tributária. $3^{\mathrm{a}}$ ed. São Paulo: Ed. Financeiras, 1960.

SUNDER, Shyam. Theory of acccounting and control. Cincinnnati: International Thomson Publishing, 1997.

THE WORLD BANK, IFC AND PWC, Paying Taxes 2013: The Global Picture, World Bank, International Finance Corporation and PricewaterhouseCoopers, www.doingbusiness.org, English Version, 2012.

TERSI, Vinicius Feliciano. A fixação da base de cálculo do IRPJ e da CSL a partir do padrão IFRS. 2016. Dissertação (Mestrado em Direito Econômico e Financeiro) Faculdade de Direito, Universidade de São Paulo. São Paulo, 2016.

TÔRRES, Heleno Taveira. Direito Tributário e Direito Privado. Autonomia privada, simulação e elusão tributária. São Paulo: Editora Revista dos Tribunais, 2003.

TÔRRES, Heleno Taveira. O IVA na Experiência Estrangeira e a Tributação das Exportações no Direito Brasileiro, in Revista Fórum de Direito Tributário - RFDT, Belo Horizonte, n. 16, p. 43-62, jul./ago. 2005.

TÔRRES, Heleno Taveira. Substituição Tributária - Regime Constitucional, Classificação e Relações Jurídicas (materiais e processuais). Revista Dialética de Direito Tributário, São Paulo, nº70, p. 87-108, julho/2001.

TORRES, Ricardo Lobo. O Princípio da Não-Cumulatividade e o IVA no Direito Comparado, in Princípio da Não-Cumulatividade. Coordenador Ives Gandra da Silva Martins. Revista dos Tribunais, São Paulo, p. 139-170, 2004.

TORRES, Ricardo Lobo. Normas de interpretação e integração no Direito Tributário, $3^{\mathrm{a}}$ Ed., Rio de Janeiro: Editora Renovar, 2000

VELlOSO, Andrei Pitten. Conceitos e Competências Tributárias. São Paulo: Editora Dialética, 2005.

VERGINELLI, Carolina Velloso. Projeto SPED. In: OLIVEIRA, Fábio Rodrigues de; GALLO, Mauro Fernando (Coords.). SPED e Sistemas de Informação. São Paulo: Fiscosoft Editora, 2013. p. 55-88.

ZILVETI, Fernando A. “O Princípio da Realização da Renda”. SCHOUERI, Luís E. (org.) Direito Tributário. Homenagem a Alcides Jorge Costa, vol. I. São Paulo: Quartier Latin, 2003. 


\section{APÊNDICE: Quadro de Riscos Fiscais ${ }^{512}$ dos Impactos Tributários da}

\section{Nova Contabilidade (padrão internacional) no ICMS..$^{513} 514$}

\begin{tabular}{|c|c|c|c|c|}
\hline$\underline{\mathbf{N}^{\mathbf{0}}}$ & Tema & $\begin{array}{l}\text { Normas Contábeis } \\
\underline{\text { (IFRS/CPC) }}\end{array}$ & $\begin{array}{l}\frac{\text { Dispositivo do }}{\text { RICMS/SP }} \\
\underline{\underline{y}}\end{array}$ & $\begin{array}{l}\text { Natureza do Risco } \\
\underline{\text { Fiscal }}\end{array}$ \\
\hline 1 & $\begin{array}{l}\frac{\text { Valor }}{\text { Realizá }} \\
\frac{\text { vel }}{\text { Líquido }} \\
\frac{\text { dos }}{\text { Estoqu }} \\
\underline{\text { es }} \\
\text { Ativos - } \\
\text { Estoque } \\
\text { de } \\
\text { mercad } \\
\text { oria } \\
\text { com } \\
\text { valor } \\
\text { menor } \\
\text { que o } \\
\text { custo } \\
\text { históric } \\
\text { o. }\end{array}$ & 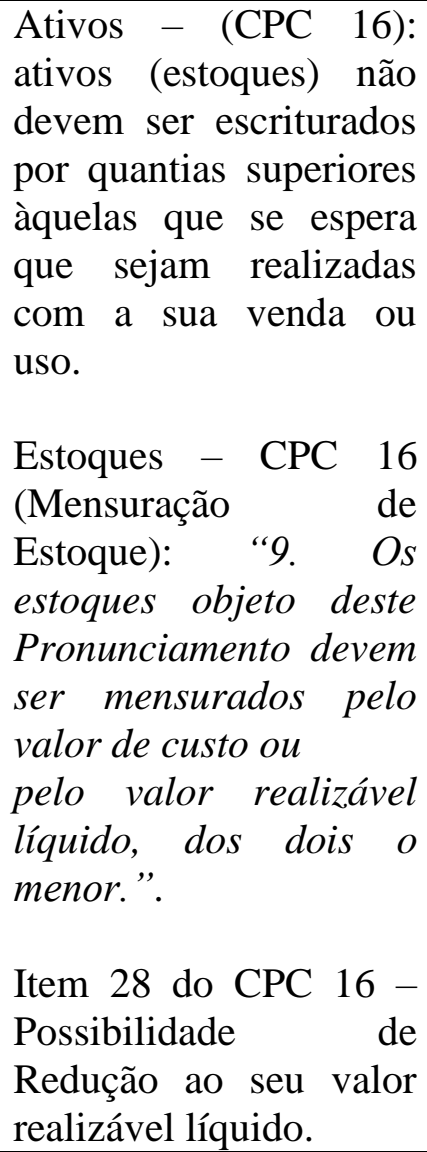 & $\begin{array}{l}\text { Art. } 37 \text { a } 39 \text { do RICMS } \\
\text { (base de cálculo ICMS) } \\
\text { e Artigo } 13 \text { da Lei } \\
\text { Kandir: existem vários } \\
\text { critérios para } \\
\text { determinação da base } \\
\text { de cálculo tais como: } \\
\text { Valor Operação, Preço } \\
\text { Corrente e FOB na falta } \\
\text { de valor operação, } \\
\text { Custo da mercadoria } \\
\text { nas Transferências. Há } \\
\text { situações subsidiárias } \\
\text { que permitem a } \\
\text { utilização do custo } \\
\text { contábil dos estoques, } \\
\text { principalmente em } \\
\text { situações em que não } \\
\text { há valor de mercado } \\
\text { praticado. }\end{array}$ & $\begin{array}{l}\text { Risco dos valores dos } \\
\text { Estoques em } \\
\text { transferências ou outras } \\
\text { operações que não } \\
\text { sejam compra e venda } \\
\text { (com valor efetivo de } \\
\text { mercado), estarem } \\
\text { "subavaliadas" } \\
\text { Contábil } \\
\text { aplicação do VRL - por } \\
\text { valores abaixo do custo } \\
\text { histórico daquela } \\
\text { mercadoria). Risco em } \\
\text { operações tais como: } \\
\text { transferência, } \\
\text { consignação, } \\
\text { bonificação } \\
\text { mercadorias, com } \\
\text { industrialização, etc., } \\
\text { sejam feitas pelos } \\
\text { valores contábeis após a } \\
\text { redução ao VRL (mais } \\
\text { baixos do que o custo } \\
\text { histórico). }\end{array}$ \\
\hline
\end{tabular}

\footnotetext{
${ }^{512} \mathrm{O}$ termo risco fiscal depende do ponto de vista. Aqui é exemplificada uma situação em que o novo padrão contábil poderia em tese favorecer a tributação para as empresas, mas em outras situações que serão vistas, o novo padrão contábil poderá resultar em um aumento da tributação do ICMS. O certo é que há insegurança jurídica sobre este tema e sobre vários aspectos técnicos que serão tratados neste capítulo, especialmente pelo fato de que o legislador tributário não legislou sobre a "neutralidade tributária" no ICMS e nem sequer analisou os possíveis impactos que a convergência contábil internacional poderia trazer para este tributo.

513 Adaptado do "Relatório Preambular sobre a Convergência Contábil Internacional e os seus Efeitos, Desafios e Oportunidades diante da Legislação Tributária Paulista”. Documento produzido internamente na Secretaria da Fazenda do Estado de São Paulo pelo Grupo de Trabalho PROFISCO 4.8 voltado à implantação do Sistema Público de Escrituração Digital (SPED) na Secretaria da Fazenda-SP.

$514 \mathrm{O}$ presente Grupo de Trabalho voltado à implantação do Sistema Público de Escrituração Digital (SPED) na Secretaria da Fazenda-SP atuou nas seguintes vertentes:

1.Escrituração Contábil Digital (ECD) e Escrituração Fiscal Digital EFD (para os contribuintes de ICMS e IPI);

2.Definição dos Novos Roteiros de Auditoria Fiscal e Contábil na Fiscalização do ICMS pela SEFAZ-SP;

3. Análise dos Impactos na Auditoria Fiscal dos novos critérios de reconhecimento, mensuração e evidenciação dos elementos contábeis e das operações das empresas trazidos pelas Normas Internacionais de Contabilidade.

4-Treinamento em Auditoria Contábil Tributária Digital de 1.800 Fiscais da SEFAZ-SP.
} 


\begin{tabular}{|c|c|c|c|c|}
\hline$\underline{\mathrm{N}^{\circ}}$ & Tema & $\begin{array}{l}\text { Normas Contábeis } \\
\text { (IFRS/CPC) }\end{array}$ & $\begin{array}{l}\text { Dispositivo do } \\
\underline{\text { RICMS/SP }}\end{array}$ & $\begin{array}{l}\text { Natureza do Risco } \\
\text { Fiscal }\end{array}$ \\
\hline 2 & $\begin{array}{l}\frac{\text { Base de }}{\text { cálculo }} \\
\underline{\text { na }} \\
\frac{\text { transfe }}{\text { rência }} \\
\frac{\text { de }}{\text { mercad }} \\
\underline{\text { oria }} \\
\text { para } \\
\text { outro } \\
\underline{\text { Estado. }}\end{array}$ & $\begin{array}{l}\text { Estoques - } \text { CPC } 16 \\
\text { (Mensuração } \\
\text { Estoque: } \\
\text { Histórico ou VRL, dos } \\
\text { dois o menor): } \\
\text { "9. Os estoques objeto } \\
\text { deste Pronunciamento } \\
\text { devem ser mensurados } \\
\text { pelo valor de custo ou } \\
\text { pelo valor realizável } \\
\text { líquido, dos dois o } \\
\text { menor.". }\end{array}$ & 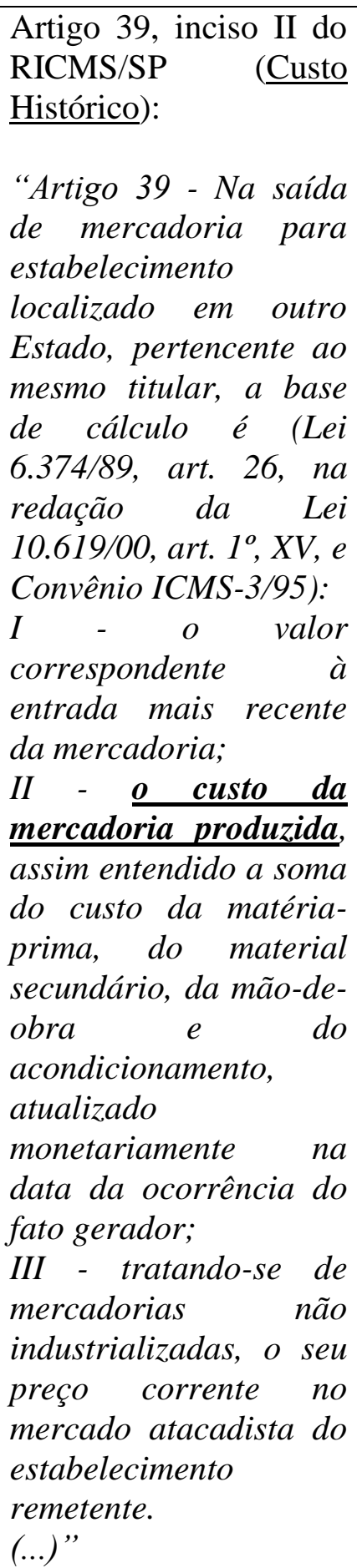 & $\begin{array}{l}\text { A definição dos fatores } \\
\text { de produção que } \\
\text { integram o CPV da } \\
\text { mercadoria (custo da } \\
\text { mercadoria produzida), } \\
\text { constante re } \\
\text { RICMS/SP, é bastante } \\
\text { imprecisa. De qualquer } \\
\text { forma, o Custo } \\
\text { Histórico é o critério } \\
\text { defendido pelo Fisco, } \\
\text { pois, numa Auditoria } \\
\text { Fiscal, é o critério que } \\
\text { proporciona } \\
\text { segurança maior } \\
\text { objetividade à ação } \\
\text { fiscal. O VRL trazido } \\
\text { pelo IFRS é um critério } \\
\text { de valoração de estoque } \\
\text { assaz subjetivo. } \\
\text { Todavia, temos o risco } \\
\text { de manipulação dos } \\
\text { valores } \\
\text { transferências tanto nas } \\
\text { Entradas de Outras UFs } \\
\text { como nas saídas } \\
\text { interestaduais. } \\
\text { adoção ora do VRL, ora } \\
\text { do Custo Histórico, } \\
\text { pode ensejar a } \\
\text { manipulação a nas } \\
\text { transferências } \\
\text { interestaduais } \\
\text { créditos do ICMS da } \\
\text { Guerra Fiscal. }\end{array}$ \\
\hline 3 & $\begin{array}{l}\text { Critéri } \\
\text { o de } \\
\text { Valoraç } \\
\text { ão dos } \\
\text { Estoqu } \\
\text { es } \\
\text { (PEPS }\end{array}$ & $\begin{array}{l}\text { Estoques - CPC } 25 \\
\text { (Critério de Valoração } \\
\text { do Estoque - PEPS ou } \\
\text { Custo Médio): } \\
\text { "25. O custo dos } \\
\begin{array}{lll}\text { estoques, que não } \\
\text { sejam os tratados nos }\end{array}\end{array}$ & $\begin{array}{l}\text { Artigo 39, I do } \\
\text { RICMS/SP: Critério } \\
\text { UEPS- Entrada Mais } \\
\text { Recente. } \\
\text { "Artigo } 39 \text { - Na saída } \\
\text { de mercadoria para } \\
\text { estabelecimento }\end{array}$ & $\begin{array}{l}\text { Num cenário } \\
\text { inflacionário, o risco é } \\
\text { ocorrer a } \\
\text { superavaliação da base } \\
\text { de transferência (maior } \\
\text { destaque de ICMS), } \\
\text { onerando } \\
\text { contribuinte. As IFRS }\end{array}$ \\
\hline
\end{tabular}




\begin{tabular}{|c|c|c|c|c|}
\hline$\underline{\mathbf{N}^{0}}$ & Tema & $\begin{array}{l}\text { Normas Contábeis } \\
\text { (IFRS/CPC) }\end{array}$ & $\begin{array}{l}\text { Dispositivo do } \\
\underline{\text { RICMS/SP }}\end{array}$ & $\begin{array}{l}\text { Natureza do Risco } \\
\text { Fiscal }\end{array}$ \\
\hline & $\begin{array}{l}\mathbf{x} \\
\text { UEPS) }\end{array}$ & $\begin{array}{l}\text { itens } 23 \text { e } 24, \text { deve ser } \\
\text { atribuído pelo uso do } \\
\text { critério Primeiro a a } \\
\text { Entrar, Primeiro a Sair } \\
\text { (PEPS) ou pelo critério } \\
\text { do custo r médio } \\
\text { ponderado. A entidade } \\
\text { deve usar o mesmo } \\
\text { critério de custeio para } \\
\text { todos os estoques que } \\
\text { tenham natureza e uso } \\
\text { semelhantes para a } \\
\text { entidade. Para os } \\
\text { estoques que tenham } \\
\text { outra } \\
\text { natureza ou uso, podem } \\
\text { justificar-se diferentes } \\
\text { critérios } \\
\text { valoração. }\end{array}$ & 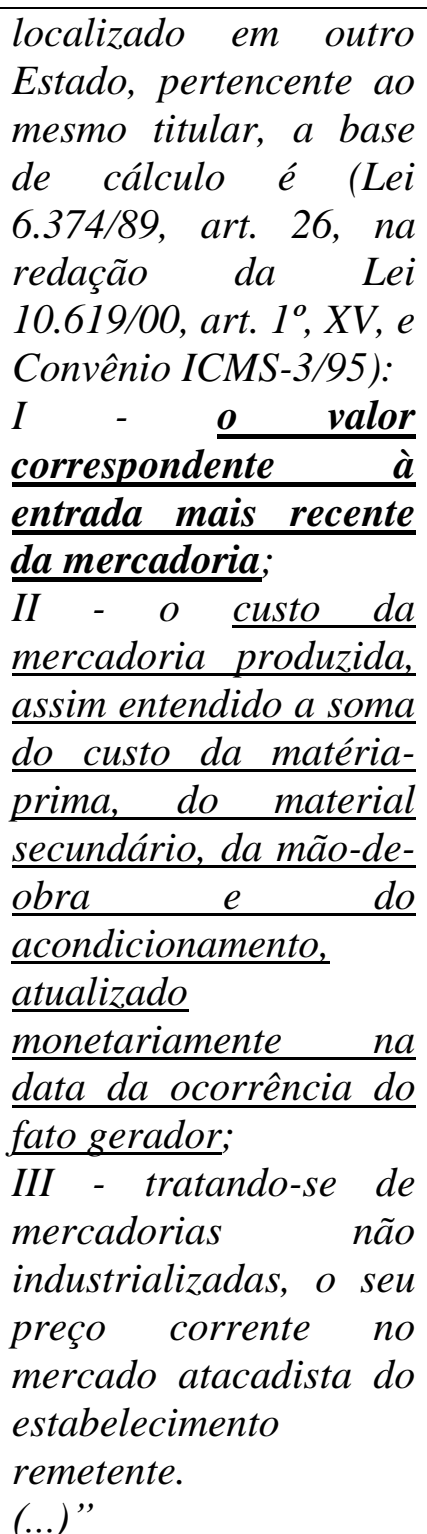 & $\begin{array}{lr}\text { sequer mencionam o } \\
\text { UEPS como critério de } \\
\text { valoração dos estoques, } \\
\text { o que pode acarretar } \\
\text { questionamentos } \\
\text { jurídicos. } \\
\text { Adicionalmente existe } \\
\text { o risco do contribuinte } \\
\text { se aproveitar desta } \\
\text { regra para trazer } \\
\text { mercadorias } \\
\text { transferências em } \\
\text { Estados com benefícios } \\
\text { fiscais por valores } \\
\text { superavaliados. }\end{array}$ \\
\hline 4 & $\begin{array}{l}\text { Itens de } \\
\text { Custo } \\
\text { que } \\
\text { devem } \\
\text { integra } \\
\text { r os } \\
\text { Estoqu } \\
\text { es } \\
\text { transfe } \\
\text { ridos. }\end{array}$ & 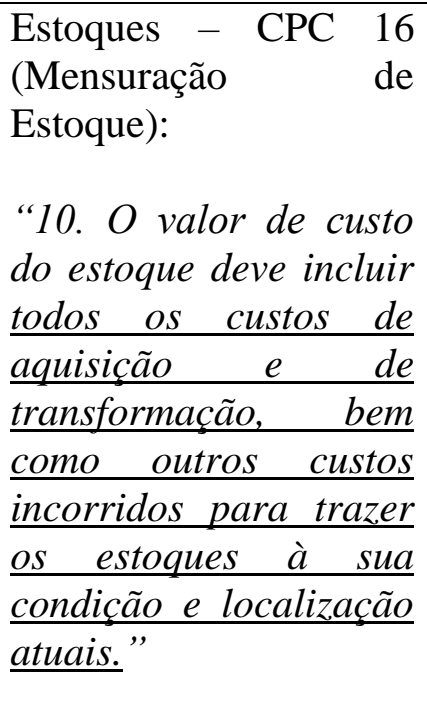 & $\begin{array}{l}\text { Artigo 39, II do } \\
\text { RICMS/SP: Critério } \\
\text { restrito de Custo da } \\
\text { Mercadoria Produzida. } \\
\text { "Artigo } 39 \text { - Na saída } \\
\text { de mercadoria para } \\
\text { estabelecimento } \\
\text { localizado em outro } \\
\text { Estado, pertencente ao } \\
\text { mesmo titular, a base } \\
\text { de cálculo é: } \\
\text { (...) } \\
\text { II - o custo da } \\
\text { mercadoria produzida, }\end{array}$ & $\begin{array}{l}\text { Falta de segurança } \\
\text { jurídica para o Fisco e } \\
\text { para o contribuinte de } \\
\text { quais itens compõe o } \\
\text { Custo da Mercadoria } \\
\text { para fins de } \\
\text { transferência, abrindo } \\
\text { possibilidade de } \\
\text { manipulação desta base } \\
\text { de cálculo. } \\
\text { Os itens mencionados } \\
\text { na legislação tributária } \\
\text { (matéria-prima, } \\
\text { material secundário, } \\
\text { mão-de-obra, }\end{array}$ \\
\hline
\end{tabular}




\begin{tabular}{|c|c|c|c|c|}
\hline$\underline{\mathbf{N}^{\mathbf{0}}}$ & Tema & $\begin{array}{l}\text { Normas Contábeis } \\
\text { (IFRS/CPC) }\end{array}$ & $\begin{array}{l}\text { Dispositivo do } \\
\underline{\text { RICMS/SP }}\end{array}$ & $\begin{array}{l}\text { Natureza do Risco } \\
\text { Fiscal }\end{array}$ \\
\hline & & & 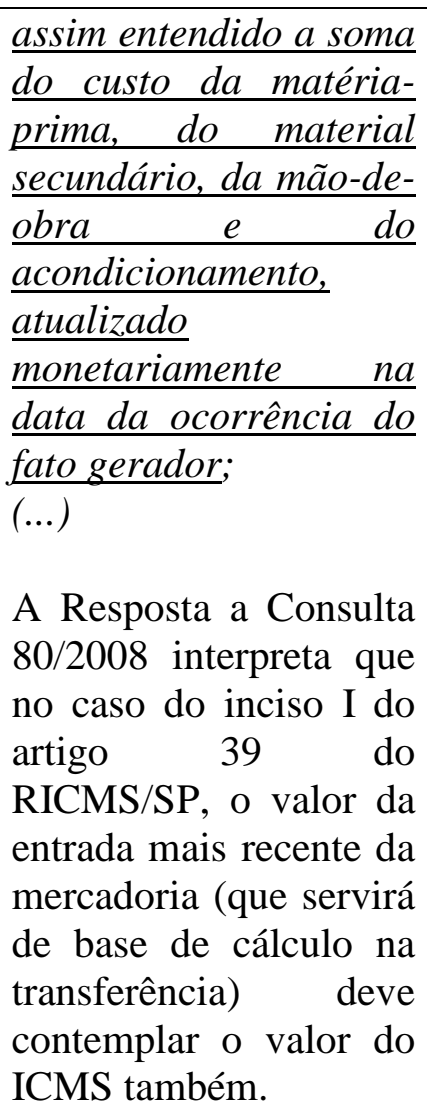 & $\begin{array}{l}\text { acondicionamento) são } \\
\text { exemplificativos? Ou } \\
\text { deve-se adotar como } \\
\text { Custo das Mercadorias } \\
\text { nas transferências o } \\
\text { conceito mais amplo da } \\
\text { norma da contabilidade } \\
\text { (CPC 16 item 10)? }\end{array}$ \\
\hline 5 & $\begin{array}{l}\text { Ajuste } \\
\text { a valor } \\
\text { present } \\
\text { e. }\end{array}$ & $\begin{array}{l}\text { A Lei 6404/76, na } \\
\text { redação da Lei } \\
11.638 / 07 \text {, requer o } \\
\text { ajuste a valor presente } \\
\text { nos realizáveis e } \\
\text { exigíveis a longo prazo } \\
\text { e, no caso de efeito } \\
\text { relevante, também nos } \\
\text { de curto prazo. } \\
\text { Receitas - CPC } 30 \text { - } \\
\text { Mensuração a Ajuste a } \\
\text { Valor Presente: } \\
\text { "8. Vendas para } \\
\text { recebimento parcelado } \\
\text { (em prestacóos). } \\
\text { A receita atribuível ao } \\
\text { preço de venda, líquido } \\
\text { de juros, é reconhecida } \\
\text { à data da venda. O } \\
\text { preço de venda é o } \\
\text { valor presente da }\end{array}$ & 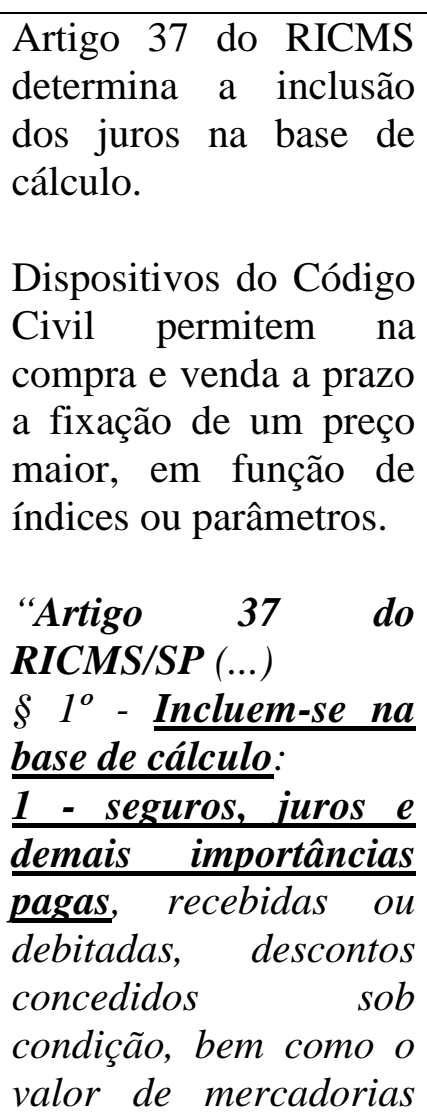 & $\begin{array}{l}\text { Quais são os impactos } \\
\text { do Ajuste a Valor } \\
\text { Presente das Receitas } \\
\text { de vendas de } \\
\text { Mercadoria (a prazo) } \\
\text { sobre à arrecadação do } \\
\text { ICMS? } \\
\text { risco está na } \\
\text { subavaliação da base de } \\
\text { cálculo do ICMS, } \\
\text { excluindo-se a parcela } \\
\text { contabilizada como } \\
\text { receita financeira. O } \\
\text { argumento contábil é } \\
\text { que a natureza } \\
\text { econômica da receita } \\
\text { deve ser preservada e } \\
\text { considerada quando da } \\
\text { tributação do ICMS. A } \\
\text { apuração do AVP } \\
\text { possui, inclusive, } \\
\text { sólido fundamento na }\end{array}$ \\
\hline
\end{tabular}




\begin{tabular}{|c|c|c|c|c|}
\hline$\underline{\mathrm{N}^{\circ}}$ & Tema & $\begin{array}{l}\text { Normas Contábeis } \\
\text { (IFRS/CPC) }\end{array}$ & $\frac{\text { Dispositivo do }}{\underline{\text { RICMS/SP }}}$ & $\begin{array}{l}\text { Natureza do Risco } \\
\text { Fiscal }\end{array}$ \\
\hline & & 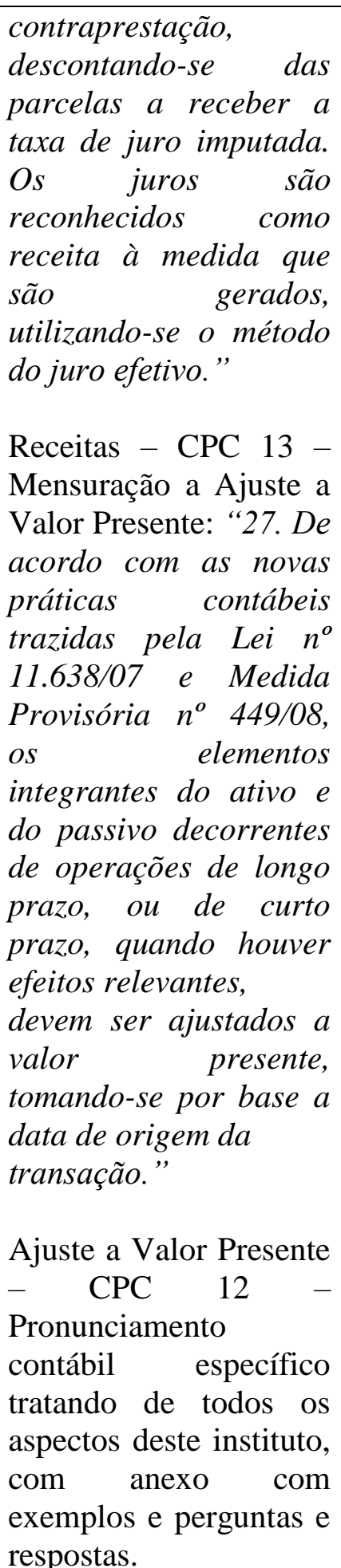 & 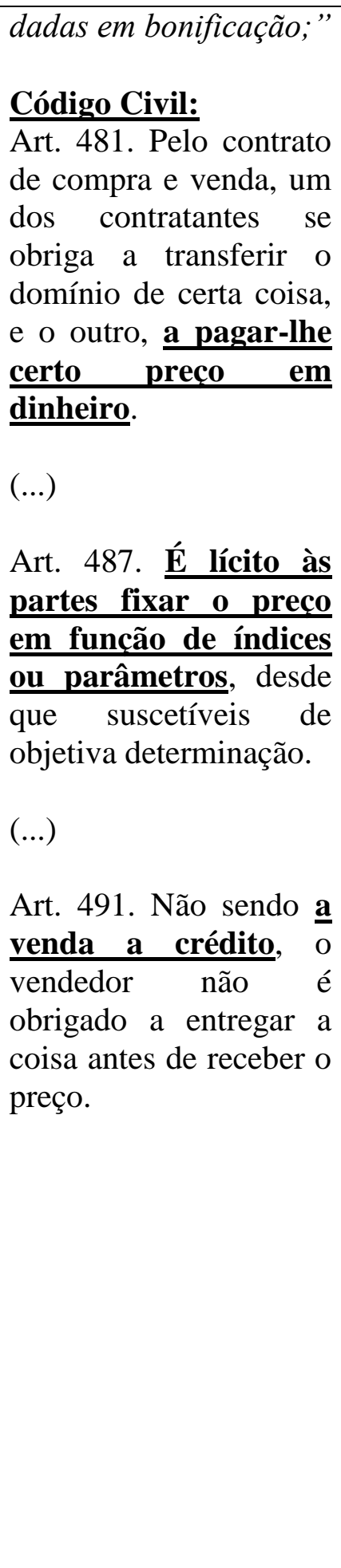 & $\begin{array}{l}\text { Lei 6.404/76 e suas } \\
\text { alterações. } \\
\text { Risco da Argumentação } \\
\text { Jurídica, Econômica e } \\
\text { Contábil de que os } \\
\text { Juros } \\
\text { Financeiras) não são } \\
\text { tributados pelo ICMS } \\
\text { (Estadual) e sim pelo } \\
\text { IOF (Federal). }\end{array}$ \\
\hline 6 & $\begin{array}{l}\text { Ativo } \\
\text { Imobili } \\
\text { zado } \\
\text { nas } \\
\text { Conces } \\
\text { sões: }\end{array}$ & $\begin{array}{l}\text { Interpretação } \text { ICPC } \\
\text { 01 - Concessões - que } \\
\text { dispõe } \\
\text { aspectos sobre } \\
\text { relativos aos contábeis } \\
\text { de concessões, sob a }\end{array}$ & 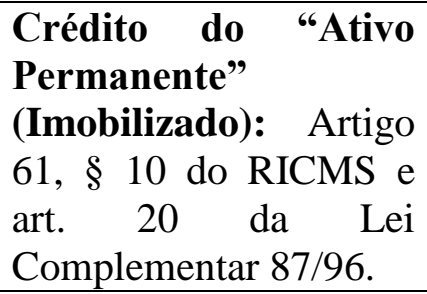 & $\begin{array}{l}\text { Poderá haver } \\
\text { discrepâncias } \\
\text { significativas entre as } \\
\text { duas sistemáticas de } \\
\text { reconhecimento (ativo } \\
\text { imobilizado versus }\end{array}$ \\
\hline
\end{tabular}




\begin{tabular}{|c|c|c|c|c|}
\hline$\underline{\mathbf{N}^{\circ}}$ & Tema & $\begin{array}{l}\text { Normas Contábeis } \\
\text { (IFRS/CPC) }\end{array}$ & $\frac{\text { Dispositivo do }}{\underline{\text { RICMS/SP }}}$ & $\begin{array}{l}\text { Natureza do Risco } \\
\underline{\text { Fiscal }}\end{array}$ \\
\hline & $\begin{array}{l}\text { novo } \\
\text { tratame } \\
\text { nto } \\
\text { contábil } \\
\text { (Ativo } \\
\text { Finance } \\
\text { iro ou } \\
\text { Intangív } \\
\text { el) }\end{array}$ & $\begin{array}{l}\text { ótica da entidade } \\
\text { concessionária, isto é }, \\
\text { aquela responsável por } \\
\text { operar a concessão. } \\
\text { Dentre as principais } \\
\text { alterações promovidas } \\
\text { pelo ICPC-01 está } \\
\text { aquela em que a } \\
\text { entidade concessionária } \\
\text { deixa de registrar a } \\
\text { infraestrutura recebida } \\
\text { como imobilizado ou } \\
\text { como ativo arrendado. } \\
\text { Por outro lado, o } \\
\text { operador reconhece um } \\
\text { ativo financeiro ou } \\
\text { intangível pela extensão } \\
\text { do direito contratual de } \\
\text { recebimento } \\
\text { dinheiro, outro ativo } \\
\text { financeiro ou um } \\
\text { intangível. }\end{array}$ & $\begin{array}{l}\text { A legislação tributária } \\
\text { não menciona a } \\
\text { possibilidade de crédito } \\
\text { do ICMS para } \\
\text { Financeiros } \\
\text { Intangíveis. }\end{array}$ & $\begin{array}{l}\text { ativo } \\
\text { financeiro/intangível). } \\
\text { A) Potencial perda dos } \\
\text { créditos de ICMS sobre } \\
\text { o ativo imobilizado haja } \\
\text { vista que } \\
\text { concessionária passará } \\
\text { a amortizar um ativo } \\
\text { financeiro. } \\
\text { exemplo, no caso da } \\
\text { construção de uma } \\
\text { subestação de energia } \\
\text { elétrica por uma } \\
\text { concessionária, que } \\
\text { pela } \\
\text { regulatória não deverá } \\
\text { figurar no Ativo } \\
\text { Imobilizado. }\end{array}$ \\
\hline 7 & $\begin{array}{l}\text { Arrend } \\
\text { amento } \\
\text { Mercan } \\
\text { til } \\
\text { Operac } \\
\text { ional }\end{array}$ & $\begin{array}{l}\text { Leasing Operacional - } \\
\text { CPC 06: Arrendamento } \\
\text { mercantil é classificado } \\
\text { como operacional se ele } \\
\text { não transferir } \\
\text { substancialmente todos } \\
\text { os risos e benefícios } \\
\text { inerentes à propriedade. } \\
\text { Neste caso, o Ativo é } \\
\text { reconhecido somente } \\
\text { no Arrendador (e não } \\
\text { na Arrendatária). } \\
\text { Itens } 8,33 \text { e } 49 \text { do CPC } \\
06 . \\
\text { De acordo com o CPC } \\
06, \quad \text { o arrendamento } \\
\text { mercantil é classificado } \\
\text { como operacional se ele } \\
\text { não substancialmente todos } \\
\text { suber } \\
\text { os risos e benefícios } \\
\text { inerentes à propriedade. } \\
\text { Sob o ponto de vista do }\end{array}$ & $\begin{array}{l}\text { Confere o Direito do } \\
\text { Crédito á } \\
\text { Arrendatário do Bem } \\
\text { em Leasing (Art. 63, } \\
\text { III, } \S 5^{\circ} \text { do RICMS). }\end{array}$ & $\begin{array}{l}\text { A) Como o Ativo no } \\
\text { leasing operacional é } \\
\text { contabilizado como } \\
\text { Ativo do Arrendador e } \\
\text { não mais do } \\
\text { Arrendatário, logo, } \\
\text { poderia haver a } \\
\text { possibilidade de não se } \\
\text { reconhecer o crédito de } \\
\text { ICMS na Arrendatária } \\
\text { (que não tem um Ativo } \\
\text { Imobilizado). } \\
\text { B) Possível discussão } \\
\text { se haverá o Direito de } \\
\text { Crédito do ICMS destes } \\
\text { Ativos Imobilizados no } \\
\text { Arrendador, uma vez } \\
\text { que fisicamente o Ativo } \\
\text { Imobilizado não se } \\
\text { encontra no } \\
\text { estabelecimento (e sim, } \\
\text { de posse dos } \\
\text { arrendatários). }\end{array}$ \\
\hline
\end{tabular}




\begin{tabular}{|c|c|c|c|c|}
\hline$\underline{\mathbf{N}^{\mathbf{0}}}$ & Tema & $\begin{array}{l}\text { Normas Contábeis } \\
\underline{\underline{\text { (IFRS/CPC) }}}\end{array}$ & $\begin{array}{l}\text { Dispositivo do } \\
\underline{\text { RICMS/SP }}\end{array}$ & $\begin{array}{l}\text { Natureza do Risco } \\
\text { Fiscal }\end{array}$ \\
\hline & & $\begin{array}{l}\text { arrendatário, o item } 33 \\
\text { do CPC } 6 \text { dispõe que os } \\
\text { pagamentos da } \\
\text { prestação do } \\
\text { arrendamento mercantil } \\
\text { segundo um } \\
\text { arrendamento mercantil } \\
\text { operacional devem ser } \\
\text { reconhecidos como } \\
\text { despesa em base linear } \\
\text { durante o prazo do } \\
\text { arrendamento } \\
\text { mercantil, exceto se } \\
\text { outra base sistemática } \\
\text { for mais representativa } \\
\text { do modelo temporal do } \\
\text { benefício do usuário. } \\
\text { Sob a ótica do } \\
\text { arrendador, o ativo é de } \\
\text { propriedade dado } \\
\text { arrendador. Assim, } \\
\text { além da receita, a } \\
\text { arrendadora deve } \\
\text { reconhecer também a } \\
\text { depreciação do bem. }\end{array}$ & & \\
\hline 8 & $\begin{array}{l}\text { Reposiç } \\
\text { ão do } \\
\text { Ativo } \\
\text { Imobili } \\
\text { zado - } \\
\text { Quando } \\
\text { se } \\
\text { permite } \\
\text { o direito } \\
\text { ao } \\
\text { crédito } \\
\text { do } \\
\text { ICMS }\end{array}$ & $\begin{array}{l}\text { Ativo Imobilizado }- \\
\text { menciona o item } 8 \text { do } \\
\text { CPC-27: } \\
\text { "Sobressalentes, peças } \\
\text { de reposição, } \\
\text { ferramentas } r \\
\text { equipamentos de uso } \\
\text { interno são } \\
\text { classificados como } \\
\text { ativo imobilizado } \\
\text { quando a entidade } \\
\text { espera usá-los por mais } \\
\text { de um período. Da } \\
\text { mesma forma, se } \\
\text { puderem ser utilizados } \\
\text { somente em conexão } \\
\text { com itens do ativo } \\
\text { imobilizado, também } \\
\text { são contabilizados } \\
\text { comorativo } \\
\text { imobilizado". }\end{array}$ & $\begin{array}{l}\text { Decisão Normativa } \\
\text { CAT-1/2000: } \\
\text { a) Peças para conserto } \\
\text { (não geram direito ao } \\
\text { crédito) - Itens } 13 \text { e } 17 . \\
\text { b) Peças sobressalantes } \\
\text { do equipamento } \\
\text { depreciado (geram } \\
\text { direito ao crédito) e } \\
\text { Peças que acompanham } \\
\text { o Equipamento (geram } \\
\text { direito ao crédito): - } \\
\text { Itens } 14 \text { a } 16 .\end{array}$ & $\begin{array}{l}\text { A reposição de parte } \\
\text { dos ativos permite que } \\
\text { os contribuintes se } \\
\text { apropriem dos créditos } \\
\text { de ICMS? } \\
\text { Quais são os impactos } \\
\text { econômicos norma } \\
\text { tributários da norion } \\
\text { contábil (CPC) relativo } \\
\text { ao reconhecimento do } \\
\text { Ativo Imobilizado? } \\
\text { Há um risco de falta de } \\
\text { segurança jurídica e } \\
\text { divergências entre o } \\
\text { Fisco e o contribuinte } \\
\text { de quando a reposição } \\
\text { do ativo imobilizado } \\
\text { pode gerar crédito do } \\
\text { ICMS. }\end{array}$ \\
\hline 9 & Prazo & Ativo Imobilizado - & Artigo $61, \quad \S \quad 10 \quad$ do & A escolha do método de \\
\hline
\end{tabular}




\begin{tabular}{|c|c|c|c|c|}
\hline$\underline{N^{0}}$ & Tema & $\begin{array}{l}\text { Normas Contábeis } \\
\text { (IFRS/CPC) }\end{array}$ & $\frac{\text { Dispositivo do }}{\underline{\text { RICMS/SP }}}$ & $\begin{array}{l}\text { Natureza do Risco } \\
\text { Fiscal }\end{array}$ \\
\hline & $\begin{array}{l}\text { para o } \\
\text { Credita } \\
\text { mento } \\
\frac{\text { do }}{\text { ICMS }} \\
\underline{\underline{\text { do }}} \\
\text { Ativo } \\
\underline{\text { Imobili }} \\
\underline{\text { zado }}\end{array}$ & $\begin{array}{l}\text { CPC } 27 \text { - Itens } 55 \text { e } 60 \text { : } \\
\text { "55. A depreciação do } \\
\text { ativo se inicia quando } \\
\text { este está disponível } \\
\text { para uso, ou seja, } \\
\text { quando está no local e } \\
\text { em condição de } \\
\text { funcionamento na } \\
\text { forma pretendida pela } \\
\text { administração." } \\
\text { "60. O método de } \\
\text { depreciação utilizado } \\
\text { reflete o padrão de } \\
\text { consumo pela entidade } \\
\text { dos benefícios } \\
\text { economicos futuros." }\end{array}$ & 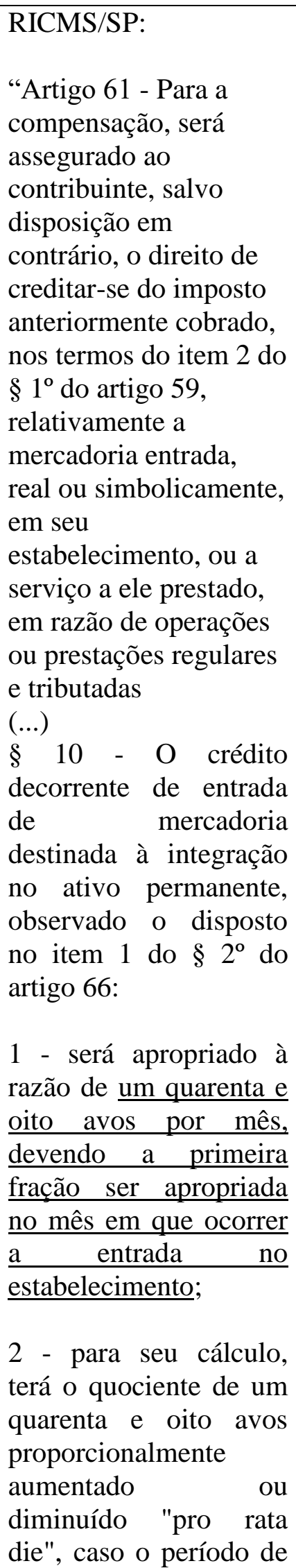 & $\begin{array}{l}\text { depreciação do Ativo } \\
\text { Imobilizado influencia } \\
\text { a base de creditamento } \\
\text { do ICMS? } \\
\text { E se uma determinada } \\
\text { máquina, por exemplo, } \\
\text { for depreciada em um } \\
\text { período menor que os } \\
48 \text { meses, por exemplo, } \\
\text { em } 2 \text { anos? Os créditos } \\
\text { do ICMS poderiam ser } \\
\text { excepcionalmente } \\
\text { apropriados em } 24 \\
\text { meses, neste caso? E se } \\
\text { não for possível a } \\
\text { apropriação em tempo } \\
\text { menor que } 48 \text { meses: } \\
\text { então devem ser } \\
\text { apropriados os créditos } \\
\text { em } 48 \text { meses, ainda que } \\
\text { a máquina esteja } \\
\text { sucateada ou seja } \\
\text { vendida como sucata } \\
\text { após o mês de número } \\
25^{\circ} \text { ? } \\
\text { Risco das empresas } \\
\text { com ativos } \\
\text { imobilizados com vida } \\
\text { útil menor que } 48 \\
\text { meses, em perder os } \\
\text { créditos do ICMS. }\end{array}$ \\
\hline
\end{tabular}




\begin{tabular}{|c|c|c|c|c|}
\hline$\underline{\mathbf{N}^{\mathbf{0}}}$ & Tema & $\begin{array}{l}\text { Normas Contábeis } \\
\text { (IFRS/CPC) }\end{array}$ & $\begin{array}{l}\text { Dispositivo do } \\
\underline{\text { RICMS/SP }}\end{array}$ & $\begin{array}{l}\text { Natureza do Risco } \\
\text { Fiscal }\end{array}$ \\
\hline & & & $\begin{array}{l}\text { apuração seja superior } \\
\text { ou inferior a um mês. } \\
\text { (...)" }\end{array}$ & \\
\hline 10 & $\begin{array}{l}\frac{\text { Início }}{\text { do }} \\
\frac{\text { Credita }}{\text { mento }} \\
\underline{\text { do }} \\
\frac{\text { ICMS }}{\text { do }} \\
\underline{\text { Ativo }} \\
\underline{\text { Imobili }} \\
\underline{\text { zado }}\end{array}$ & 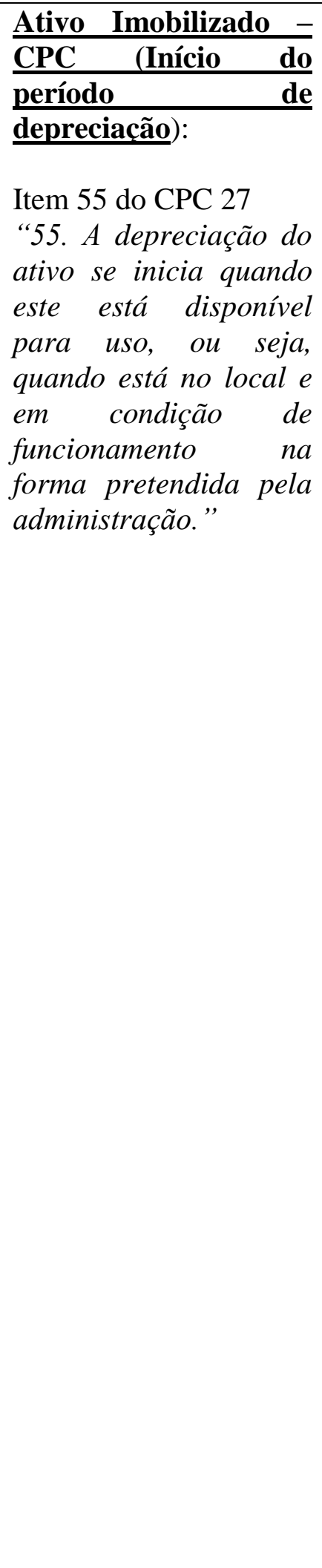 & 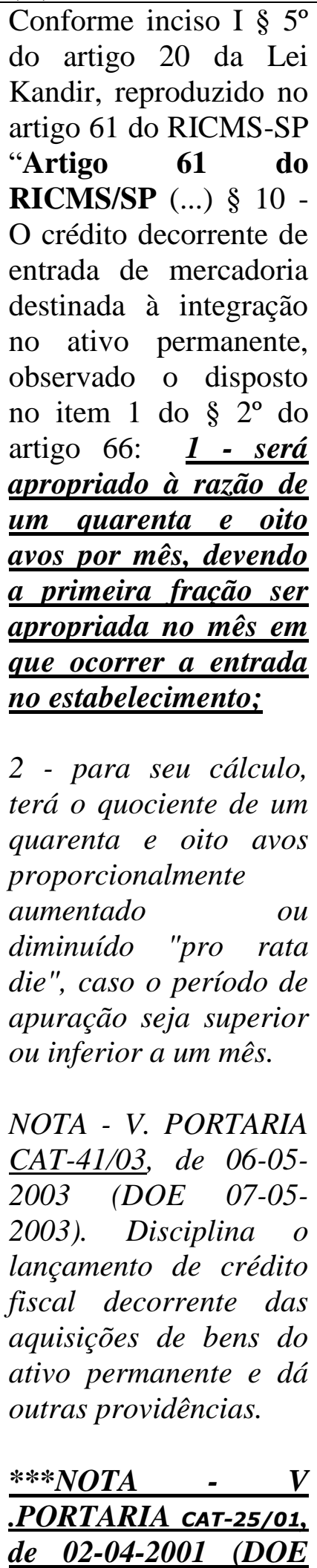 & $\begin{array}{l}\text { Há dúvidas quanto ao } \\
\text { momento mais } \\
\text { adequado para se iniciar } \\
\text { o creditamento do } \\
\text { Ativo Imobilizado. } \\
\text { Quando se inicia o } \\
\text { creditamento do ICMS } \\
\text { sobre o Ativo } \\
\text { Imobilizado: } \\
\text { a) Quando o mesmo é } \\
\text { adquirido? } \\
\text { Ou, } \\
\text { b) Quando o mesmo } \\
\text { entra em uso, no caso } \\
\text { de haver um período de } \\
\text { inatividade da máquina } \\
\text { (período } \\
\text { operacional)? }\end{array}$ \\
\hline
\end{tabular}




\begin{tabular}{|c|c|c|c|c|}
\hline$\underline{\mathbf{N}^{\mathbf{0}}}$ & Tema & $\begin{array}{l}\text { Normas Contábeis } \\
\text { (IFRS/CPC) }\end{array}$ & $\begin{array}{l}\text { Dispositivo do } \\
\text { RICMS/SP }\end{array}$ & $\begin{array}{l}\text { Natureza do Risco } \\
\text { Fiscal }\end{array}$ \\
\hline & & & 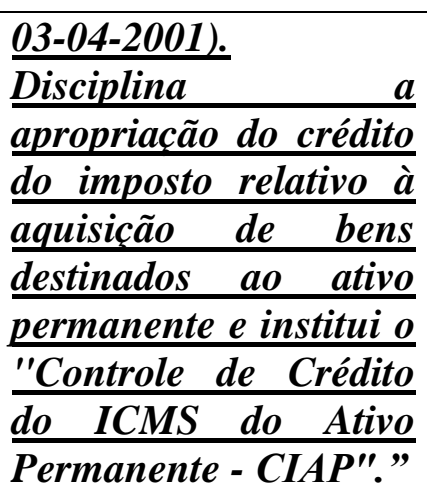 & \\
\hline 11 & $\begin{array}{l}\text { Ativo } \\
\text { Imobili } \\
\text { zado } \\
\text { que } \\
\text { esteja } \\
\text { fora do } \\
\text { estabele } \\
\text { cimento } \\
\text { (em } \\
\text { poder } \\
\text { de } \\
\text { terceiro } \\
\text { s) }\end{array}$ & $\begin{array}{l}\text { Conceito } \\
\text { Imobilizado (para uso } \\
\text { na } \\
\text { produção/fornecimento } \\
\text { de mercadorias e } \\
\text { serviços). } \\
\text { Com base no } 6 \text { do CPC } \\
27 .\end{array}$ & $\begin{array}{l}\text { Noção Fiscal de que o } \\
\text { Ativo Imobilizado deve } \\
\text { estar no } \\
\text { Estabelecimento. } \\
\text { Idéia que é reforçada } \\
\text { pelo dispositivo do } \\
\text { Estorno nas Saídas } \\
\text { Não-Tributadas. } \\
\text { Lei Kandir - artigo 20, } \\
\$ 5^{\circ}\end{array}$ & $\begin{array}{l}\text { O Ativo Imobilizado } \\
\text { para dar créditos do } \\
\text { ICMS (1/48 avos ao } \\
\text { mês) deve estar } \\
\text { fisicamente } \\
\text { estabelecimento } \\
\text { relacionado } \\
\text { produção/comercializaç } \\
\text { ão de mercadorias } \\
\text { tributadas? } \\
\text { Há o risco (dúvida por } \\
\text { parte do Fisco e do } \\
\text { Contribuinte) se os } \\
\text { ativos imobilizados que } \\
\text { estejam com parceiros } \\
\text { comerciais da empresa } \\
\text { confiram ou não crédito } \\
\text { do ICMS (por exemplo: } \\
\text { no caso das geladeiras } \\
\text { de sorvete ou de cerveja } \\
\text { que estejam cedidos } \\
\text { para os comerciantes } \\
\text { exclusivos mas sobre o } \\
\text { controle da indústria). }\end{array}$ \\
\hline 12 & $\begin{array}{l}\frac{\text { Crédito }}{\text { de }} \\
\text { Ativo } \\
\text { Imobili } \\
\frac{\text { zado }}{\text { para }} \\
\frac{\text { constru }}{\text { cão de }} \\
\frac{\text { um }}{\text { bem }} \\
\text { imóvel }\end{array}$ & $\begin{array}{l}\begin{array}{l}\text { Conceito } \\
\text { Imobilizado } \\
\text { bens imóveis). }\end{array} \\
\text { (inclui } \\
\text { Com base no } 6 \text { do CPC } \\
27 .\end{array}$ & $\begin{array}{l}\text { Não há crédito de } \\
\text { ICMS para bens } \\
\text { imóveis. } \\
\text { CF } \\
\text { específica dos imóveis) } \\
\text { e Decisão Normativa } \\
\text { CAT 2/2000. }\end{array}$ & $\begin{array}{l}\text { Risco dos Contribuintes } \\
\text { pleitearem o crédito } \\
\text { sobre bens imóveis. } \\
\text { Risco que já existia no } \\
\text { normativo contábil } \\
\text { anterior. }\end{array}$ \\
\hline 13 & $\begin{array}{l}\text { Ativo } \\
\text { Imobili }\end{array}$ & $\begin{array}{l}\text { Conceito de } \\
\text { Imobilizado (inclui }\end{array}$ & $\begin{array}{l}\text { Não Incidência do } \\
\text { ICMS: empréstimo ou }\end{array}$ & $\begin{array}{l}\text { Um dos problemas nos } \\
\text { contratos de locação, }\end{array}$ \\
\hline
\end{tabular}




\begin{tabular}{|c|c|c|c|c|}
\hline$\underline{\mathrm{N}^{\circ}}$ & Tema & $\begin{array}{l}\text { Normas Contábeis } \\
\text { (IFRS/CPC) }\end{array}$ & $\frac{\text { Dispositivo do }}{\underline{\text { RICMS/SP }}}$ & $\begin{array}{l}\text { Natureza do Risco } \\
\underline{\text { Fiscal }}\end{array}$ \\
\hline & $\begin{array}{l}\text { zado - } \\
\text { Descar } \\
\text { acteriza } \\
\text { cão da } \\
\text { Locacãa } \\
\text { o, } \\
\text { Aluguel } \\
2 \text { Comod } \\
\text { ato e } \\
\text { Figuras } \\
\underline{\text { Análog }} \\
\underline{\text { as. }}\end{array}$ & $\begin{array}{l}\text { Receitas - (CPC 30): } \\
\text { Transferência ao } \\
\text { comprador dos riscos e } \\
\text { benefício } \\
\text { Devem ser } \\
\text { contabilizados como } \\
\text { Ativos dos } \\
\text { Adquirentes! } \\
\text { Receitas - CPC } 30 \\
\text { (Venda de Bens - } \\
\text { reconhecimento da } \\
\text { Receita): } \\
\text { "14. A receita } \\
\text { proveniente da venda } \\
\text { de bens deve ser } \\
\text { reconhecida quando } \\
\text { forem satisfeitas todas } \\
\text { as seguintes condições: } \\
\text { (a) a entidade tenha } \\
\text { transferido para o } \\
\text { comprador os riscos e } \\
\text { benefícios mais } \\
\text { significativos inerentes } \\
\text { à propriedade dos bens; } \\
\text { (b) a entidade não } \\
\text { mantenha envolvimento } \\
\text { continuado na gestão } \\
\text { dos bens vendidos em } \\
\text { grau normalmente } \\
\text { associado à propriedade } \\
\text { nem efetivo controle de } \\
\text { tais bens; } \\
\text { (c) o valor da receita } \\
\text { possa ser } \\
\text { confiavelmente } \\
\text { mensurado; } \\
\text { (d) for provável que os } \\
\text { benefícios econômicos } \\
\text { associados à transação } \\
\text { fluirão para a entidade; } \\
\text { e } \\
\text { (e) as despesas } \\
\text { incorridas ou a serem }\end{array}$ & 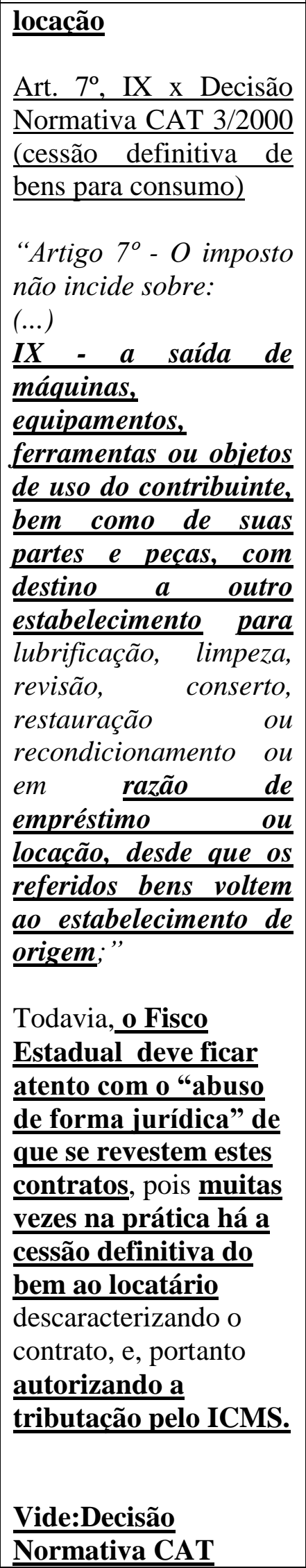 & $\begin{array}{l}\text { aluguel, comodato e } \\
\text { figs. jurídicas análogas } \\
\text { é que em "tese" não } \\
\text { haveria a tributação } \\
\text { pelo ICMS (não- } \\
\text { incidência), nem pelo } \\
\text { ISS. } \\
\text { Todavia, deve o Fisco } \\
\text { Estadual atentar p/ o } \\
\text { "abuso de forma } \\
\text { jurídica", pois muitas } \\
\text { vezes há a cessão } \\
\text { definitiva do bem ao } \\
\text { locatário o } \\
\text { descaracterizando } \\
\text { contrato, e, autorizando } \\
\text { a tributação pelo ICMS. } \\
\text { Notar, adicionalmente, } \\
\text { que a transferência ao } \\
\text { comprador dos riscos e } \\
\text { benefício pode implicar } \\
\text { no reconhecimento de } \\
\text { receita de vendas (CPC } \\
\text { 30). }\end{array}$ \\
\hline
\end{tabular}




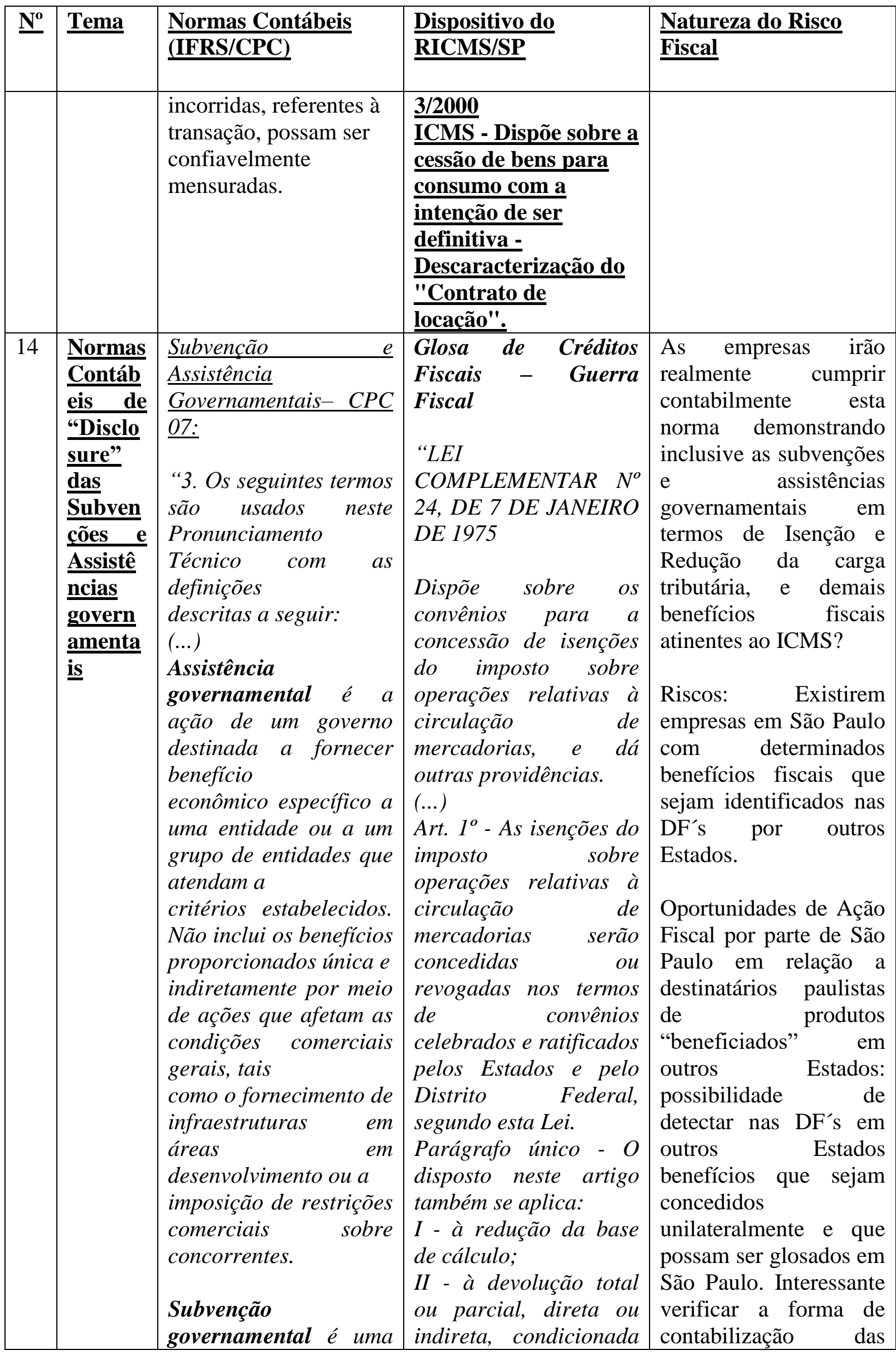




\begin{tabular}{|c|c|c|c|c|}
\hline$\underline{\mathrm{N}^{\circ}}$ & Tema & $\begin{array}{l}\text { Normas Contábeis } \\
\text { (IFRS/CPC) }\end{array}$ & $\frac{\text { Dispositivo do }}{\underline{\text { RICMS/SP }}}$ & $\begin{array}{l}\text { Natureza do Risco } \\
\text { Fiscal }\end{array}$ \\
\hline & & $\begin{array}{l}\text { assistência } \\
\text { governamental } \\
\text { geralmente na forma } \\
\text { de contribuição de } \\
\text { natureza pecuniária, } \\
\text { mas não só restrita a } \\
\text { ela, concedida a uma } \\
\text { entidade normalmente } \\
\text { em troca do } \\
\text { cumprimento passado } \\
\text { ou futuro de certas } \\
\text { condições relacionadas } \\
\text { às atividades } \\
\text { operacionais } \\
\text { entidade. Não são } \\
\text { subvenções } \\
\text { governamentais } \\
\text { aquelas que não podem } \\
\text { ser razoavelmente } \\
\text { quantificadas } \\
\text { dinheiro em } \\
\text { transações com } \\
\text { governo que não podem } \\
\text { ser } \\
\text { distinguidas } \\
\text { transações comerciais } \\
\text { normais da entidade. } \\
\text { (...)" }\end{array}$ & 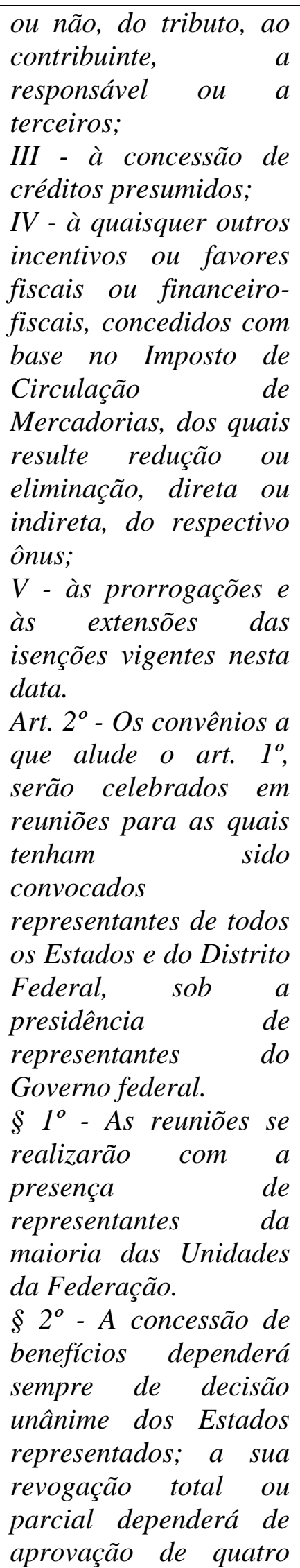 & $\begin{array}{l}\text { subvenções } \\
\text { governamentais, } \\
\text { especialmente no } \\
\text { Balanço de empresas de } \\
\text { fora do Estado de São } \\
\text { Paulo ("Guerra } \\
\text { Fiscal"). }\end{array}$ \\
\hline
\end{tabular}




\begin{tabular}{|c|c|c|c|c|}
\hline$\underline{\mathbf{N}^{\circ}}$ & Tema & $\begin{array}{l}\text { Normas Contábeis } \\
\underline{\text { (IFRS/CPC })}\end{array}$ & $\begin{array}{l}\text { Dispositivo do } \\
\underline{\text { RICMS/SP }}\end{array}$ & $\begin{array}{l}\text { Natureza do Risco } \\
\underline{\text { Fiscal }}\end{array}$ \\
\hline & & & 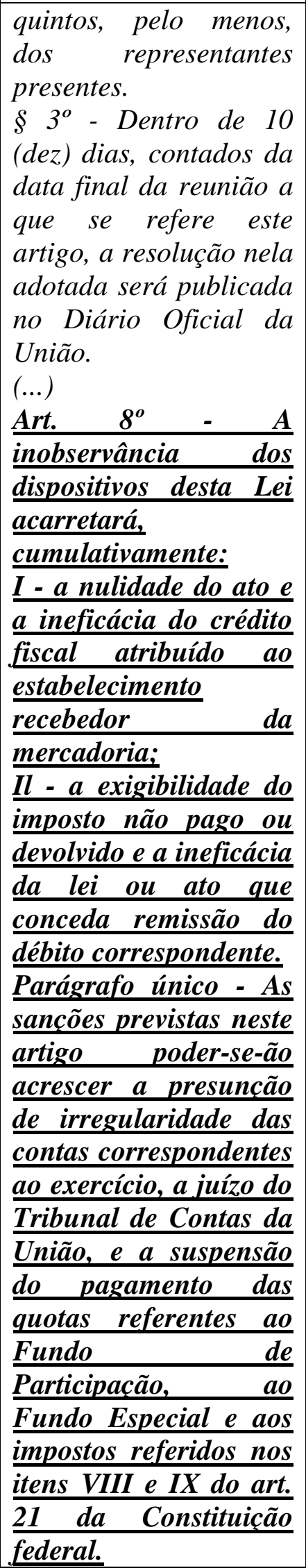 & \\
\hline
\end{tabular}




\begin{tabular}{|c|c|c|c|c|}
\hline$\underline{\mathrm{N}^{\circ}}$ & Tema & $\begin{array}{l}\text { Normas Contábeis } \\
\text { (IFRS/CPC) }\end{array}$ & $\frac{\text { Dispositivo do }}{\underline{\text { RICMS/SP }}}$ & $\begin{array}{l}\text { Natureza do Risco } \\
\underline{\text { Fiscal }}\end{array}$ \\
\hline & & & $(\ldots)^{\prime \prime}$ & \\
\hline 15 & $\begin{array}{l}\text { Reconh } \\
\text { eciment } \\
\text { o } \\
\text { Contáb } \\
\text { il da } \\
\text { Receita } \\
\text { de } \\
\text { vendas } \\
\text { de } \\
\text { mercad } \\
\text { orias }\end{array}$ & 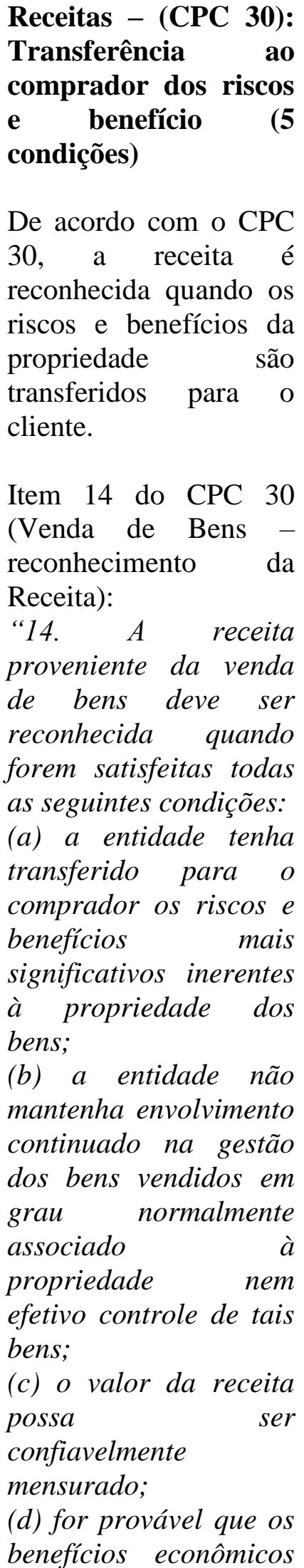 & 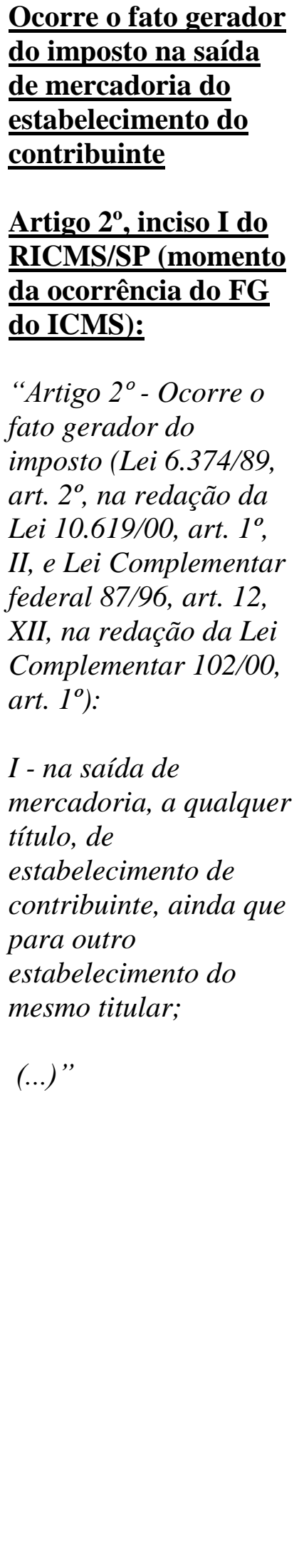 & $\begin{array}{l}\text { Dessincronização } r \\
\text { regime do } \\
\text { reconhecimento das } \\
\text { receitas, do momento } \\
\text { da venda ou da } \\
\text { prestação do serviço } \\
\text { (alinhado à emissão de } \\
\text { documentos fiscais). } \\
\text { Risco da Entidade } \\
\text { postergar o } \\
\text { reconhecimento das } \\
\text { Receitas pela } \\
\text { Contabilidade e Querer } \\
\text { também postergar o } \\
\text { ICMS. } \\
\text { Riscos em relação aos } \\
\text { Levantamentos Fiscais, } \\
\text { na medida em que o } \\
\text { contribuinte irá alegar } \\
\text { que há Receitas } \\
\text { Contábeis que ainda } \\
\text { não representam saída } \\
\text { de mercadorias ou } \\
\text { prestação de serviços. } \\
\text { - }\end{array}$ \\
\hline
\end{tabular}




\begin{tabular}{|c|c|c|c|c|}
\hline$\underline{\mathbf{N}^{\circ}}$ & $\underline{\text { Tema }}$ & $\begin{array}{l}\text { Normas Contábeis } \\
\underline{\text { (IFRS/CPC) }}\end{array}$ & $\begin{array}{l}\text { Dispositivo do } \\
\underline{\text { RICMS/SP }}\end{array}$ & $\begin{array}{l}\text { Natureza do Risco } \\
\text { Fiscal }\end{array}$ \\
\hline & & 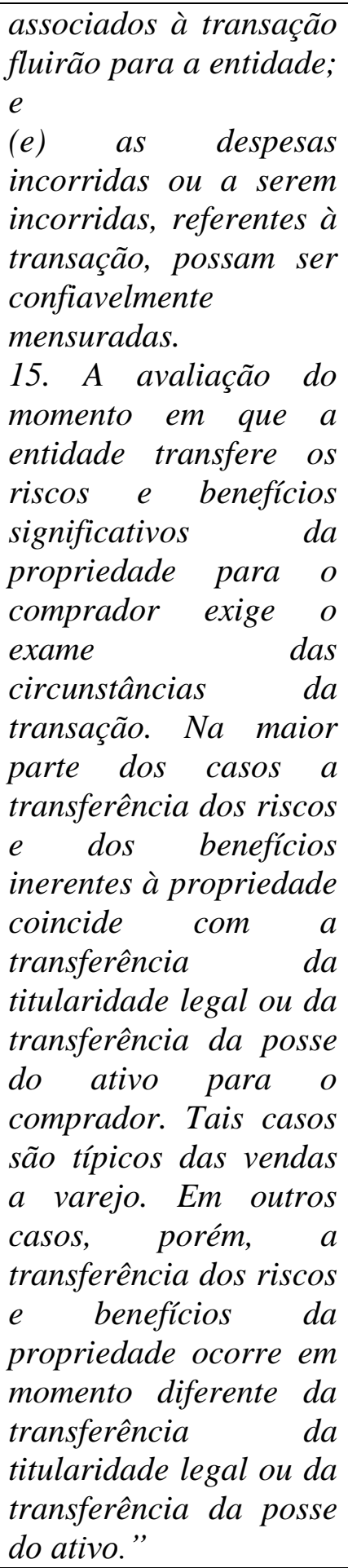 & & \\
\hline 16 & $\begin{array}{l}\text { Mensur } \\
\text { ação de } \\
\text { ativos } \\
\text { biológic } \\
\text { os. }\end{array}$ & $\begin{array}{l}\begin{array}{l}\text { Valoração } \\
\text { biológicos. }\end{array} \\
\text { Itens } 10 \text { a } 29 \text { do CPC } \\
29 . \\
\text { O CPC } 29 \text { estabelece o }\end{array}$ & 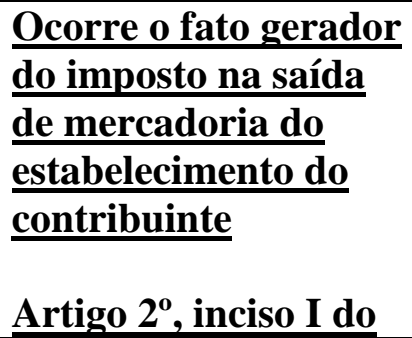 & $\begin{array}{l}\text { Aumento (ou redução) } \\
\text { do resultado contábil } \\
\text { apurado, decorrente do } \\
\text { ajuste a valor justo } \\
\text { efetuado contra o } \\
\text { resultado do exercício } \\
\text { (referente ao ano- }\end{array}$ \\
\hline
\end{tabular}




\begin{tabular}{|c|c|c|c|c|}
\hline$\underline{\mathbf{N}^{0}}$ & Tema & $\begin{array}{l}\text { Normas Contábeis } \\
\text { (IFRS/CPC) }\end{array}$ & $\begin{array}{l}\text { Dispositivo do } \\
\underline{\text { RICMS/SP }}\end{array}$ & $\begin{array}{l}\text { Natureza do Risco } \\
\text { Fiscal }\end{array}$ \\
\hline & & $\begin{array}{l}\text { tratamento } \\
\text { para os ativos } \\
\text { biológicos, requerendo } \\
\text { a contabilização pelo } \\
\text { valor justo, desde o } \\
\text { reconhecimento inicial. } \\
\text { As variações são } \\
\text { receitas ou despesas na } \\
\text { demonstração do } \\
\text { resultado do período. }\end{array}$ & $\begin{array}{l}\text { RICMS/SP (momento } \\
\text { da ocorrência do FG } \\
\text { do ICMS): } \\
\text { “Artigo } 2^{\circ} \text { - Ocorre o } \\
\text { fato gerador do } \\
\text { imposto (Lei } 6.374 / 89, \\
\text { art. } 2^{\circ} \text {, na redação da } \\
\text { Lei } 10.619 / 00, \text { art. } 1^{\circ} \text {, } \\
\text { II, e Lei Complementar } \\
\text { federal } 87 / 96, \text { art. } 12, \\
\text { XII, na redação da Lei } \\
\text { Complementar 102/00, } \\
\left.\text { art. } 1^{\circ}\right): \\
\text { I- na saída de } \\
\text { mercadoria, a qualquer } \\
\text { título, de } \\
\text { estabelecimento de } \\
\text { contribuinte, ainda que } \\
\text { para outro } \\
\text { estabelecimento do } \\
\text { mesmo titular; } \\
\text { (...)" }\end{array}$ & $\begin{array}{l}\text { calendário } 2010 \text { em } \\
\text { diante). As variações } \\
\text { são receitas ou despesas } \\
\text { na demonstração do } \\
\text { resultado do período. } \\
\text { Nessa situação há a } \\
\text { antecipação de receitas } \\
\text { para a PJ. A tributação } \\
\text { deve acompanhar o } \\
\text { momento de prestação } \\
\text { dos serviços ou a saída } \\
\text { da mercadoria? } \\
\text { A tributação do ICMS } \\
\text { deve-se dar no } \\
\text { momento da alienação } \\
\text { do produto agrícola ou } \\
\text { agroindustrial, com } \\
\text { eliminação dos efeitos } \\
\text { apontados. } \\
\text { Mesmos Riscos } \\
\text { mencionados no item } 6 \\
\text { (Reconhecimento } \\
\text { Contábil da Receita). }\end{array}$ \\
\hline
\end{tabular}

